\title{
Ground-Water Resources of Sheridan County, Wyoming
}

GEOLOGICAL SURVEY WATER-SUPPLY PAPER 1807

Prepared in cooperation with the Wyoming State Engineer

0. S. GEOLCICAL SURVE.

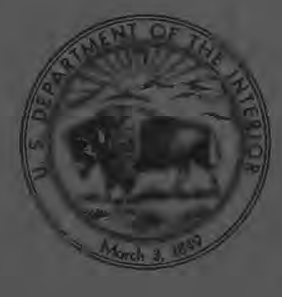
WATER RESOIIRCES OIVISION

AUG 151965 


\section{Ground-Water Resources of}

\section{Sheridan County, Wyoming}

By MARLIN E. LOWRY and T. RAY CUMMINGS

GEOLOGICAL SURVEY WATER-SUPPLY PAPER 1807

Prepared in cooperation with the Wyoming State Engineer

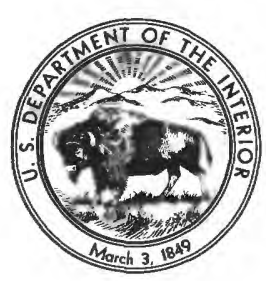


UNITED STATES DEPARTMENT OF THE INTERIOR

STEWART L. UDALL, Secretary

GEOLOGICAL SURVEY

William T. Pecora, Director

Library of Congress catalog-card No. GS 66-172

For sale by the Superintendent of Documents, U.S. Government Printing Office Washington, D.C. 20402 


\section{CONTENTS}

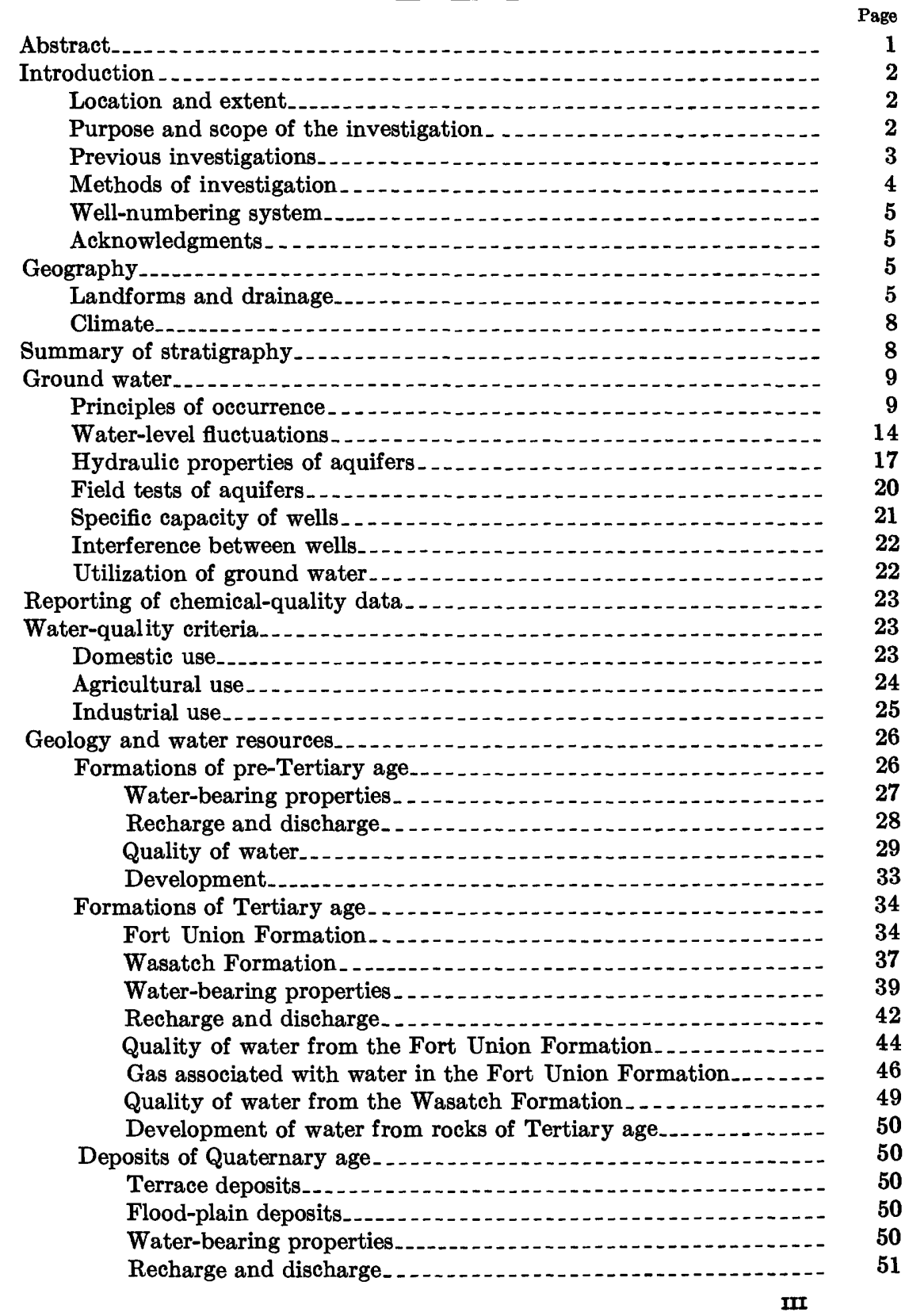


Geology and water resources-Continued

Deposits of Quaternary age-Continued

Quality of water.....

Development._... 53

References cited... 54

Basic data... 57

Index

\section{ILLUSTRATIONS}

Page

Plate 1. Geologic map of Sheridan County, Wyo ......... In pocket

FiguRe 1. Index map of Wyoming 3

2. Diagram showing well-numbering system

3. Photographs showing slump along Jackson Creek ......... 7

4. Graph showing precipitation at Sheridan, Wyo...... 9

5-8. Hydrographs of:

5. Three wells that penetrate the alluvium, and gage height of the Tongue River upstream from Dayton, Wyo

6. Three wells that penetrate formations of Tertiary age $\quad 16$

7. Three wells penetrating aquifers affected by irrigation

8. Observation well near discharging wells_........... 19

9. Photograph showing a cavern in the Madison Limestone . ... 27

10. Structure contour map of the top of the Cloverly Formation ... - 35

11. Diagram showing wells in the valley of Little Goose Creek_... 41

12. Photograph showing channel sandstone in the Fort Union Formation

13. Diagram showing correlation of coal beds in eastern Sheridan County, Wyo

14. Graph showing chemical characteristics of ground water.....

15. Cross section of a part of the Powder River valley, view downstream.

16. Cross section of the valleys of Prairie Dog Creek, Tongue River, and Dutch Creek, view downstream . .

\section{TABLES}

TABLE 1. Stratigraphic units and their water-bearing characteristics. -..--

2. Results of pumping tests . .

3. Reported specific capacity of wells in the Fort Union and Wasatch Formations

4. Chemical analyses of ground water in Sheridan County, Wyo.-

5. Quantity and quality of gas discharged with water from the

Fort Union Formation, Sheridan County, Wyo

6. Record of wells and springs in Sheridan County, Wyo

7. Logs of test holes, seismic shotholes, and wells. 


\title{
GROUND-WATER RESOURGES OF SHERIDAN COUNTY WYOMING
}

\author{
By Marlin E. Lowry and T. Ray Cummings
}

\begin{abstract}
Sheridan County is in the north-central part of Wyoming and is an area of about 2,500 square miles. The western part of the county is in the Bighorn Mountains, and the eastern part is in the Powder River structural basin. Principal streams are the Powder and Tongue Rivers, which are part of the Yellowstone River system. The climate is semiarid, and the mean annual precipitation at Sheridan is about 16 inches.

Rocks of Precambrian age are exposed in the central part of the Bighorn Mountains, and successively younger rocks are exposed eastward. Rocks of Tertiary age, which are the most widespread, are exposed throughout a large part of the Powder River structural basin. Deposits of Quaternary age underlie the flood plains and terraces along the larger streams, particularly in the western part of the basin.

Aquifers of pre-Tertiary age are exposed in the western part of the county, but they dip steeply and are deeply buried just a few miles east of their outcrop. Aquifers that might yield large supplies of water include the Bighorn Dolomite, Madison Limestone, Amsden Formation, and Tensleep Sandstone. The Flathead Sandstone, Sundance Formation, Morrison Formation, Cloverly Formation, Newcastle Sandstone, Frontier Formation, Parkman Sandstone, Bearpaw Shale, and Lance Formation may yield small or, under favorable conditions, moderate supplies of water.

Few wells tap aquifers of pre-Tertiary age, and these are restricted to the outcrop area. The meager data available indicate that the water from the Lance Formation, Bearpaw Shale, Parkman Sandstone, Tensleep Sandstone and Amsden Formation, and Flathead Standstone is of suitable quality for domestic or stock purposes, and that water from the Tensleep Sandstone and Amsden Formation and the Flathead Sandstone is of good quality for irrigation. Samples could not be obtained from other aquifers of pre-Tertiary age; so the quality of water in these aquifers could not be determined.

Adequate supplies of ground water for stock or domestic use can be developed throughout much of the report area from the Fort Union and Wasatch Formations of Tertiary age; larger supplies might be obtained from the coarse-grained sandstone facies of the Wasatch Formation near Moncreiffe Ridge. Four aquifer tests were made at wells tapping formations of Tertiary age, and the coefficients of permeability determined ranged from 2.5 to 7.9 gallons per day per square foot. The depths to which wells must be drilled to penetrate an aquifer differ within relatively short distances because of the lenticularity of the aquifers.
\end{abstract}


Water in aquifers of Tertiary age may occur under water-table, artesian, or a combination of artesian and gas-lift conditions.

Water from the Fort Union is usable for domestic purposes, but the iron and dissolved-solids content impair the quality at some localities. Water from the Fort Union Formation is not recommended for irrigation because of sodium and bicarbonate content. The water is regarded as good to fair for stock use. Water from the Wasatch Formation generally contains dissolved solids in excess of the suggested domestic standards, but this water is usable in the absence of other supplies. The development of irrigation supplies from the Wasatch Formation may be possible in some areas, but the water quality should be carefully checked. Water of good to very poor quality for stock supplies is obtained, depending upon the location. Hydrogen sulfide, commonly present in water of the Fort Union and Wasatch Formations, becomes an objectionable characteristic when the water is used for human consumption.

Deposits of Quaternary age generally yield small to moderate supplies of water to wells. Two pumping tests were conducted, and the coefficients of permeability of the aquifers tested were 380 and 1,100 gallons per day per square foot. Usable supplies of ground water can be developed from the deposits of Quaternary age, principally along the valleys of perennial streams that head in the mountains and from terraces in the western part of the county ; the thickest known deposit of alluvium is in the valley of Dutch Creek, which heads in the Powder River structural basin. Water from the alluvium is usable as a stock supply but has objectionable characteristics for domestic and irrigation use.

Recharge to ground-water reservoirs is from precipitation and seepage from streams and irrigation. Recharge conditions are generally better in the western part of the basin, where precipitation is greater and where there are more perennial streams and irrigated lands. Discharge from the ground-water reservoirs is by seepage to streams, evaporation, transpiration, and by wells and springs.

\section{INTRODUCTION}

\section{LOCATION AND EXTENT}

Sheridan County, Wyo., which is in the north-central part of the State, is an area of approximately 2,500 square miles. It is bounded on the north by Montana, and on the south, east, and west by the Wyoming Counties of Johnson, Campbell, and Big Horn, respectively. The west boundary is also the drainage divide of the Bighorn Mountains.

The area of this project and other areas in the State for which information on ground water is available, or where work is in progress, are shown in figure 1.

\section{PURPOSE AND SCOPE OF THE INVESTIGATION}

The purpose of this investigation was to determine the occurrence, quality, and availability of ground water, the character and extent of the water-bearing formations, and the possibilities of developing water supplies for domestic, stock, irrigation, industrial, and municipal uses. 


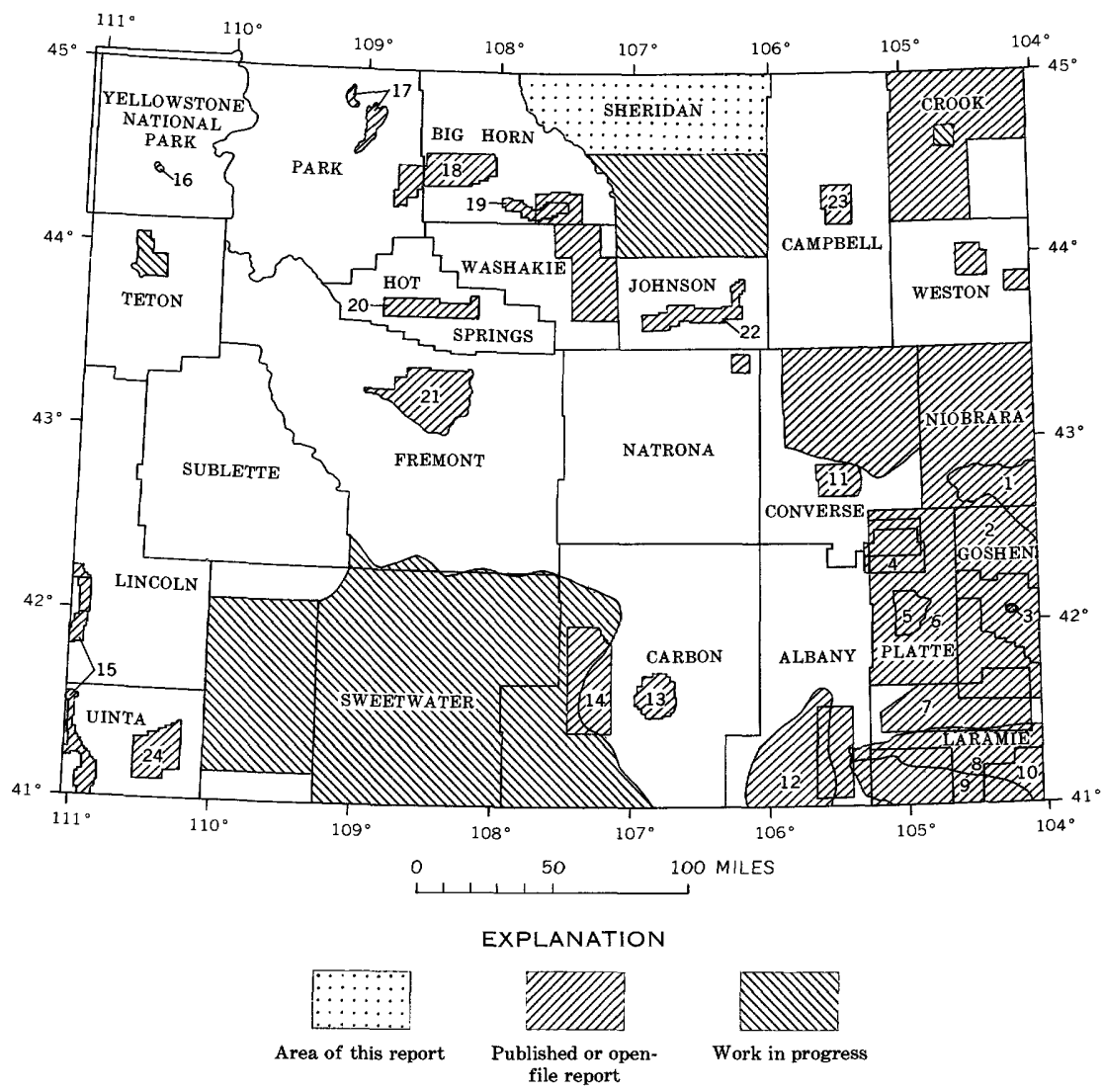

FIgURE 1.-Report area and other areas in which ground-water investigations have been made or where ground-water work is in progress.

The investigation was started in the fall of 1959 as part of the program of the U.S. Geological Survey in cooperation with the office of the Wyoming State Engineer. The ground-water study was under the supervision of E. D. Gordon, district geologist of the Geological Survey for Wyoming. The quality-of-water studies were made under the supervision of T. F. Hanly, district engineer of the Geological Survey for Wyoming.

\section{PREVIOUS INVESTIGATIONS}

The geology and ground-water conditions in Sheridan County were first described in a reconnaissance study by Darton (1905). Warner (1946) described ground-water conditions in the vicinity of Ranchester, Wyo., in an open-file report of the Geological Survey. Numerous geologic investigations made in the area proved most useful 
in the present investigation, and these are cited elsewhere in this report.

Reports for numbered areas have been published by the U.S. Geological Survey as water-supply papers (WSP) or circulars (Cir). (See list below.) Reports for other areas have been released as open-file reports of the U.S. Geological Survey.

\begin{tabular}{|c|c|c|c|}
\hline $\begin{array}{l}\text { Number in } \\
\text { fig. } 1\end{array}$ & U.S. Geol. Survey pub. & Author & Year \\
\hline 1 & WSP 1368_... & Bradley, Edward & 1956 \\
\hline \multirow[t]{2}{*}{2} & WSP 1377 & Rapp, J. R., and others & 1957 \\
\hline & WSP 70_....... & Adams, G. I. & 1902 \\
\hline 3 & Cir $238 \ldots \ldots$ & Visher, F. N., and Babcock, H. M.... & 1953 \\
\hline 4 & Cir $163 \ldots \ldots$ & Rapp, J. R., and Babcock, H. M.... & 1953 \\
\hline 5 & Cir $70 \ldots \ldots$ & Littleton, R. T & 1950 \\
\hline 6 & WSP 1490 & Babcock, H. M., and Morris, D. A. & 1960 \\
\hline 7 & Cir $162 \ldots \ldots$ & Babcock, H. M., and Rapp, J. R. & 1952 \\
\hline \multirow[t]{2}{*}{8} & WSP 1483 & Bjorkland, L. J. & 1959 \\
\hline & WSP $425-B_{\ldots} \ldots$ & Meinzer, O. E & 1919 \\
\hline 9 & WSP 1367 & Babcock, H. M., and Bjorkland, L. J.- & 1956 \\
\hline 10 & WSP $1140 \ldots \ldots$ & Rapp, J. R., and others. & 1953 \\
\hline 11 & Cir 243 & Rapp., J. R. & 1953 \\
\hline 12 & Cir $80 \ldots \ldots$ & Littleton, R. T & 1950 \\
\hline 13 & Cir $188 \ldots \ldots$ & Visher, F. N. & 1953 \\
\hline 14 & WSP 1458 & Berry, D. W. & 1960 \\
\hline 15 & WSP $1539-V \ldots \ldots$ & Robinove, C. J., and Berry, D. W. & 1963 \\
\hline 16 & WSP 1475-F_.. & Gordon, E. D., and others & 1962 \\
\hline 17 & WSP 1418 & Swenson, F. A. & 1957 \\
\hline 18 & WSP 1596 & Robinove, C. J., and Langford, R. H & 1963 \\
\hline 19 & Cir $96 \ldots \ldots$ & Swenson, F. A., and Bach, W. K. & 1951 \\
\hline 20 & WSP 1519 & Berry, D. W., and Littleton, R. T & 1961 \\
\hline 21 & WSP 1375 & Morris D. A., and others & 1959 \\
\hline 22 & WSP $1360-E_{\ldots} \ldots$ & Kohout, G. A. & 1957 \\
\hline 23 & Cir $76 \ldots$ & Littleton, R. T & 1950 \\
\hline 24 & WSP $1669-E_{\ldots} \ldots$ & Robinove, C. J., and Cummings, T. R_ & 1963 \\
\hline
\end{tabular}

\section{METHODS OF INVESTIGATION}

A network of observation wells was established during the spring of 1960, and measurements were made monthly through October 1961. Of the records collected on wells and springs, only 301 were tabulated for use in this report; however, all the data available were used in the conclusions and general statements regarding ground water. Samples of ground water were analyzed in Geological Survey laboratories. Test holes were augered at three sites to determine thickness and physical character of alluvial deposits. Well locations were recorded on 
aerial photographs and transferred to a base map, adapted from the Sheridan County general highway map which had been prepared by the Wyoming Highway Department.

\section{WELL-NUMBERING SYSTEM}

Wells, springs, and test holes are numbered according to the Federal system of land subdivision. Each well number shows the location of the well by township, range, section, and location within the section (fig. 2).

The first numeral of a well number indicates the township; the second, the range; and the third, the section in which the well is located. Lowercase letters following each section number indicate the position of the well in that section. The first letter denotes the quarter section; the second letter, the quarter-quarter section; and the third letter, the quarter-quarter-quarter section (10 acre tract). The subdivisions of a section are lettered $a, b, c$, and $d$ in a counterclockwise direction, starting in the northeast quarter. If more than one well is listed in a 10-acre tract, consecutive numbers, starting with one, are added to the well numbers.

\section{ACKNOWLEDGMENTS}

The writers are indebted to many persons who contributed information and assistance. C. T. Reid and Carl Ritola furmished information on wells they had drilled in the area. Many other residents of Sheridan County supplied information regarding their wells and gave permission for various measurements and tests.

\section{GEOGRAPHY}

\section{LANDFORMS AND DRAINAGE}

Sheridan County lies within two topographic provinces: the Bighorn Mountains and the Powder River structural basin. In this report the boundary between the provinces is arbitrarily defined as the top of the Tensleep Sandstone of Pennsylvanian age. The Tensleep and older formations, which consist predominantly of resistant sandstone, limestone, and dolomite, constitute the flank of the mountains. Formations younger than the Tensleep, which are composed predominantly of shale and siltstone, have been eroded to a comparatively low surface in the basin.

Altitudes in the Powder River structural basin range from about 4,780 feet at the head of Buffalo Creek to about 3,460 feet where the Tongue River crosses the Montana State line. The highest point in the county is about 11,000 feet.

$793-27610-66-6-2$ 


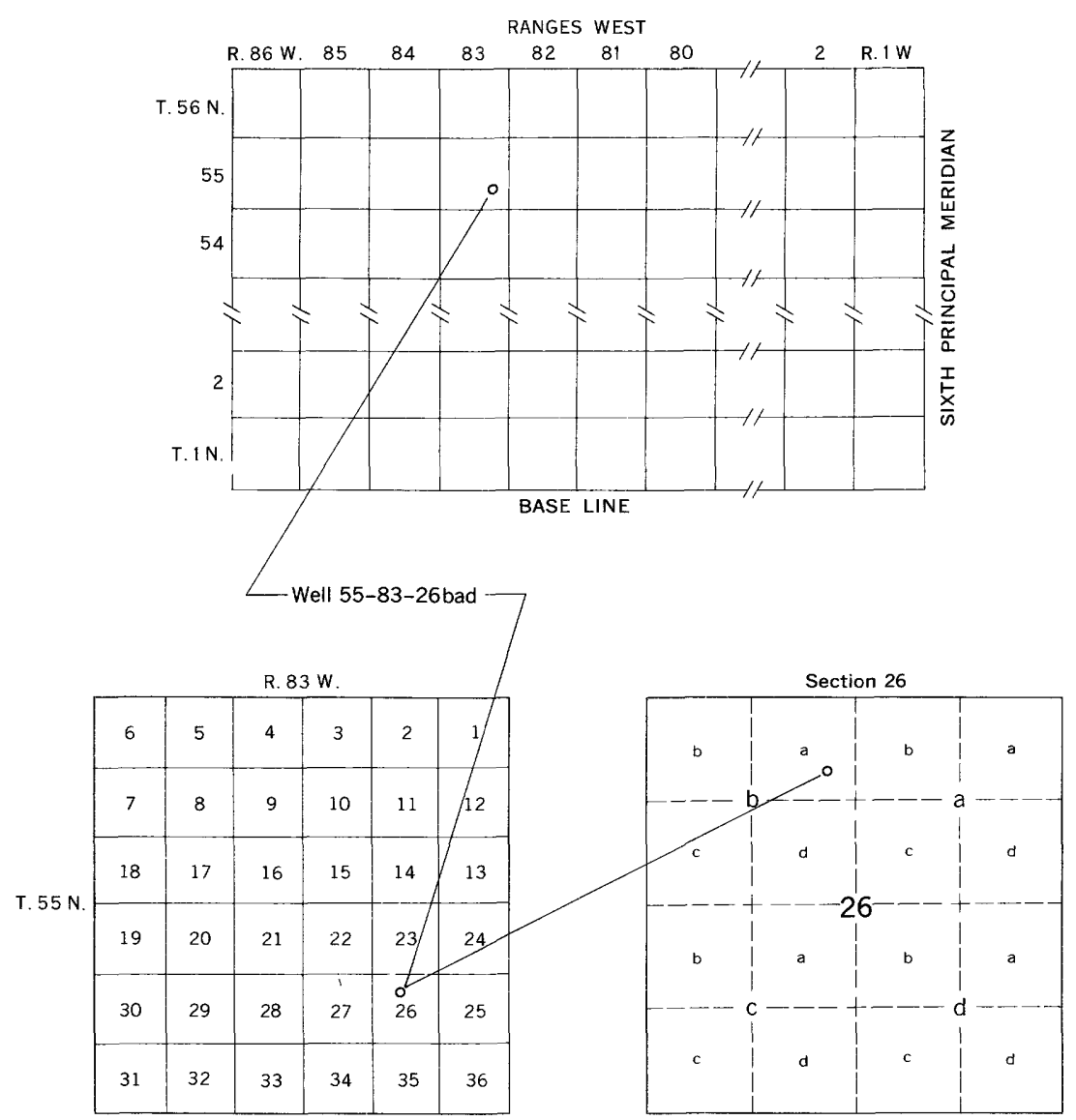

Figure 2.-Well-numbering system.

Numerous small streams separated by high ridges and divides dissect the basin. Red clinker (formed by burning coal) and sandstone cap the ridges and divides. Badlands have developed locally.

Land slumps are common in the western part of the basin, where precipitation is greater and irrigation is more common. The large slump shown in figure 3 is due in part to the disturbance of the equilibrium caused by the rechanneling of the creek into the toe of the slope, and in part by the irrigation of land above the slope.

Sheridan County is in the Yellowstone River drainage system and is drained by the Little Bighorn, Powder, and Tongue Rivers. The Little Bighorn River, a perennial stream, drains only about 190 square miles of the northern Bighorn Mountains. Its average flow at the 

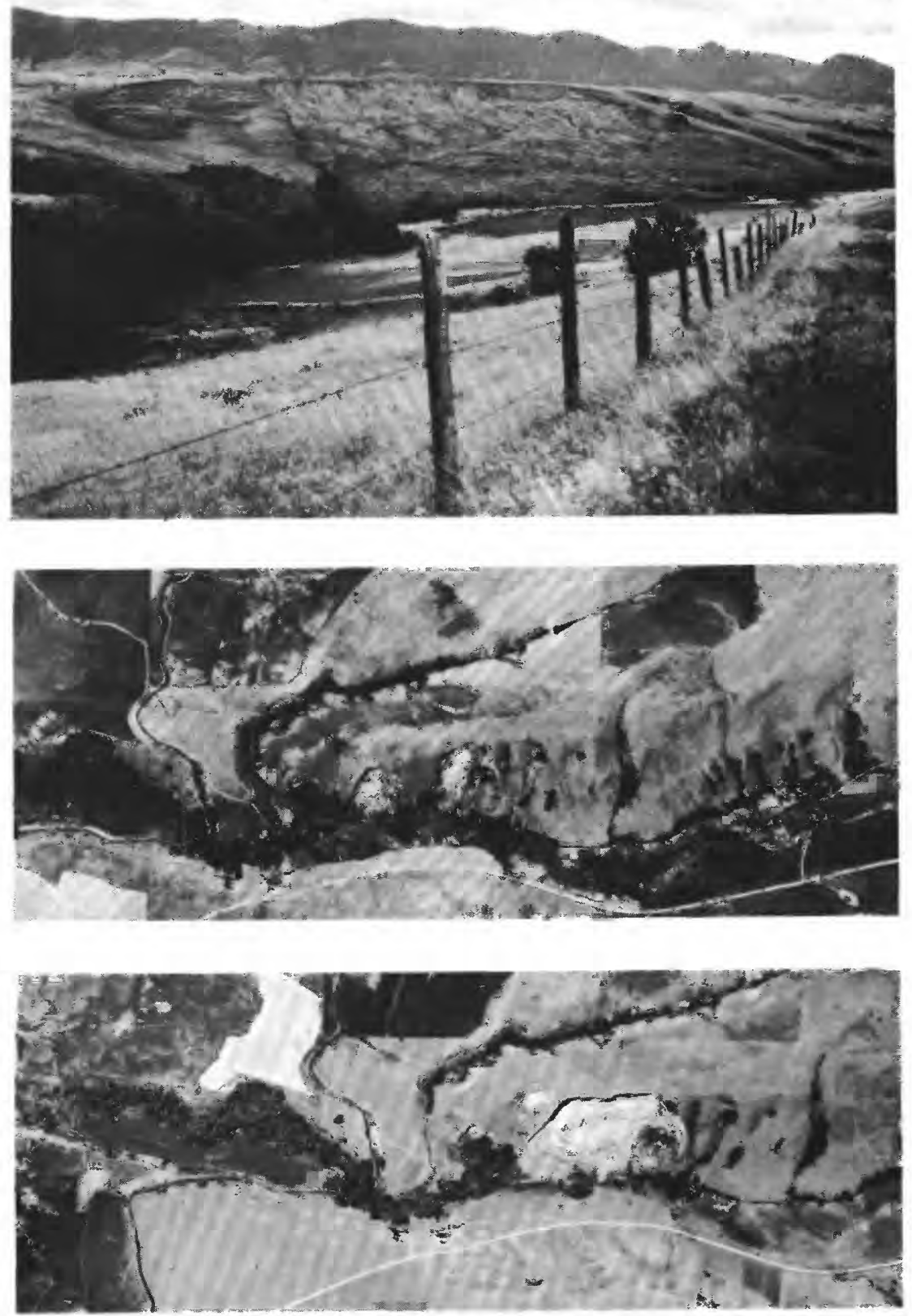

Figure 3.-Slump along Jackson Creek in sec. 6, T. 54 N., R. 84 W., and sec. 1 , T. 54 N., R. 85 W. Upper, Conditions of land slump in 1961; middle and lower, aerial photographs of same area in 1954 and 1958, respectively. Aerial photographs by U.S. Department of Agriculture. 
State line is 140 cfs (cubic feet per second) for 21 years of record (Hendricks, 1961, p. 199).

The Powder River, which flows close to and nearly parallels the east boundary of the county, drains the southern and eastern parts of the county. The average discharge at Arvada for 29 years of record is $257 \mathrm{cfs}$; a maximum flow of $100,000 \mathrm{cfs}$ occurred September 29, 1923 (Hendricks, 1961, p. 227). At times during most of the years of record, the Powder River has had no flow. Clear Creek, which heads in the Bighorn Mountains and is generally perennial, is the principal tributary of the Powder River in Sheridan County. The flow of the Powder River and its tributaries is affected by reservoirs and diversions for irrigation.

Most of Sheridan County is drained by the Tongue River. This river and its main tributaries head in the Bighorn Mountains and flow eastward to about the longitude of Sheridan and then flow northward out of the county. Average flow of the Tongue River near Dayton for 7 years of record is $10.3 \mathrm{cfs}$ (Hendricks, 1961, p. 207). The average discharge of Goose Creek, the principal tributary to the Tongue River below Dayton, for 19 years of record is 179 cfs (Hendricks, 1961, p. 214).

\section{CLIMATE}

Sheridan County is semiarid and has a wide temperature range. The mountains and adjacent areas receive the greatest amounts of precipitation because of frequent orographic storms in the spring and summer. East of the mountains the precipitation decreases in amount from 19 inches at Parkman and 16 inches at Sheridan to less than 14 inches at Clearmont and Arvada. Forty-four percent of the moisture comes during April, May, and June. The driest season is winter, when only 13 percent of the total precipitation occurs. The total amount of precipitation varies considerably from year to year. A minimum of 8.23 inches was recorded at the Sheridan weather station in 1960, and the maximum recorded at that station was 29.79 inches in 1923. Figure 4 shows the annual, normal, and 3-year moving-mean precipitation at Sheridan, Wyo.

\section{SUMMARY OF STRATIGRAPHY}

Approximately nine-tenths of Sheridan County is underlain by sedimentary rocks that range in age from Cambrian to Recent. Igneous rocks of Precambrian age are exposed in the Bighorn Mountains (pl. 1).

A summary of the stratigraphic units and their water-bearing characteristics is given in table 1; more detailed information on some of these formations, their water-bearing properties, and the chemical 


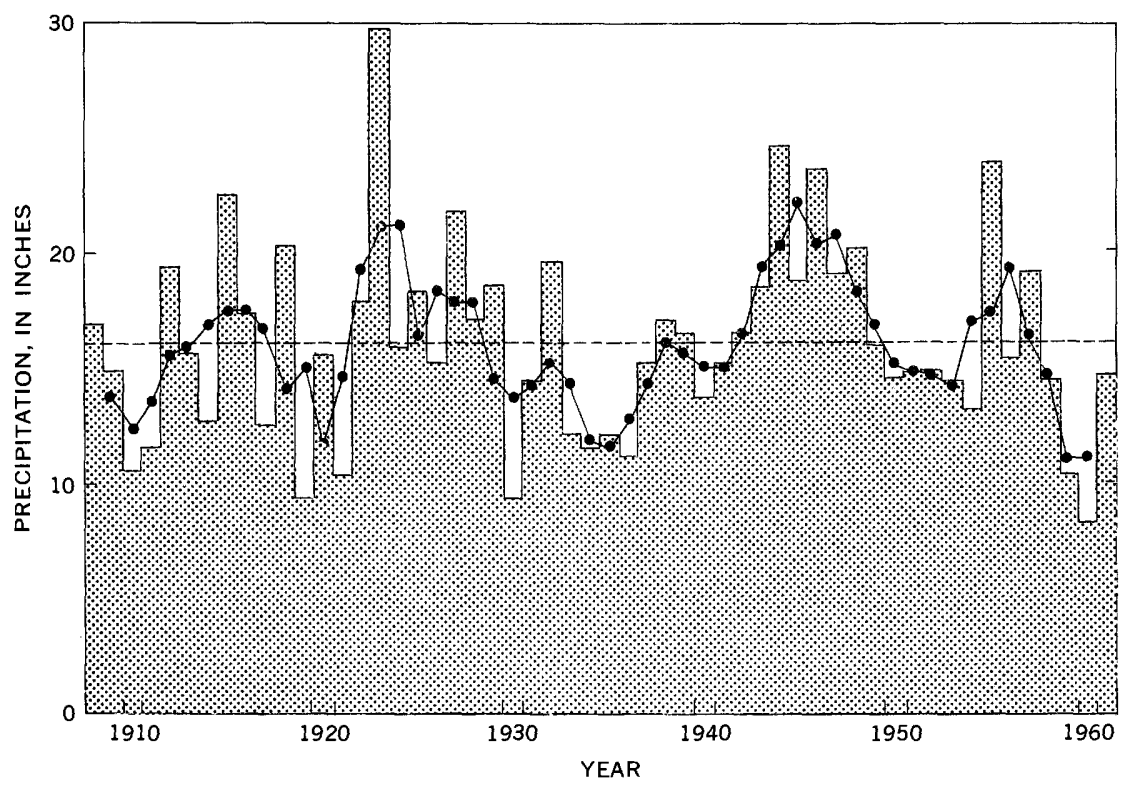

Figure 4.-Precipitation at Sheridan, Wyo.: annual (bar graph), normal (dashed line), and 3-year moving mean (points).

characteristics of the water in them is given in the section on geology and water resources. Logs of test holes, seismic shotholes, and selected wells, which are given in tables 6 and 7 at the end of the report, describe the materials penetrated by wells.

\section{GROUND WATER}

\section{PRINCIPLES OF OCCURRENCE}

Ground water is the water in the zone of saturation. In this zone the water is under hydrostatic pressure, and all the interstices are filled. The principal interstices in which ground water occurs are, in order of their significance, openings between adjacent particles composing sedimentary rocks, joints and other fracture openings, and solution cavities. Rocks that will yield sufficient quantities of water to be regarded as a source of supply are called aquifers. Aquifers are recharged chiefly by precipitation and influent streams, but infiltration of irrigation water is also a major source of recharge in some areas. Discharge from aquifers is through springs, seeps, effluent streams, and wells. Where ground water is near the surface, water may be lost directly to the atmosphere by evaporation and by transpiration from plants whose roots extend into the zone of saturation or into the overlying capillary fringe. 

GROUND-WATER RESOURCES, SHERIDAN COUNTY, WYO.

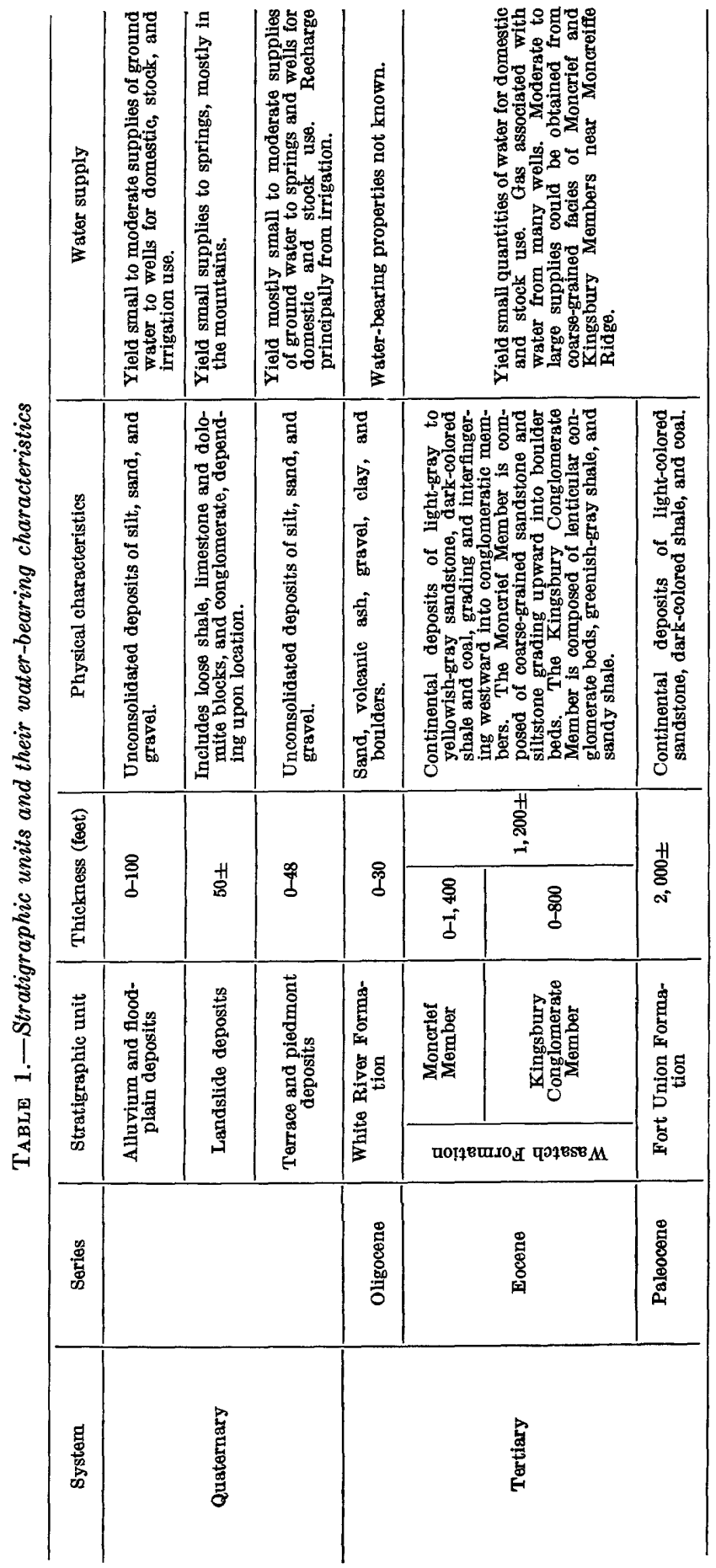




\begin{tabular}{|c|c|c|c|c|c|c|c|c|}
\hline 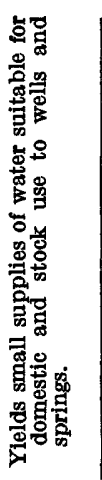 & 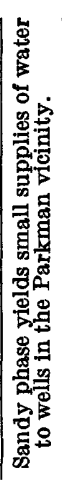 & 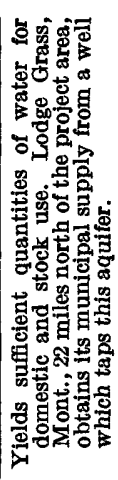 & 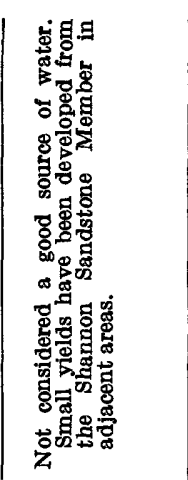 & 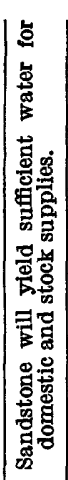 & 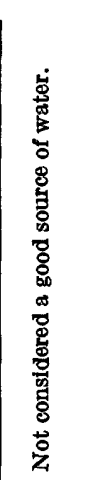 & 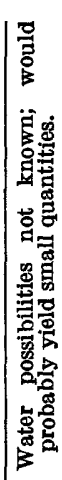 & 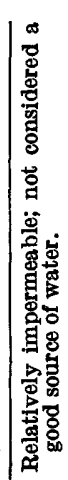 & 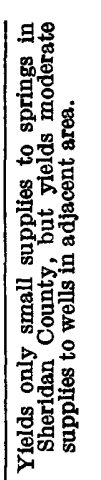 \\
\hline 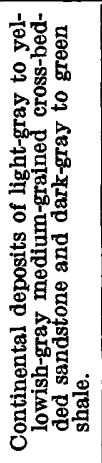 & 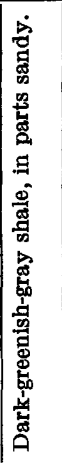 & 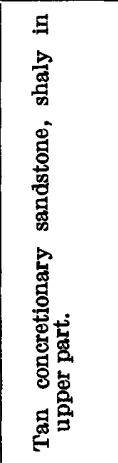 & 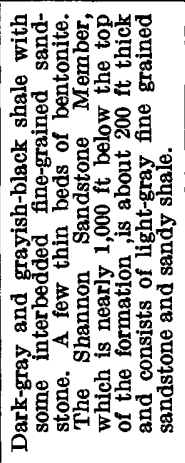 & 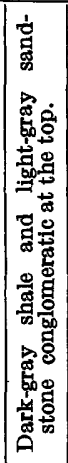 & 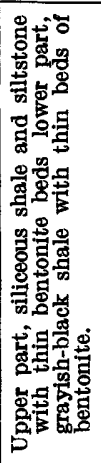 & 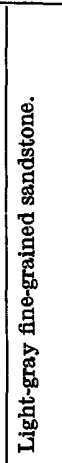 & 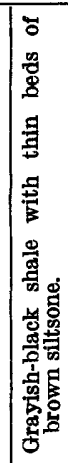 & 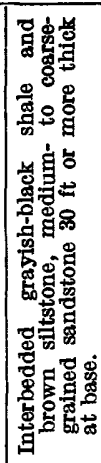 \\
\hline$\underset{-}{+H}$ & 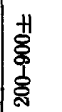 & 品 & 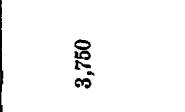 & 蒈 & 苦 & H & 苦 & 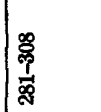 \\
\hline 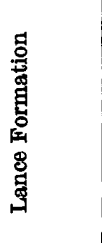 & 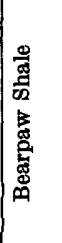 & 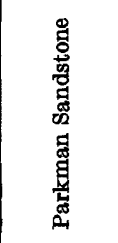 & 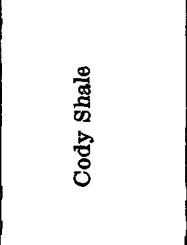 & 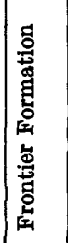 & 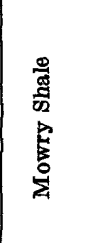 & 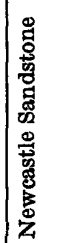 & 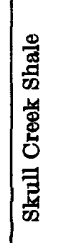 & 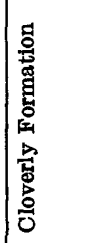 \\
\hline \multicolumn{5}{|c|}{ 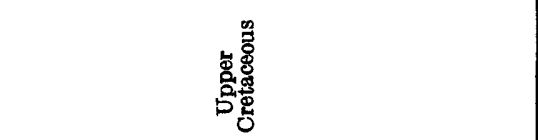 } & \multicolumn{4}{|c|}{ 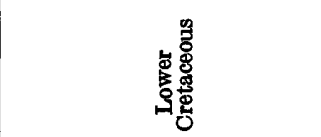 } \\
\hline
\end{tabular}

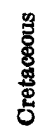



GROUND-WATER RESOURCES, SHERIDAN COUNTY, WYO.

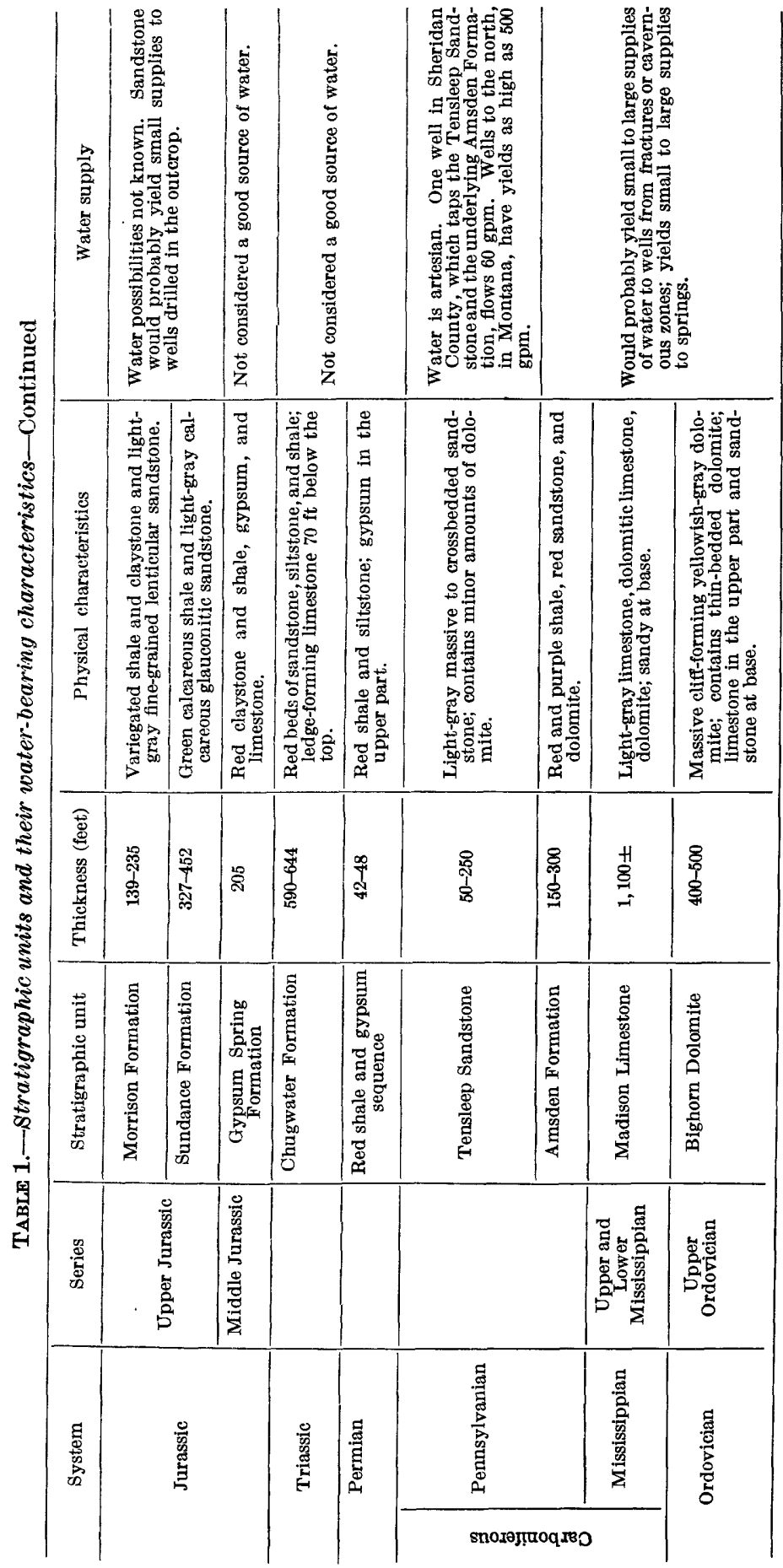




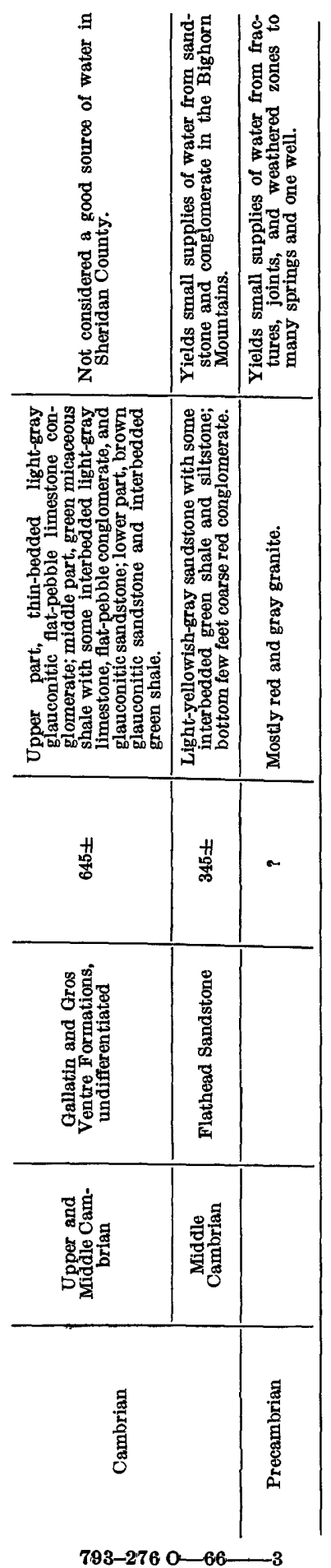


Ground water is under water-table conditions if the water level in an aquifer coincides with the top of the zone of saturation. It is under artesian conditions if the water is confined between relatively impermeable layers and the piezometric surface is above the top of the aquifer. In Sheridan County, water-table conditions exist in the unconsolidated aquifers of Quaternary age, in the shallower aquifers in the Tertiary formations, and in the pre-Tertiary aquifers within and close to the outcrop of the aquifers. Artesian conditions are generally present in the pre-Tertiary and in the deeper Tertiary aquifers. Gas is responsible for some of the lift in many wells in the Tertiary formations, where it is discharged with the water. Meinzer (1923, p. 40) stated: "An area in which the water rises to the surface because of the presence of gas cannot properly be called an area of artesian flow but may be called an area of gas-lift flow or may be designated by means of a brief description of the conditions."

\section{WATER-LEVEL FLUCTUATIONS}

The water level or piezometric surface in an aquifer is not stationary but fluctuates in response to external influences. If recharge is greater than discharge, the level rises; if discharge is greater, the level declines. Water levels in aquifers near the recharge area respond more quickly to changes in recharge and discharge than do those in aquifers farther away. Wells 58-87-35ca1 and 58-85-24da (fig. 5), which tap alluvium along intermittent streams, show a water-level decline because of below-normal precipitation during the time of the investigation. Well 57-85-19ab is beside a perennial stream, the Tongue River, and the water level fluctuates in response to the changes in stream stage. The gage height of flow in the Tongue River upstream from Dayton is shown in the hydrograph (fig. 5). Wells 53-83-7ad and 57-84-36ab (fig. 6), in consolidated rock, show declines in water levels similar to the declines in the two wells in the alluvium, but the rate of decline is more uniform. Discharge from the alluvial aquifers is principally by evaporation and transpiration, which become greatest during the growing season and negligible during the winter (fig. 5). Ground water is discharged from consolidated aquifers by springs, seepage to alluvium, and wells, and at a more uniform rate than that discharged from the alluvium. Movement of water out of the county as underflow undoubtedly occurs. The small rise of the water levels during the spring of 1961 in wells 53-83-7ad (fig. 6) and 58-85-24da (fig. 5 ) was a seasonal response to spring rains. Infiltration of water from a stock pond near well 57-84-36ab caused the upward trend in the last part of the hydrograph for that well (fig. 6). The pond was dry when previous measurements were made. 


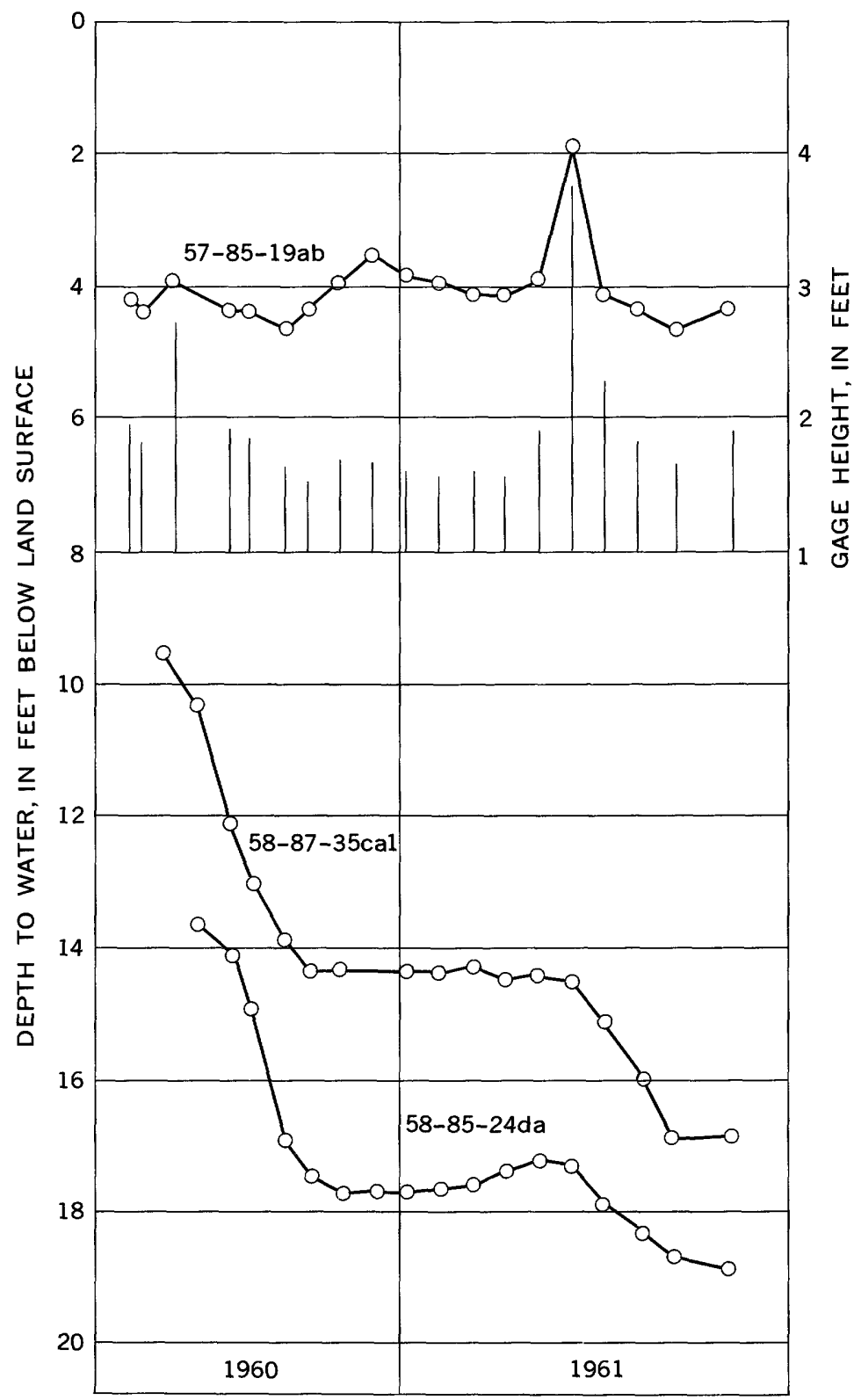

Fraure 5.-Hydrographs of three wells that penetrate the alluvium, and gage height of the Tongue River upstream from Dayton, Wyo. 


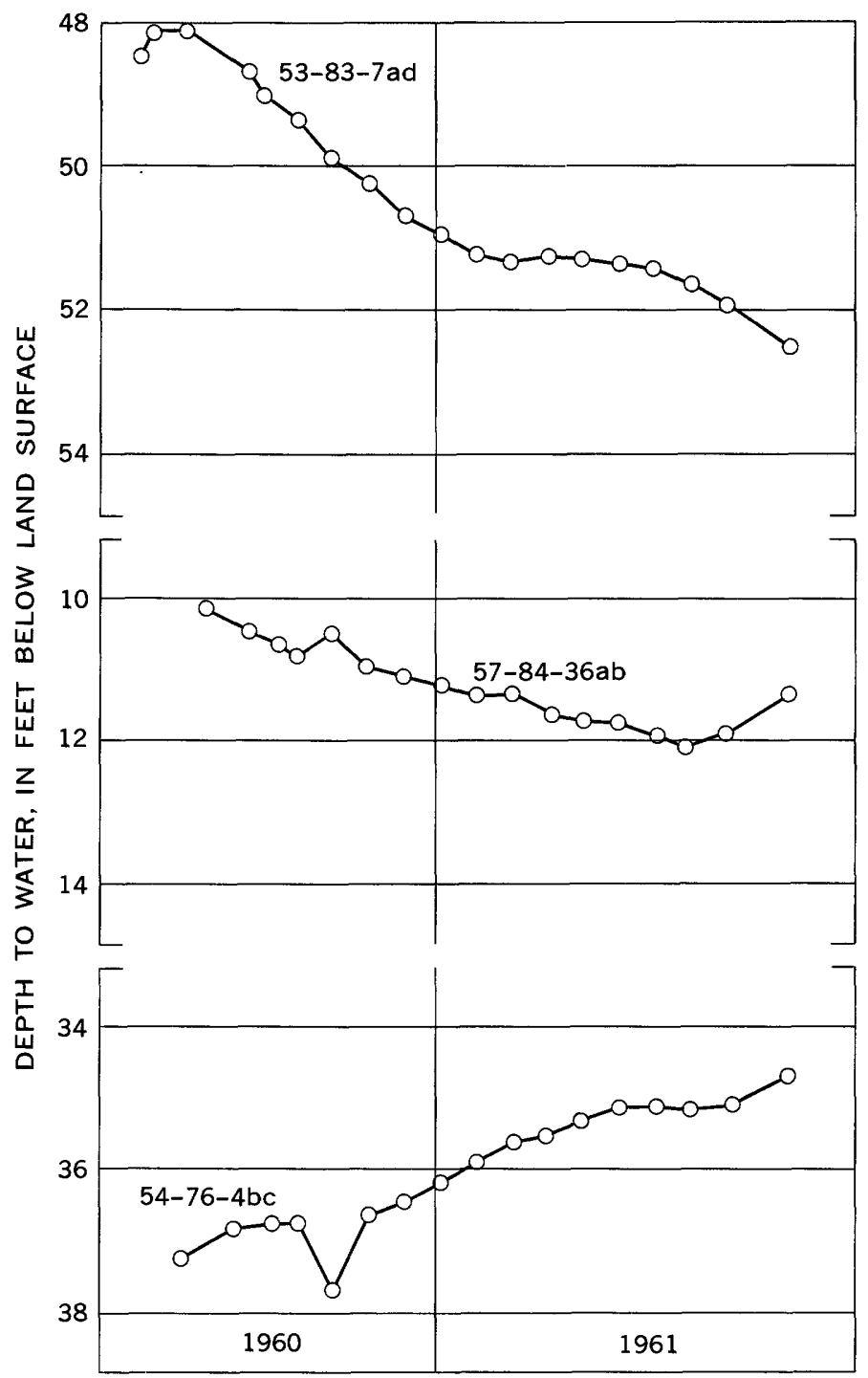

FraUne 6.-Hydrographs of three wells that penetrate formations of Tertiary age.

Well 54-76-4bc (fig. 6), which is in the central part of the Powder River Basin, is remote from the recharge area. The aquifer is deep enough that it is not immediately influenced by changes in recharge. The upward trend of the water level in the well during the time of the investigation probably correlates, with a time lag, to an earlier period when precipitation was greater. 
Effect of recharge from irrigation on water levels may occur quickly, or there may be a lag of several months. The levels in well 55-84-26cd in the alluvium and well 55-84-35ba in the Wasatch Formation rose almost immediately in response to irrigation which began about May 1, 1961 (fig. 7). The rise in level in well 55-85-34db, in the Fort Union Formation, lags some 2 months behind the start of the irrigation season.

When a well is pumped, or allowed to flow, the water level or piezometric surface near the well is lowered. The configuration of the water table or piezometric surface in the vicinity of a discharging well is that of an inverted cone with the apex at the well. The size of the cone depends upon the rate of discharge, the length of time the well has been discharging, and the hydraulic properties of the aquifer. When discharge ceases, the flow into the depression is rapid at first and then become more gradual, until the gradient toward the well no longer exists.

The water level near a discharging well (fig. 8) fluctuates in response to changes in the rate of pumping. The level in well 54-79$21 \mathrm{ab}$ is affected by the pumping of wells $54-79-21 \mathrm{bdd}$ and $54-79-21 \mathrm{bdb}$, which are public-supply wells for the town of Clearmont. The fluctuations of level in the observation well correlate with changes in the rate of pumping, as shown by the following data. During the period December 1960-February 1961, well 54-79-21bdd was pumped at about $8 \mathrm{gpm}$ (gallons per minute) for an average of 7.7 hours per day, and the water level in the observation well rose steadily. During March, April, and May, pumping time was increased to an average of 8.8,11.2, and 13.4 hours per day, respectively, and the upward trend of the water level was reversed. Beginning the first of June, well 54-79$21 \mathrm{bdd}$ was pumped almost continuously and, in addition, well 54-79$21 \mathrm{bdb}$ was pumped for about 3 hours a day; the result was a rapid decline of the water level.

\section{HYDRAULIC PROPERTIES OF AQUIFERS}

The rate at which an aquifer will yield water to wells depends upon the hydraulic properties, principally the coefficients of permeability and storage.

The coefficient of permeability is defined as the rate of flow of water, in gallons per day (gpd), through a cross-sectional area of 1 square foot under a unit hydraulic gradient. The standard coefficient is defined for water at a temperature of $60^{\circ} \mathrm{F}$; whereas, the field coefficient requires no correction for temperature, and the units are in the terms of the prevailing water temperature. The coefficient of transmissibility is the product of the coefficient of permeability and the 
18 GROUND-WATER RESOURCES, SHERIDAN COUNTI, WYO.

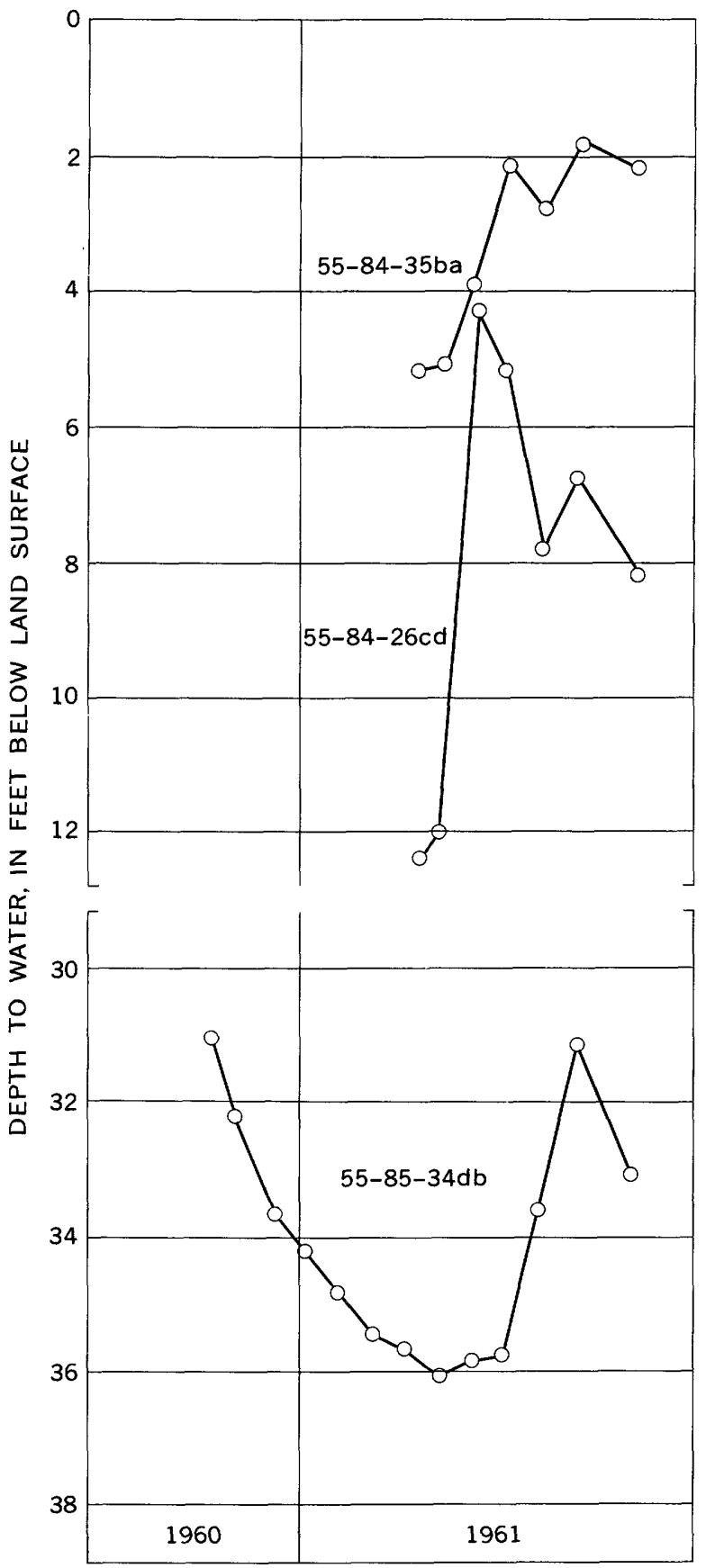

Figure 7.-Hydrographs of three wells penetrating aquifers affected by irrigation. 

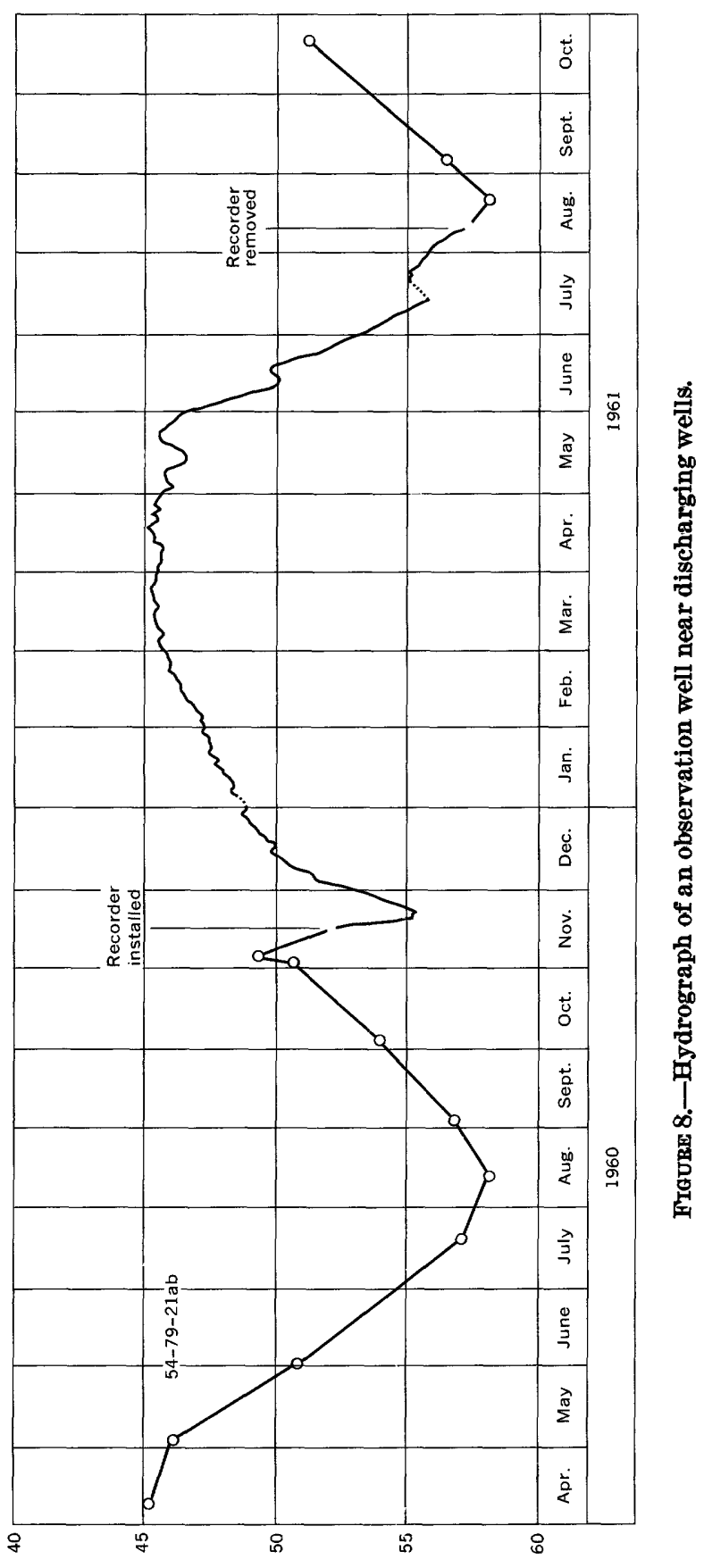
thickness of the aquifer and is expressed in gallons per day per foot (gpd per ft).

The coefficient of storage of an aquifer is the volume of water which the aquifer releases from or takes into storage per unit surface area of the aquifer per unit change in the component head normal to that surface. This quantity is approximately equal to the specific yield, which expresses the quantity of water that a given saturated volume of aquifer will yield by gravity drainage under water-table conditions. The ratio of the volume of water to the total volume of water drained is the specific yield. The specific retention is the quantity of water retained against the pull of gravity. Specific retention plus specific yield is equal to porosity.

\section{FIELD TESTS OF AQUIFERS}

Aquifer tests were made at six wells - two each of which penetrate the alluvium, the Fort Union Formation, and the Wasatch Formation. The wells were pumped at a constant rate during the tests, and periodic measurements of the water levels were made while the well was being pumped or during the recovery of the water level after the pumping had stopped. The data were analyzed by the "nonequilibrium" methods described by Theis (1935) and Cooper and Jacob (1946).

The results of the pumping tests are given in table 2. Aquifer characteristics computed from the tests of wells drilled into the Fort Union and the Wasatch Formations do not apply to the entire stratigraphic interval, but only to the aquifer in which the well is finished. The test results illustrate the aquifer characteristics that may be expected for wells penetrating either of these two formations.

Aquifers having low coefficients of transmissability and storage, such as those at well 55-84-27bc, are capable of supplying sufficient water for domestic and stock supplies. Continuous pumping for as long as 2 hours, however, sometimes lowers the water level to the lower

TABLE 2.-Results of pumping tests

\begin{tabular}{|c|c|c|c|c|c|}
\hline Well & $\begin{array}{c}\text { Coefficient of } \\
\text { transmis- } \\
\text { sibility (gpd } \\
\text { per ft) }\end{array}$ & $\begin{array}{c}\text { Coefficient of } \\
\text { storage }\end{array}$ & $\begin{array}{l}\text { A verage field } \\
\text { coefficient of } \\
\text { permeability } \\
\text { (gpd per sq ft) }\end{array}$ & Aquifer & Remarks \\
\hline 54-84-5da_..- & 95 & $3.5 \times 10^{-4}$ & 7.9 & Sandstone in the & 24-hr test. \\
\hline $\begin{array}{l}54-81-14 \mathrm{bc} \\
57-83-14 \mathrm{ba}-.-\end{array}$ & $\begin{array}{r}520 \\
2,200\end{array}$ & $2.4 \times 10^{-2}$ & 6.5 & $\begin{array}{l}\text { Coal in the Wasatch. } \\
\text { Sandstone(?) in the }\end{array}$ & $\begin{array}{l}\text { Do. } \\
\text { 3. 5-hr recovery test. }\end{array}$ \\
\hline $55-84-27 \mathrm{bc}$ & 10 & $9 \times 10^{-5}$ & 2.5 & Sandstone in the & $1.3 \mathrm{hr}$ recovery test. \\
\hline $\begin{array}{l}56-82-34 d c- \\
57-85-19 a b-.\end{array}$ & $\begin{array}{r}9,700 \\
20,300\end{array}$ & & $\begin{array}{r}380 \\
1,100\end{array}$ & Alluvium & $\begin{array}{l}\text { 8-hr recovery test. } \\
\text { Average from 10-day } \\
31 / 2 \text {-hr tests. }\end{array}$ \\
\hline
\end{tabular}


end of the suction pipe, even though the pump has been set as low as possible.

Because of the lenticularity of the aquifers, impermeable boundaries probably exist in most areas where wells are drilled into the Fort Union and Wasatch Formations. An impermeable boundary near a pumped well may cause an increased drawdown in the well. Such boundaries ordinarily would not be an appreciable factor affecting the water levels in domestic and stock wells, because of the normally short duration of pumping and the small discharge from the wells.

The alluvium in some of the larger valleys is probably capable of yielding moderate quantities $(50-300 \mathrm{gpm})$ of water to wells; still, before construction of a large-diameter well, test holes should be drilled and the quality of the water with respect to its intended use should be determined.

\section{SPECIFIC CAPACITY OF WELIS}

The specific capacity of a well is the number of gallons per minute that a well will yield for each foot of drawdown. Specific capacity varies with time and with different rates of pumping, except where the different rates cause only small drawdowns in the pumped well. Wells in aquifers having similar characteristics may have different specific capacities because of differences in construction and development of the wells.

A summary of the reported specific capacity of wells tapping the Fort Union Formation and the fine-grained facies of the Wasatch Formation is given in table 3. The duration of pumping was not ordinarily reported, but where reported, it generally ranged from 3 to 8 hours. The data do not show any significant difference between the specific capacity of wells in the Fort Union Formation and of those in the Wasatch Formation. The average specific capacity of 15 wells that tap the coarse-grained facies of the Wasatch is $1.0 \mathrm{gpm}$ per foot of drawdown.

TABLE 3.-Reported specific capacity of wells in the Fort Union and Wasatch Formations

\begin{tabular}{|c|c|c|c|c|c|c|}
\hline \multirow{2}{*}{$\begin{array}{l}\text { Specific capacity (gpm per foot } \\
\text { of drawdown) }\end{array}$} & \multicolumn{2}{|c|}{$\begin{array}{l}\text { Fort Union } \\
\text { Formation }\end{array}$} & \multicolumn{2}{|c|}{ Wasatch Formation } & \multicolumn{2}{|c|}{$\begin{array}{l}\text { Fort Union and } \\
\text { Wasatch Formations }\end{array}$} \\
\hline & $\begin{array}{l}\text { Number } \\
\text { of wells }\end{array}$ & $\begin{array}{l}\text { Percent } \\
\text { of wells }\end{array}$ & $\begin{array}{l}\text { Number } \\
\text { of wells }\end{array}$ & $\begin{array}{l}\text { Percent } \\
\text { of wells }\end{array}$ & $\begin{array}{l}\text { Number } \\
\text { of wells }\end{array}$ & $\begin{array}{l}\text { Percent } \\
\text { of wells }\end{array}$ \\
\hline $\begin{array}{l}\text { Less than } 0.1 \\
\text { Less than } 1.0 \text {, but more than } 0.1 \\
\text { More than } 1.0\end{array}$ & $\begin{array}{l}\mathbf{2 2} \\
\mathbf{5 2} \\
\mathbf{1 1}\end{array}$ & $\begin{array}{l}26 \\
61 \\
13\end{array}$ & $\begin{array}{r}14 \\
21 \\
3\end{array}$ & $\begin{array}{r}37 \\
\mathbf{5 5} \\
\mathbf{8}\end{array}$ & $\begin{array}{l}36 \\
73 \\
14\end{array}$ & $\begin{array}{l}29 \\
59 \\
12\end{array}$ \\
\hline Average specific capacity. . . . & \multicolumn{2}{|c|}{0.42} & \multicolumn{2}{|c|}{0.33} & \multicolumn{2}{|c|}{0.39} \\
\hline
\end{tabular}

$793-2760-66-4$ 
Wells in the alluvium have the largest specific capacities reported. The specific capacity of wells drilled in the alluvium ranged from 0.3 to $7.0 \mathrm{gpm}$ per foot of drawdown; for 20 of these wells, it averaged 3 gpm per foot of drawdown.

\section{INTERFERENCE BETWEEN WELLS}

When discharging wells are too closely spaced, the cones of depression sometimes overlap, or interfere, and lower pumping levels or decreased artesian flows result. Most of the interference reported in the area has been between flowing wells in eastern and central Sheridan County. Although interference actually occurs between some wells, it is only apparent in many others. The apparent interference may be the result of impermeable boundaries or a decrease in the gas-water ratio where gas is associated with the water, or both. There have been few reports of interference in the areas of greatest ground-water development-south of Sheridan and at Story. In these areas the wells are not heavily pumped, recharge conditions are excellent, and adjacent wells are often completed in different aquifers.

\section{UTILIZATION OF GROUND WATER}

The principal use of ground water in Sheridan County is for domestic and stock supplies. Most domestic water supplies in the rural areas are from wells, although a few springs have been developed. The wells generally are of small diameter and are drilled only deep enough to obtain an adequate supply of water of acceptable quality.

In some areas, drilled wells are the only source of water for stock; but in other areas wells supplement surface supplies. Stock wells are similar in construction to domestic wells; but, in localities where flowing wells can be developed, a stock well is commonly drilled to a depth of more than 1,000 feet, rather than being completed as a nonflowing well at a lesser depth. Numerous springs in the mountains also supply much water for stock.

Except for the town of Clearmont, which uses ground water, all the municipal water supplies in Sheridan County are from surface water. The average use of ground water by Clearmont in the winter is about $4,000 \mathrm{gpd}$. No figures are available for either summer or annual use. Residents in the communities of Big Horn, Arvada, and Story use water from private wells, and some wells are shared by two or more families. The towns of Acme and Monarch, which are not municipalities but are privately owned, obtain water from large-diameter dug wells in the alluvium along the Tongue River. 


\section{REPORTING OF CHEMICAL-QUALITY DATA}

The concentrations of dissolved chemical constituents are generally expressed in parts per million ( $\mathrm{ppm}$ ) in data on chemical quality of water. A part per million is one unit weight of a constituent in 1 million unit weights of water. Frequently, working with equivalents per million (epm) is more convenient in special problems in water chemistry and the effects of irrigation waters on soils. An equivalent per million is one unit chemical combining weight of a constituent in 1 million unit weights of water. Equivalents per million are calculated by dividing the concentration of the constituent, in parts per million, by its chemical combining weight.

The specific conductance of water is a measure of the ability of water to conduct an electric current and is expressed in micromhos per centimeter at $25^{\circ} \mathrm{C}$. Because specific conductance is related to the amount of dissolved material, it can be used for approximating the dissolvedsolids content of water. The $\mathrm{pH}$ indicates the degree of acidity or alkalinity. A pH progressively higher than 7 denotes increasing alkalinity, and a pH progressively lower than 7 denotes increasing acidity.

Water is commonly referred to as of a certain chemical type. The following examples illustrate how these designations are determined:

1. "Calcium bicarbonate" designates a water in which the calcium amounts to 50 percent or more of the cations and in which the bicarbonate amounts to 50 percent or more of the anions, based on equivalents per million.

2. "Sodium-calcium bicarbonate" designates a water in which the sodium and calcium are first and second, respectively, in order of abundance among the cations, but neither amounts to more than 50 percent of all the cations.

3. "Sodium sulfate bicarbonate" designates a water in which the sulfate and bicarbonate are first and second in order of abundance among the anions, but neither amounts to more than 50 percent of all the anions.

\section{WATER-QUALITY CRITERIA}

In the evaluation of the suitability of water for beneficial uses, certain water-quality criteria that are generally accepted as valid should be considered. A discussion of these criteria follows.

\section{DOMESTIC USE}

Chemical-quality standards for water to be used for drinking and culinary purposes on interstate-commerce carriers were established by 
the U.S. Public Health Service (1962). Although these standards established recommended allowable-concentration limits for water to be used on common carriers, many municipal and domestic water supplies exceed these allowable-concentration limits in some respects. The absence of suitable supplies and the high cost of treatment prevents strict adherence to these suggested standards. Some of the limits on chemical constituents in drinking water are as follows:

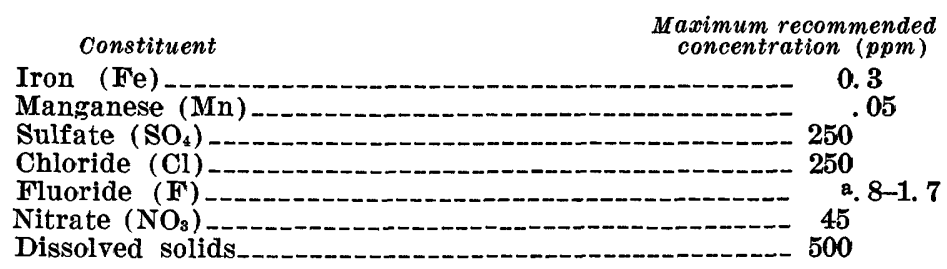

a Recommended limits for fluoride content are based on the annual average of maximum daily air temperatures. For example, when the average is $50.0^{\circ} \mathrm{F}$ to $53.7^{\circ} \mathrm{F}$ the recommended upper limit is $1.7 \mathrm{ppm}$; when the average is between $79.3^{\circ} \mathrm{F}$ to $90.5^{\circ} \mathrm{F}$, the upper limit is $0.8 \mathrm{ppm}$

Hardness, a property of water familiar to many people, is caused principally by the presence of calcium and magnesium. Arbitrarily, water has been classified in the following manner with regard to hardness : $60 \mathrm{ppm}$ or less, soft; $61-120 \mathrm{ppm}$, moderately hard; 121-180 ppm, hard; and $181 \mathrm{ppm}$ or more, very hard.

\section{AGRICULTURAL USE}

Although investigations relating the chemical quality of water to its suitability for agricultural use are not numerous, guidelines usually considered reliable have been proposed (Beath and others, 1953; Eaton, 1950; U.S. Salinity Laboratory Staff, 1954). The following statements have been drawn largely from these reports. Many supplies of water that do not fully meet these requirements have been used for many years for agriculture in localities where other water supplies are not available.

Although many chemical constituents or properties of water affect its suitability for irrigation, the two main criteria for determining a suitable supply are the dissolved-solids content and the sodium concentration relative to the calcium and magnesium concentrations. Also, the concentrations of bicarbonate, boron, and selenium are significant under certain conditions.

The significance of water having a high dissolved-solids content (salinity) is that the application of such water to the land tends to upset the salt balance in the soil. The use of saline water in the absence of a favorable salt balance results in the retardation of plant growth, because such water increases the osmotic pressure in the soil 
solution. As a rule, the higher the salinity of a water, the less suitable the water is for use. Because the salinity of water is closely related to the specific conductance of water, the specific conductance may also be used as a measure of the salinity hazard of water.

When the relative concentration of sodium in irrigation water is greater than that of calcium and magnesium, the sodium tends to replace the calcium and magnesium adsorbed on soil colloids. Soil colloids then tend to disperse and, thus to restrict the movement of air and water through the soil; a soil having poor tilth and low permeability results. As a measure of the suitability of water for irrigation use, the sodium-adsorption-ratio (SAR) is frequently used. It is an indicator of the degree of hazard entailed in the use of water that has a high sodium content.

Investigations of the relation of water quality to the health of stock have not been numerous, and, therefore, rigid criteria for evaluating the usefulness of a stock-water supply are difficult to establish. Stock are capable of good health even when they drink water considered to be unfit for human consumption. Nevertheless, a high dissolved-solids content can cause poor growth, sickness, and even death. Beath and others (1953) suggested the following classification as a guide for evaluating stock water.

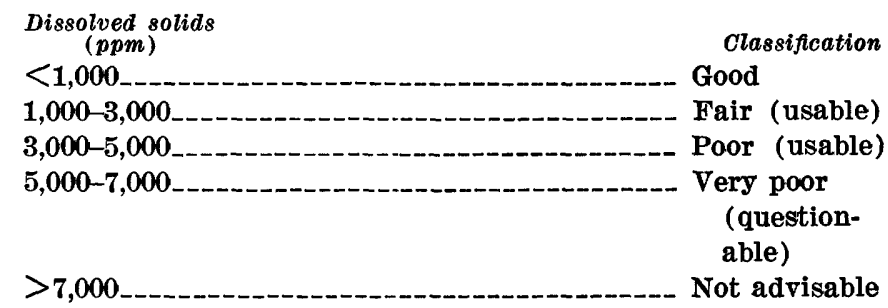

Harmful effects to stock have been attributed to the selenium, sulfate, and fluoride contents in water supplies. A high iron content may make water unpalatable to stock.

\section{INDUSTRIAI USE}

The water-quality requirements of industry depend largely upon the specific use to be made of water. Reports by Moore (1940) and by the California State Water Pollution Control Board (1952) contain information on industrial water-quality standards and may be consulted for criteria applicable to a specific use. Generally, water that has a low dissolved-solids content and low hardness and does not vary greatly in quality or temperature meets the requirements of most industries. 


\section{GEOLOGY AND WATER RESOURCES}

\section{FORMATIONS OF PRE-TERTIARY AGE}

Formations that range from Precambrian to Late Cretaceous in age are exposed in the Bighorn Mountains and in a narrow band along the mountain front, but they are deeply buried throughout most of the project area. The age, thickness, physical characteristics, and water-bearing properties of these rocks and others are summarized in table 1. Only rocks of pre-Tertiary age that are potential sources of large supplies of ground water are described in detail. Other aquifers of pre-Tertiary age will generally yield only small supplies of ground water to wells.

Bighorn Dolomite.-The Bighorn Dolomite of Late Ordovician age is about 500 feet thick near the Montana State line, but it thins southward to less than 400 feet at the Sheridan-Johnson County line (Richards and Nieschmidt, 1961, sheet 1). The formation generally is divided into three units. The basal sandstone, which is about 30 feet thick in Sheridan County, consists of crossbedded friable white sandstone. The middle (cliff-forming) unit is about 280 feet thick. It consists of massive dolomite that weathers to a characteristic rough, pitted surface. The upper unit is about 150 feet thick and consists of thin-bedded dolomite and dolomitic limestone, which generally form slopes above the middle-unit.

Madison Limestone.-The Madison Limestone of Early and Late Mississippian age is exposed as a series of ledges formed by resistant beds. Caverns (fig. 9) and castellated forms are typical, especially in the upper part of the formation. The formation is composed of limestone, dolomitic limestone, and dolomite. It is about 1,100 feet thick in Sheridan County (Darton, 1904, p. 394) but thins to the south in Johnson County.

Amsden Formation.- The Amsden Formation of Pennsylvanian age consists of cherty dolomite, red sandstone, and red and purple shale. The formation was deposited upon the eroded surface of rocks of Mississippian age, and it varies considerably in thickness within short distances. It is about 150 feet thick near the Montana State line and thickens southward to about 250 feet at the Sheridan-Johnson County line. The formation weathers to form the red slopes between the resistant Tensleep and Madison Formations.

Tensleep Sandstone.-The Tensleep Sandstone of Pennsylvanian age forms steep dip slopes along most of the mountain flank. The formation is dominantly a resistant crossbedded sandstone with minor amounts of dolomite. It probably is conformable with the under- 


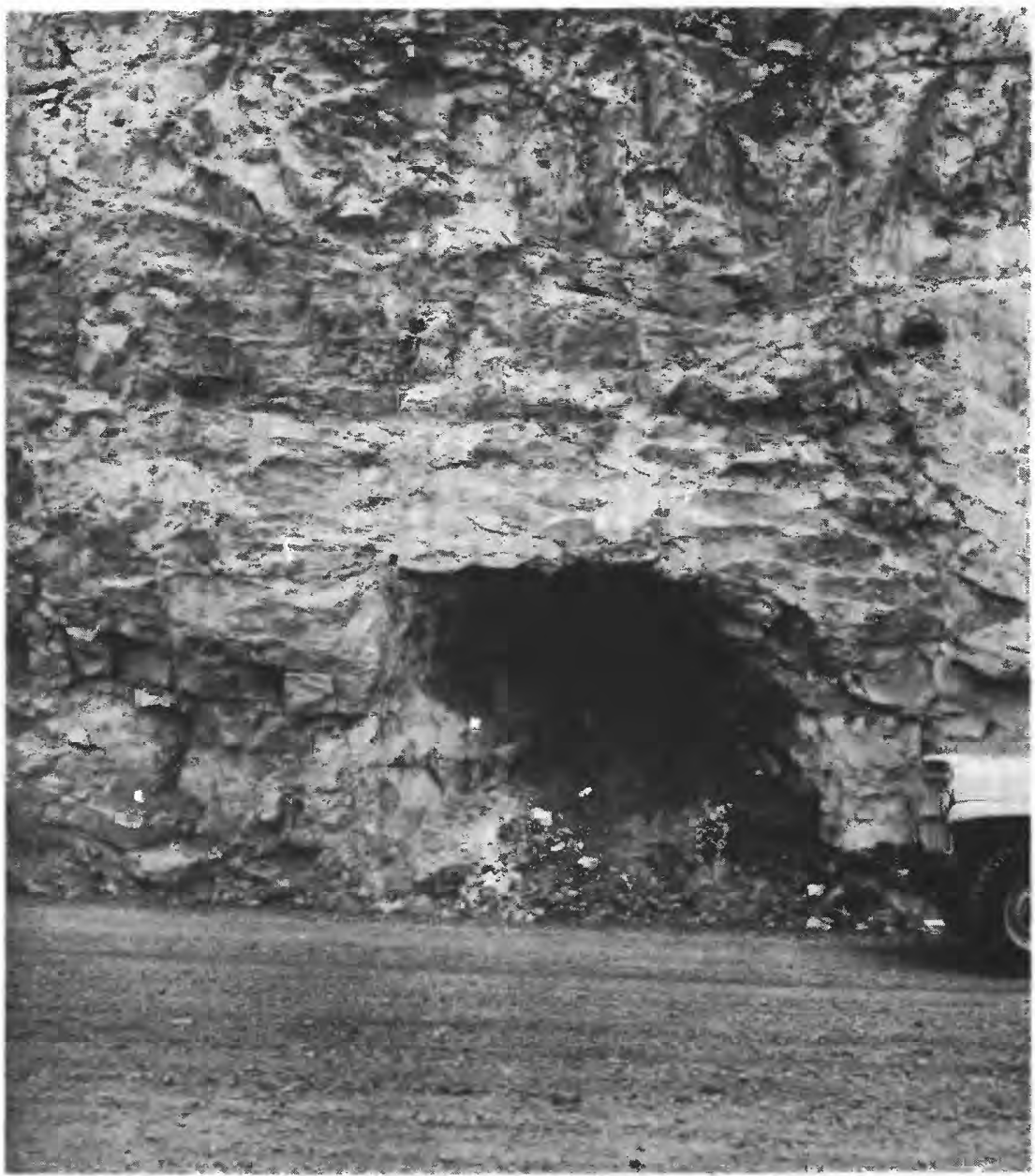

Frgure 9.-Cavern in the Madison Limestone along U.S. Highway 14 in T. 56 N., R. 87 W.

lying Amsden Formation. The formation thickens from about 50 feet at the State line to about 250 feet at the Sheridan-Johnson County line.

\section{WATER-BEARING PROPERTIES}

The aquifers of pre-Tertiary age consist principally of tightly cemented sandstone and carbonate rocks that generally do not have a large primary permeability - that is, permeability due to interstices which were formed contemporaneously with the rock. The Tensleep Sandstone, however, has sufficient primary permeability to yield mod- 
erate and possibly large supplies of water to wells. Large yields obtained from the Bighorn Dolomite, Madison Limestone, and Amsden Formation would be principally from zones of secondary permeability - that is, permeability due to fracturing and solution affecting the rocks after deposition. Some wells penetrating these formations to the west of Sheridan County have artesian flows of more than 1,000 gpm. The most productive wells generally are near structural features where fracturing and solution have increased the permeability. Wells penetrating other aquifers of pre-Tertiary age will probably have small yields.

\section{RECHARGE AND DISCHARGE}

Recharge to formations of pre-Tertiary age is from precipitation and streamflow. Recharge conditions are favorable throughout the outcrop. Farther east, however, the formations are deeply buried, and recharge is negligible.

Discharge from formations of pre-Tertiary age is through wells, seeps, and springs. All the known discharge points are in the outcrop. Much of the potential recharge of these formations is probably rejected. A description of some of the different types of springs follows to illustrate the recharge-discharge relations, as well as the ground water occurrence.

Contact springs.-Contact springs in Sheridan County may be present where an aquifer is underlain by less permeable beds. Ground water percolates down to the less permeable bed and then moves laterally to the point of discharge. Leaky Mountain Spring (57$90-?)$, which is an unusually large spring for the region, yields about 1,000 gpm and issues from the Bighorn Dolomite at its contact with the underlying Gallatin Formation of Late Cambrian age.

Landstide springs.-Springs issuing from landslide deposits, such as spring 55-90-16b, are common in the Gallatin and Gros Ventre Formations. The slides are caused, in part, by the contact springs at the base of the overlying Bighorn Dolomite. The relation is apparent at Duncom Mountain, which is on the drainage divide between the Powder River Basin and the Bighorn Basin. Erosion has stripped away the sedimentary rocks down to and including much of the Bighorn Dolomite, and the topography is marked by large solution cavities formed in fractures and in other zones of weakness in the formation. The shale of Cambrian age, which forms the grass-covered slopes below the Bighorn Dolomite, has a hummocky topography that is typical of landslide deposits. 
Water percolates downward through the solution cavities in the Bighorn Dolomite to the underlying Cambrian shale and then moves laterally to the point of discharge. The shale is then more susceptible to gravity movement because of the additional weight of the absorbed water and the lubrication of the shale by the water. After the initial movement of the shale and overlying strata, the hummocky topography is capable of retaining snow and runoff, which furnishes additional water to the springs.

Springs from joints, fractures, and tubular openings.-Springs issue from rock openings ranging in size from small fractures or joints to large faults. The spring at Preacher Rock (54-86-32c) flows about $5 \mathrm{gpm}$ from joints in the Precambrian granite, whereas spring 53$84-13 \mathrm{bd}$, which is hydraulically connected with South Piney Creek, flows from sedimentary rocks through openings associated with faults. The flow of the spring ranges from 400 to $1,000 \mathrm{gpm}$, in direct response to streamflow.

The entire course of Cave Creek is through tubular openings, some of which can be seen in the Tongue River Cave. The creek discharges into the Tongue River below the level of the river. The point of discharge is not visible. A dye study was made to determine whether the source of the water in Cave Creek was the Little Tongue River. Fluorescein dye was mixed with the water of the Little Tongue River in sec 31, T. 56 N., R. 87 W., and the dye was observed later in Cave Creek. The time required for the dye to reach the point of observation was between 37 and 45 hours. The straight-line distance between the two points is about 2.5 miles, and the difference in altitude is about 2,500 feet. The flow of Cave Creek was about $900 \mathrm{gpm}$ at the time of the dye study.

\section{QUALITY OF WATMER}

Chemical analyses of water from rocks of pre-Tertiary age are given in table 4. Samples of water were obtained from the Flathead Sandstone of Cambrian age, the Amsden Formation and Tensleep Sandstone of Pennsylvanian age, and the Frontier, Parkman, Bearpaw, and Lance Formations, all of Cretaceous age. The quality of water from these formations varies widely: the dissolved-solids content of water ranges from 124 to $1,320 \mathrm{ppm}$; hardness, from $18 \mathrm{ppm}$ (soft) to 407 ppm (very hard) ; and iron content, from 0.00 to $1.3 \mathrm{ppm}$. The quality of water in each formation probably also varies from place to place, as illustrated by analyses of water from the Lance Formation (table 4).

793-276 $0-66-5$ 
TABLE 4.-Chemical analyses of ground

[Results in parts per million except as

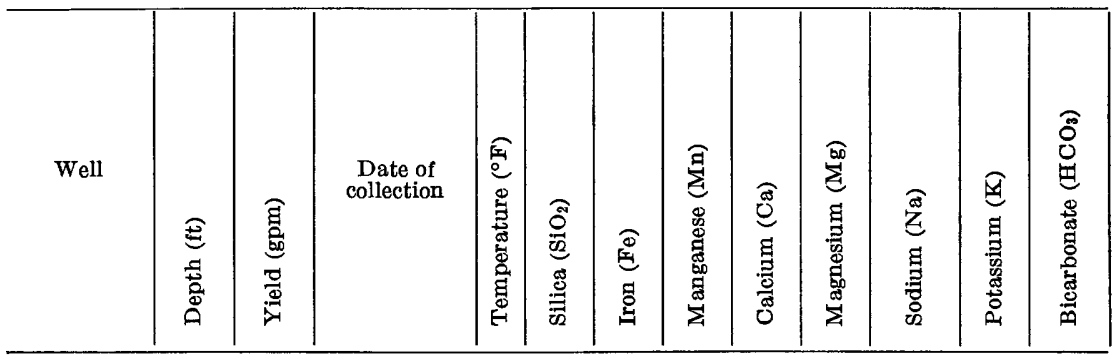

Flathead

\begin{tabular}{|r|r|r|r|r|r|r|r|r|r|r|r|r|}
\hline $55-89-1 \mathrm{da} . . .$. & 66 & $220 \mathrm{R}$ & Oct. 25, 1960 & 42 & 6.8 & 0.19 & 0.00 & 30 & 7.8 & 2.0 & 0.2 & 128 \\
\hline
\end{tabular}

Amsden Formation and

\begin{tabular}{|l|c|c|c|c|c|c|c|c|c|c|c|c|}
\hline $57-87-21 \mathrm{db} \ldots$ & 1,596 & 64 & Oct. 25, 1960 & 50 & 8.0 & 0.58 & 0.00 & 50 & 19 & 0.5 & 0.6 & 246 \\
\hline
\end{tabular}

Frontier

\begin{tabular}{l|r|r|r|r|r|r|r|r|r|r|r|r|}
\hline $56-86-7 \mathrm{dc}----$ & 148 & $2 \mathrm{R}$ & July 27, 1961 & --- & 10 & 0.02 & 0.05 & 47 & 14 & 74 & 1.0 & 277 \\
\hline
\end{tabular}

Parkman

\begin{tabular}{|l|r|r|r|r|r|r|r|r|r|r|r|r|}
\hline $57-86-30 a c$ & 115 & $4 \mathrm{R}$ & Oct. 25, 1960 & 49 & 13 & 1.3 & 0.00 & 97 & 40 & 29 & 2.0 & 330 \\
\hline
\end{tabular}

Bearpaw

\begin{tabular}{|l|r|r|r|r|r|r|r|r|r|r|r|r|}
\hline $58-87-35 \mathrm{ca2} . .-$ & 129 & $6 \mathrm{R}$ & Oct. 25, 1960 & 49 & 38 & 0.44 & 0.00 & 16 & 2.9 & 236 & 0.1 & 337 \\
\hline
\end{tabular}

Lance

\begin{tabular}{c|c|c|c|c|c|c|c|c|c|c|c|c|}
\hline $57-86-34 b b_{\ldots} .$. & 315 & .75 & Aug. 28, 1961 & 54 & 8.4 & 0.13 & 0.00 & 33 & 18 & 404 & 5.3 & 592 \\
$57-87-1 b d$ & 195 & $8 \mathbf{R}$ & $\ldots . .00$ & .00 & 5.6 & 1.0 & 150 & .8 & 191 \\
\hline
\end{tabular}

Fort Union

\begin{tabular}{|c|c|c|c|c|c|c|c|c|c|c|c|c|}
\hline $53-77$ & 424 & 1.3 & Oct. 26,1960 & 67 & 12 & 0.47 & 0.02 & 22 & 7.8 & 620 & 7.4 & 1,710 \\
\hline 54-76-5ac & 710 & 7 & Aug. 29,1961 & 64 & 12 & .72 & .00 & 19 & 3.5 & 524 & 6.0 & 1,430 \\
\hline $54-77-5$ & 1,185 & 1.64 & Aug. 30,1961 & 62 & 13 & .08 & .02 & 5.9 & 2.1 & 400 & 5.3 & 1,040 \\
\hline & 743 & $12 \mathrm{R}$ & Oct. 261960 & 59 & 10 & .91 & .00 & 18 & 3.4 & 537 & 4.3 & 1,450 \\
\hline $55-77-28$ & 380 & $6 \mathbf{R}$ & Mar. 7,1962 & 56 & 9.0 & .21 & .00 & 4.6 & .8 & 219 & 1.8 & 553 \\
\hline $28 d$ & 500 & .75 & Mar. 6,1962 & 55 & 9.6 & .20 & .00 & 12 & 2.6 & 374 & 4.5 & 1,000 \\
\hline $55-84-16$ & 370 & .75 & Aug. 30,1961 & 54 & 8.6 & 3. 2 & .00 & 62 & 30 & 134 & & 499 \\
\hline $27 \mathrm{c}$ & 560 & $1 \mathbf{R}$ & June 14,1962 & 57 & 8.7 & .19 & .00 & 28 & 8.3 & 141 & 6.5 & 454 \\
\hline $56-78-22$ & 165 & 1 & Aug. 30,1961 & 59 & 9.2 & .14 & .00 & 7.3 & 2.9 & 400 & 3.5 & 1,110 \\
\hline $56-8$ & 123 & $25 \mathrm{R}$ & July 27,1961 & 50 & 9. & .91 & .03 & 43 & 28 & & & 510 \\
\hline $57-76-20$ bd. & 265 & 1.47 & Oct. 26,1960 & 52 & 9.1 & .88 & .06 & 12 & 2.2 & 555 & 4.4 & 1,480 \\
\hline $57-83-3 a b$ & 120 & $3 \mathbf{R}$ & Mar. 8,1962 & 48 & 8. & .19 & .00 & 8.4 & 2.8 & 49 & 4.7 & 1,320 \\
\hline $57-84-19 b d$ & 126 & $15 \mathrm{R}$ & Mar. 6,1962 & 48 & 9. & .10 & .00 & 31 & 29 & 810 & 17 & 2,370 \\
\hline $57-$ & 180 & $\mathbf{5 R}$ & . do do & 49 & 8.2 & .14 & .00 & 14 & 5. 2 & 360 & 4.2 & 941 \\
\hline & 480 & .71 & Oct. 25,1960 & 54 & 11 & .31 & .00 & 8.6 & 3.5 & 750 & 6.5 & 2,010 \\
\hline 88-84-29ca & 620 & $\mathbf{5 R}$ & Mar. 8,1962 & 53 & 9.4 & .15 & .00 & 9.9 & 17 & 943 & 12 & 1,840 \\
\hline & & & & & & & & & 2.7 & & & \\
\hline
\end{tabular}

See footnotes at end of table. 
water in Sheridan County, Wyo.

indicated. Analyses by U.S. Geol. Survey]

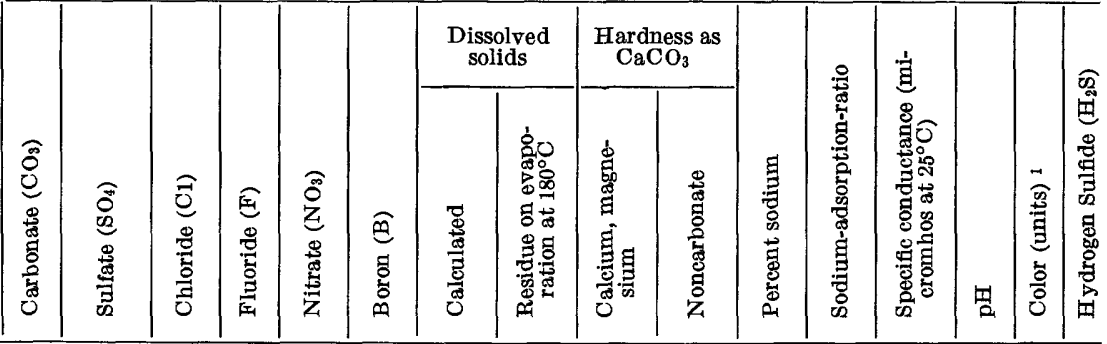

\section{Sandstone}

\begin{tabular}{l|l|l|l|l|l|l|l|l|l|l|l|l|l|l|l}
\hline 0 & 3.0 & 0.0 & 0.1 & 2.4 & 0.04 & $\ldots .$. & 124 & 107 & 2 & 4 & 0.1 & 220 & 7.2 & 3 & $\ldots$ \\
\hline
\end{tabular}

Tensleep Sandstone

\begin{tabular}{|l|r|r|r|r|r|r|r|r|r|r|r|r|r|r|r}
\hline 0 & 5.0 & 0.0 & 0.2 & 0.8 & 0.02 & $\ldots .$. & 202 & 204 & 2 & 0 & 0.0 & 380 & 7.7 & 2 & $\ldots$ \\
\hline
\end{tabular}

\section{Formation}

\begin{tabular}{|l|l|l|l|l|l|l|l|l|l|l|l|l|l|l|l|l}
\hline 0 & 104 & 1.7 & 0.3 & 3.2 & 0.53 & $\ldots . .-$ & 390 & 174 & 0 & 48 & 2.4 & 638 & 8.1 & 0 & $\ldots$ \\
\hline
\end{tabular}

\section{Sandstone}

\begin{tabular}{|l|l|l|l|l|l|l|l|l|l|l|l|l|l|l|l}
\hline 0 & 186 & 1.6 & 0.4 & 0.0 & 0.12 & $\ldots .$. & 550 & 407 & 136 & 13 & 0.6 & 823 & 7.8 & 1 & $\ldots .$. \\
\hline
\end{tabular}

\section{Shale}

\begin{tabular}{l|l|l|l|l|l|l|l|l|l|l|l|l|l|l|l}
\hline 0 & 233 & 30 & 0.2 & 1.0 & 0.06 & $\ldots .$. & 739 & 52 & 0 & 91 & 14 & 1,110 & 7.9 & 1 & $\ldots$ \\
\hline
\end{tabular}

\section{Formation}

\begin{tabular}{|l|l|r|r|r|r|r|r|r|r|r|r|r|r|r|r|r}
\hline 0 & 493 & 42 & 0.3 & 0.3 & 0.12 & 1,300 & 1,320 & 155 & 0 & 84 & 14 & 1,980 & 8.0 & 2 & $\ldots$ \\
6.9 & 157 & 8.1 & .6 & .2 & .13 &..- & \\
\hline
\end{tabular}

\section{Formation}

\begin{tabular}{|c|c|c|c|c|c|c|c|c|c|c|c|c|c|c|c|}
\hline 0 & 1.3 & 24 & 0.7 & 0.1 & 0.11 & 1,540 & 1,560 & 87 & 0 & 93 & 29 & 2,420 & 8.0 & 3 & \\
\hline 0 & .3 & 16 & .7 & .0 & .07 & 1,290 & 1,340 & 62 & 0 & 94 & 29 & 1,990 & 8. 0 & 1 & 0.0 \\
\hline 23 & .3 & 17 & .9 & .0 & .15 & & 1,0 & 23 & 0 & 97 & 36 & 1,570 & 8.3 & 0 & .0 \\
\hline 0 & 4 & 17 & .7 & 0 & .08 & 1,300 & 1,340 & 59 & 0 & 95 & 30 & 2,090 & 8.1 & 4 & .5 \\
\hline 10 & 1.2 & 14 & 1.2 & & & ...... & 530 & 15 & 0 & 96 & 25 & & 8.4 & & .6 \\
\hline 0 & .8 & 16 & 1.6 & & & ........ & 915 & 41 & 0 & 94 & 26 & 1,440 & 8. 1 & & .7 \\
\hline 0 & 136 & 13 & .4 & 13 & .08 & & 690 & 279 & 0 & 50 & 3. 5 & 1,050 & 7.6 & 1 & .5 \\
\hline 0 & 30 & 7.0 & .6 & & & -..... & 484 & 104 & 0 & 73 & 6.0 & 746 & 7.9 & & 1.3 \\
\hline 0 & 2.3 & 7.4 & 2.2 & .0 & .15 & & 1,010 & 30 & 0 & 96 & 32 & 1,570 & 8.2 & 1 & .5 \\
\hline 0 & 708 & 53 & .4 & 1.0 & .16 & 1,550 & 1,5 & 222 & 0 & 8 & 13 & & & 3 & \\
\hline 0 & 2. 0 & 21 & 1.4 & .0 & .12 & 1,340 & 1,340 & 39 & 0 & 96 & 39 & 2,080 & 8. 2 & 3 & .5 \\
\hline 0 & .2 & 7.6 & 1.9 & & -1 & & 1,160 & 32 & 0 & 9 & 37 & & & & .7 \\
\hline 0 & 55 & 23 & 2.1 & & $\ldots$ & & 1,900 & 196 & 0 & 89 & 25 & 3,180 & 7.6 & $\ldots$ & 2.1 \\
\hline 0 & .4 & 57 & 1.8 & & & & & 56 & 0 & 93 & 21 & 1,460 & 8.2 & $=$ & .7 \\
\hline 0 & 1.3 & 9.9 & 2.2 & .0 & .13 & 1,780 & 1,800 & & 0 & 97 & 54 & 2,7 & 8.0 & 1 & .5 \\
\hline 0 & 645 & 10 & 1.9 & & & & 2,38 & & 0 & 95 & 42 & 3,620 & 7.8 & 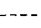 & 1.0 \\
\hline 16 & & & 4.0 & & & & & & & 97 & 33 & & 8.3 & & 1.3 \\
\hline
\end{tabular}


TABLE 4.-Chemical analyses of ground

[Results in parts per million except as

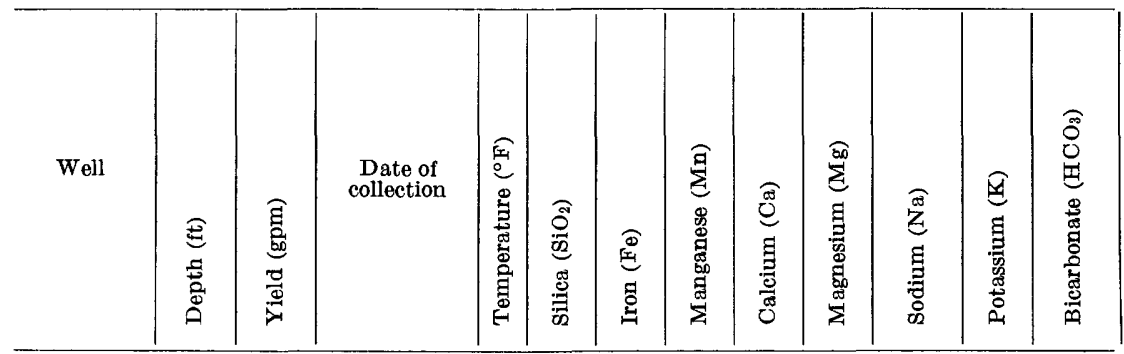

Wasatch

\begin{tabular}{|c|c|c|c|c|c|c|c|c|c|c|c|c|}
\hline $\begin{array}{l}53-79-7 \mathrm{bc} \\
53-80-2 \mathrm{db}\end{array}$ & $\begin{array}{l}280 \\
260\end{array}$ & $2 \mathrm{R}$ & Mar. 7,1962 & $\begin{array}{l}43 \\
54\end{array}$ & ${ }_{10}^{8.1}$ & $\begin{array}{r}0.08 \\
.41\end{array}$ & $\begin{array}{l}0.00 \\
.08\end{array}$ & $\begin{array}{r}6.0 \\
317\end{array}$ & 282 & $\begin{array}{l}252 \\
342\end{array}$ & $\begin{array}{l}2.2 \\
9.8\end{array}$ & $\begin{array}{l}657 \\
591\end{array}$ \\
\hline $18 \mathrm{ca} 2$ & 143 & & Aug. 30,1961 & $\begin{array}{l}04 \\
62\end{array}$ & 8.2 & .05 & .00 & 4.7 & 1.8 & 227 & 1.8 & 500 \\
\hline $2-11 c d$ & 143 & $12 \mathrm{R}$ & Mar. 22, 1962 & 48 & 8.2 & .24 & .00 & 15 & 4.6 & 378 & 3.1 & 1,060 \\
\hline$-7 \mathrm{~d}$ & 42 & $30 \mathrm{R}$ & Aug. 28,1961 & 58 & 13 & .01 & .00 & 34 & 11 & 2.3 & 1.0 & 156 \\
\hline $54-7$ & 121 & 8 & Oct. 26, 1960 & 52 & 8.8 & .26 & .00 & 20 & 5. 1 & 317 & 1.9 & 728 \\
\hline & 120 & & Mar. 22, 1962 & 56 & 30 & 8.1 & & 457 & 403 & 450 & & 627 \\
\hline $14 \mathrm{bc}$ & 110 & $15 \mathrm{R}$ & July 25,1961 & 52 & 11 & .00 & .00 & 46 & 3.2 & 379 & 4.2 & 966 \\
\hline & 60 & $8 \mathrm{R}$ & June 13,1962 & 50 & 21 & 3.7 & .20 & 136 & 36 & 49 & 7.2 & 524 \\
\hline $4-8$ & 245 & $10 \mathrm{R}$ & . do do & 55 & 11 & 1.2 & .00 & 108 & 34 & 567 & 9.5 & 665 \\
\hline & 100 & $10 \mathrm{R}$ & Mar. 8, 1962 & 48 & 9.1 & .03 & .00 & 3. 0 & .0 & 155 & .9 & 345 \\
\hline $54-8$ & 160 & $3 \mathbf{R}$ & Oct. 28,1960 & 52 & 14 & .24 & .00 & 86 & 62 & 22 & 2.4 & 52 \\
\hline $55-79-30$ & 140 & & Oct. 26,1960 & 48 & 9.0 & .93 & .16 & 157 & 77 & 822 & 12 & 680 \\
\hline $30 \mathrm{bb}$ & 200 & $2 \mathrm{R}$ & _._. do & 56 & 8.9 & .41 & .08 & 8.3 & 2.3 & 336 & 4. 6 & \\
\hline $55-81-2$ bc & Spring & & June 14,1962 & 53 & 31 & .03 & .00 & 67 & 10 & 3.4 & 2.9 & 168 \\
\hline $55-8$ & 155 & $10 \mathrm{R}$ & Mar. 7,1962 & 48 & 9.6 & .09 & .00 & 13 & 2.6 & 405 & 3.4 & 1,100 \\
\hline $56-8$ & 378 & $\mathbf{3 R}$ & Oct. 28,1960 & 52 & 10 & .12 & .00 & 3.2 & .5 & 243 & 1.2 & 484 \\
\hline & 87 & $16 \mathrm{R}$ & June 13,1962 & 58 & 7.1 & 25 & .30 & 470 & 519 & 800 & 13 & 801 \\
\hline $57-$ & 95 & $6 \mathbf{R}$ & Aug. 30,1961 & 64 & 5.7 & .00 & .03 & 220 & 136 & 1,140 & 12 & 574 \\
\hline & 160 & 3 & Aug. 29,19 & 52 & 11 & .12 & .00 & 106 & 9.6 & 816 & 6.2 & 473 \\
\hline 57 & 510 & $10 \mathrm{R}$ & Mar. 8,1962 & 39 & 9.1 & .14 & .00 & 6.0 & 1.8 & 350 & 2.8 & 918 \\
\hline
\end{tabular}

Allu-

\begin{tabular}{l|c|c|c|c|c|c|c|c|c|c|c|c|}
\hline $53-80-18 c a 1--$ & 23 & $30 \mathrm{R}$ & Aug. 30, 1961 & 55 & 19 & 0.27 & 0.10 & 201 & 124 & 181 & 13 & 541 \\
$54-84-14 b b$ & 65 & $30 \mathrm{R}$ & June 14,1962 & 56 & 12 & .08 & .00 & 72 & 18 & 12 & 1.2 & 324 \\
$56-82-34 \mathrm{dc}--$ & 56 & $108 \mathrm{R}$ & July 21, 1961 & $\mathbf{4 9}$ & 35 & $\mathbf{4 . 3}$ & .00 & 273 & 136 & 168 & 15 & 613 \\
$57-85-19 \mathrm{ab}-\ldots$ & 30 & 25 & Aug. 28, 1961 & 54 & 12 & .00 & .32 & 103 & 58 & 100 & 2.3 & 441 \\
\hline
\end{tabular}

1 Platinuin-cobalt scale (Hazen, 1892).

$2 \mathrm{R}$ indicates reported yield.

Water from pre-Tertiary rocks is used primarily for domestic and stock purposes. Generally, the water is suitable for domestic use, although the iron content of water from the Tensleep Sandstone and Amsden Formation, the Bearpaw Shale, and the Parkman Sandstone exceeds the recommended limit suggested by the U.S. Public Health Service (1962). Sulfate and dissolved solids in water from well 57-86-34bb, which taps the Lance Formation, also exceed suggested domestic standards, as does the dissolved-solids content of water from the Parkman Sandstone and Bearpaw Shale. Water of suitable quality for irrigation is obtained from the Flathead Sandstone and from the Tensleep Sandstone and Amsden Formation. The Frontier Formation and the Parkman Sandstone yield water that is usable on certain crops under good drainage conditions. Water from the Bear- 
water in Sheridan County, Wyo.-Continued

indicated. Analyses by U.S. Geol. Survey]

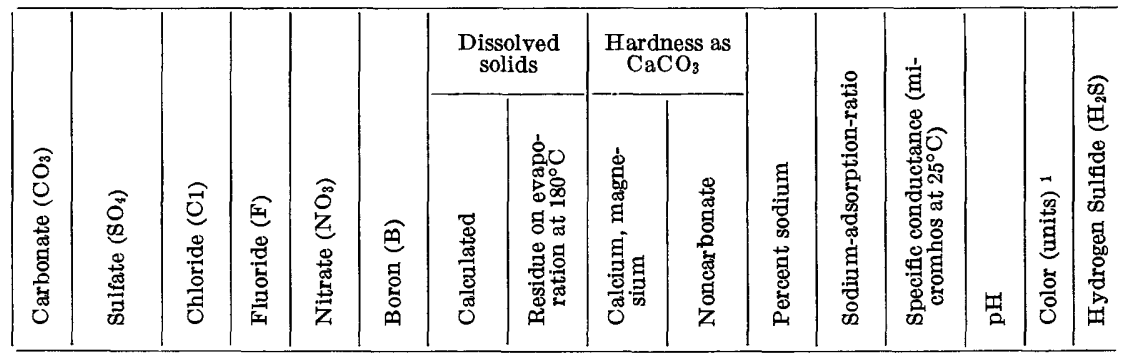

Formation

\begin{tabular}{|c|c|c|c|c|c|c|c|c|c|c|c|c|c|c|c|}
\hline 8.6 & 1.8 & 18 & 1.4 & & & & 613 & 25 & 0 & 95 & 22 & 1.010 & 8.4 & & 2.4 \\
\hline 0 & $990^{\circ}$ & 9.0 & & & & & 3,410 & 1,960 & $1,470^{\circ}$ & 27 & 3.4 & & 7.3 & & 2.9 \\
\hline 0 & 90 & 12 & i. 1 & 8.0 & 0.08 & & 638 & 19 & & 96 & $23^{2}$ & 1,0 & 7.9 & 2 & .6 \\
\hline 0 & 5.4 & 2.0 & 1.0 & & & & 920 & 57 & 0 & 93 & 22 & 1 & 8.0 & & .6 \\
\hline 0 & 1. & .3 & .1 & .5 & .01 & & 160 & 129 & 1 & 4 & .1 & & 7.9 & 2 & \\
\hline 0 & 145 & 2.8 & .9 & .1 & .11 & & 890 & 71 & 0 & 90 & 16 & 1, & 8.1 & 7 & 1.2 \\
\hline 0 & 3,010 & 8.0 & .8 & & & & 4,950 & 2,800 & 2,280 & 26 & 3.7 & & 7. & & .6 \\
\hline 0 & 157 & 2.8 & .4 & 16 & .07 & 1,090 & 1,110 & 128 & 0 & 86 & 15 & & 8. 0 & 0 & 1.2 \\
\hline 0 & 157 & .6 & .4 & & & & 672 & 490 & 60 & 18 & 1.0 & & 7.3 & & .5 \\
\hline 0 & 1,020 & 6.4 & .0 & & & & 2,090 & 408 & 0 & 75 & 12 & 2,91 & 7. & & .6 \\
\hline 17 & 2 & & .6 & & & & & & 0 & 98 & 25 & & & & 1.0 \\
\hline 0 & 64 & 2.0 & .3 & 19 & .18 & & 529 & 470 & 37 & 9 & .4 & 874 & 7.6 & 7 & .... \\
\hline 0 & 1,930 & 6.2 & .3 & 38 & .28 & 3,390 & 3,480 & 709 & 151 & 71 & 13 & & & 4 & $\ldots$ \\
\hline 0 & $\quad 2.8$ & 11 & .8 & 7.9 & .12 & & 830 & 30 & 0 & 95 & 27 & & 7. & 7 & \\
\hline 0 & 37 & 7.0 & .6 & & & & 281 & 209 & 72 & 3. 4 & .1 & & 7. & & 1.2 \\
\hline 0 & .6 & 11 & .8 & & & & 897 & 43 & 0 & 95 & 27 & 1,5 & & & 1.0 \\
\hline 0 & $118^{\circ}$ & 5.7 & 1.8 & 5.6 & .12 & & 628 & 10 & & 98 & 33 & 4 & 8. & 1 & \\
\hline 0 & 4,080 & 45 & .7 & & & & 6,620 & 3,310 & 2,650 & 34 & 6.0 & & 7. & & 4.0 \\
\hline 0 & 110 & 7.4 & .2 & 1.0 & .19 & 4,9 & & 1,110 & 639 & 69 & 15 & & 7. & 6 & .6 \\
\hline 0 & 1,690 & 8.5 & .4 & .8 & .11 & 2,880 & 2,960 & 304 & 0 & 85 & 20 & 3,920 & 8. & 1 & .5 \\
\hline 0 & 3.0 & 16 & $1 . \overline{8}$ & & & & 834 & 22 & 0 & 97 & 32 & 1,320 & 8.2 & & .5 \\
\hline
\end{tabular}

vium

\begin{tabular}{|c|c|c|c|c|c|c|c|c|c|c|c|c|c|c|c|}
\hline $\begin{array}{l}0 \\
0\end{array}$ & $\begin{array}{l}883 \\
8.0\end{array}$ & $\begin{array}{r}8.7 \\
.0\end{array}$ & $\begin{array}{r}0.2 \\
.1\end{array}$ & 0.0 & 0.32 & 1,700 & $\begin{array}{r}1,860 \\
272\end{array}$ & 1,010 & 566 & 28 & 2.5 & $\begin{array}{r}2,250 \\
487\end{array}$ & 7.6 & 8 & 0.6 \\
\hline 0 & 1,020 & 6.1 & .5 & .1 & .22 & 1,960 & 2,060 & 1,240 & 737 & 22.0 & 2.1 & 2,440 & 7.8 & 7 & $\therefore$ \\
\hline 0 & 329 & 4.8 & .2 & 1.1 & .18 & & 844 & 497 & 135 & 30 & 2.0 & 1,220 & 7.7 & 0 & $\ldots$ \\
\hline
\end{tabular}

paw Shale and the Lance Formation is unsuitable for irrigation because of its high sodium (alkali) hazard. The water from preTertiary rocks generally is good for stock use.

\section{DEVELOPMENT}

Bighorn Mountains.-Three water wells are known to have been drilled in the Bighorn Mountains in Sheridan County. Water for stock, summer homes, tourist facilities, and other installations comes mainly from springs or surface water. Aquifers such as the Tensleep Sandstone, Amsden Formation, Madison Limestone, Bighorn Dolomite, and Flathead Sandstone underlie large areas in the mountains ( $\mathrm{pl} .1$ ), but, because most of the area is remote, additional development of water was not needed at the time of the investigation.

Powder River structural basin.-Water from aquifers of preTertiary age has not been extensively developed in the basin in 
Sheridan County. Aquifers that have been tapped by wells are the Amsden Formation and Tensleep Sandstone, Frontier Formation, Parkman Sandstone, Bearpaw Shale, Lance Formation, and possibly the Chugwater Formation. Only two of these formations yield water to more than one well-the Lance (six wells) and the Bearpaw (three wells at Parkman, only one of which is shown on pl. 1). Other potential aquifers yield water only to springs, but artesian supplies could be developed throughout most of the outcrop from the aquifers listed in table 1. Wells drilled some distance from the outcrop of the intended aquifer must necessarily be drilled deeper than those closer to the outcrop because of the steep dip of the formations. Drilling as near the outcrop of the intended aquifer as possible is advisable for this reason; however, a well that is drilled too near the outcrop may not penetrate a maximum saturated thickness.

East of the outcrop area the formations of pre-Tertiary age are deeply buried (fig. 10), and the cost of drilling into them for water wells is great. Ground water possibly may be developed from some "dry" oil-test holes in favorable localities; but the suitability of the water for its intended use should be determined before any such wells are developed.

\section{FORMATIONS OF TERTIARY AGE}

Formations of Tertiary age in the report area include the Fort Union Formation of Paleocene age, the Wasatch Formation of Eocene age, and the White River Formation of Oligocene age. The Fort Union and Wasatch Formations, which are widespread, underlie the central and eastern parts of the county. These units consist of continental deposits made up principally of shale, sandstone, coal, and conglomerate. Conglomerate is not known in the Fort Union in Sheridan County; however, it is in the formation near the mountains to the south, in Johnson County. The White River Formation is present only as isolated remnants in the mountains and is not discussed in the following section.

\section{FORT UNION FORMATION}

The Fort Union Formation is divided into three members in this area: in ascending order, the Tullock Member, Lebo Shale Member, and Tongue River Member. In this report, however, the formation is regarded as undifferentiated.

The following detailed section, which was adapted from Olive (1957, p. 11-12), illustrates the lithology of the upper part of the Fort Union in eastern Sheridan County. 


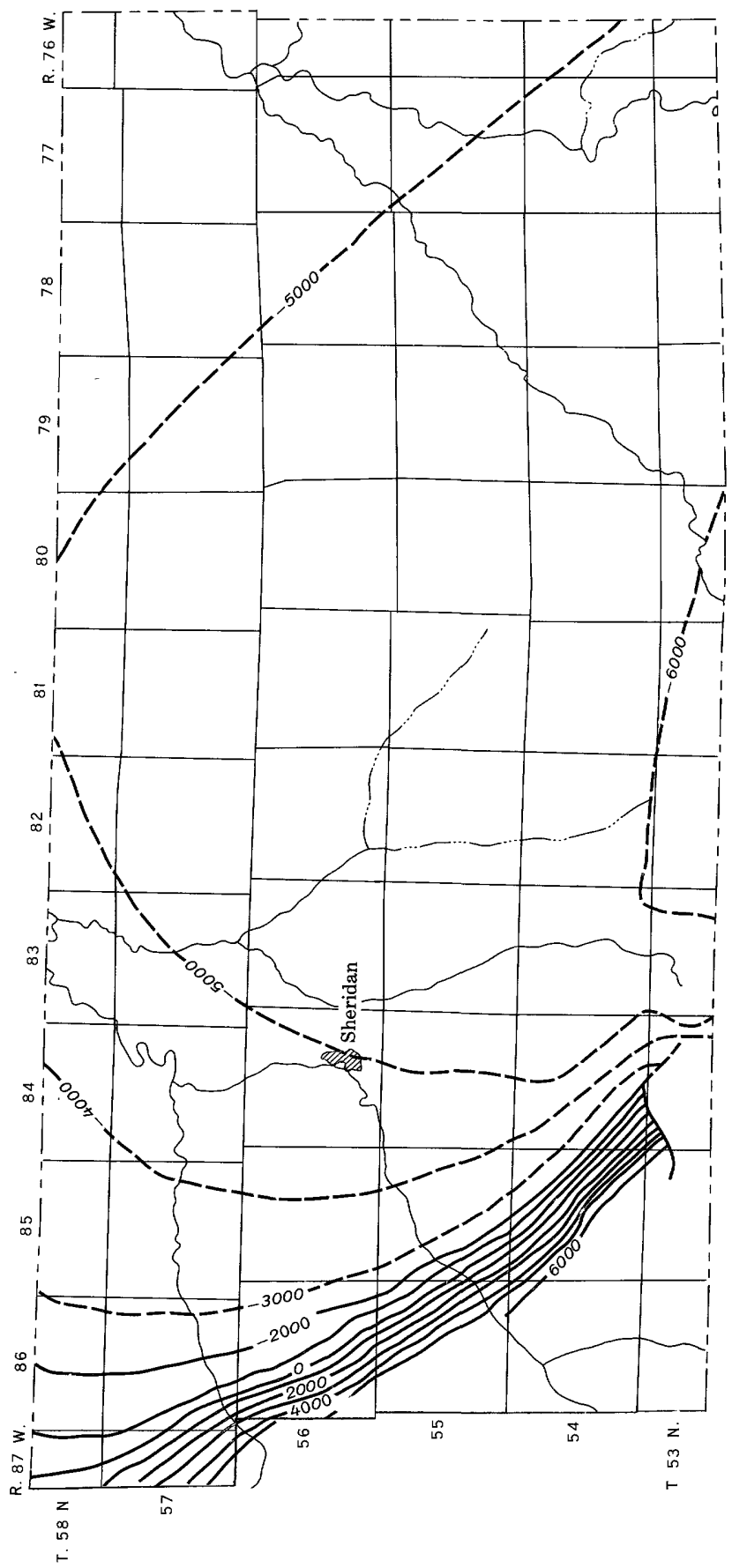

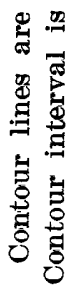

ن.

急

옹

ర)

$\exists$

홍 명

西

몽

견

赵

ช

$\&$ 串

廿

范

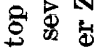

Ф艺

要过

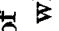

完

द्व

$\Rightarrow$

홇

8 o

承

总

要

范

0 붕

동

연 궁 
Section measured in seo. 25, T. 57 N., R. 77 W., Wyo.

[Adapted from Olive, 1957, p. 11-12]

Wasatch Formation:

Sandstone, medium-grained, friable, yellowish-gray; contains

log-shaped concretions 15-20 ft long-

F'eet Inches

Fort Union Formation :

Shale, dusky-brown

960

Coal

Sandstone, medium-grained, mostly friable, yellowish-gray

Coal

Shale, dusky-brown and gray; interbedded with fine-grained yellowish-gray sandstone

Sandstone, friable, yellowish-gray

Coal with 1-ft shale parting

Sandstone, fine- to medium-grained, friable, yellowish-gray

Shale, dusky-brown

Coal

Shale, dusky-brown

Sandstone medium-orained, friable, vellowish-gras

Coal with shale partings $---{ }^{-}-1$

partings

Shale. dusky-brown

Sandstone, yellowish-gray ; interbedded with light-gray shale_-

Shale, dusky-Brown_._._._._._.

coal

Sandstone and shale, interbedded, gray and yellowish-gray

Sandstone, fine-grained, friable; contains well-indurated zones-

Shale, dusky-brown and black.

Coal

Shale, dusky-brown and black

Sandstone, friable, yellowish-gray ; contains indurated sandstone lenses.......

Coal with 2-ft shale parting

Shale, dusky-brown

Sandstone, fine-grained, friable, yellowish-gray; contains thin layers of dusky-brown shale

Coal

Shale, dusky-brown

Sandstone, fine-grained, friable, yellowish-gray; contains ironstone concretions.

Shale, dusky-brown

Coal

Shale, dusky-brown

Sandstone, fine-grained; contains well indurated zones_

Total measured Fort Union Formation

$\begin{array}{rr} & 5 \\ 2 & 4 \\ 43 & 10 \\ 1 & 8\end{array}$

$7 \quad 1$

420

39

$24 \quad 0$

36

$5 \quad 7$

$3 \quad 1$

280

45

44

$28 \quad 0$

73

$7 \quad 10$

$58 \quad 6$

$47 \quad 9$

60

17

66

22 0

171

$9 \quad 6$

$42 \quad 0$

9

The contract between the Fort Union Formation and the underlying Lance Formation is apparently conformable and gradational throughout Sheridan County. In the western part of the county, the Fort Union Formation dips about $4^{\circ}$ E. or SE. (Taff, 1909, p. 
132) and is probably about 2,000 feet thick. The strata in the Spotted Horse coal field in the eastern part of the county generally dip southwestward at less than $3^{\circ}$ (Olive, 1957, p. 21). There, the thickness of the formation is not known; only 900 feet of the upper part of the Fort Union is exposed (Olive, 1957, p. 10).

\section{WASATCH FORMATION}

Near the mountains, the Wasatch Formation is divided into two members on the basis of an angular unconformity. The lower member is the Kingsbury Conglomerate Member, and the upper is the Moncrief Member. Both members, which are interpreted as alluvial-fan deposits (Gale and Wegemann, 1910, p. 144; Sharp, 1948, p. 12), grade laterally into the fine-grained facies of the Wasatch Formation and cannot be distinguished a few miles east of the mountains.

The Kingsbury Conglomerate Member is exposed in a small area at the base of Moncreiffe Ridge but is not shown on plate 1 . It is about 800 feet thick just south of the report area (Mapel, 1959, p. 64).

The Moncrief Member is as much as 1,400 feet thick (Sharp, 1948, p. 2) and consists of beds of conglomerate, coarse-grained sandstone, and greenish-gray siltstone. Precambrian rocks of the Bighorn Mountains were the source of most of the material in the member, and boulders 5-10 feet in maximum dimension are common in the upper part of the member, which contains relatively coarser material than the lower part.

In the Powder River structural basin, the lithologies of the Wasatch and the Fort Union Formations do not differ greatly. Coal is not as prevalent in the Wasatch, nor is sandstorie. (See measured sections by Olive, 1957, p. 11-12, 16-18.) The maximum thickness of the formation in the basin is about 1,200 feet (Taff, 1909, p. 130).

The following section (adapted from Mapel, 1959, p. 67) was measured 3 miles south of the project area, but it illustrates the similarity between the Wasatch and Fort Union Formations.

Partial section of coal-bearing beds of Wasatch Formation in $\mathcal{S}^{1 / 2}$ sec. $31, T$. $53 N ., R .80 \mathrm{~W}$.

Feet Inches

Clinker, red

30

Shale and sandstone, interbedded; sandstone very light gray to grayish yellow, fine grained to silty, friable; shale, gray ; interval poorly exposed

660

Shale, dusky-brown, carbonaceous

36

Concealed; probably sandstone and shale

350

Sandstone, very light gray, fine-grained, calcareous, crossbedded; interbedded greenish-gray siltstone near base 
Partial section of coal-bearing beds of Wasatch Formation in $\mathbb{S}^{1 / 2}$ sec. $31, T$. 53 N., R. 80 W.-Continued

Concealed.

Feet Inches

Shale, light-olive-yellow

Coal and interbedded brown shale

150

120

130

Sandstone and shale, interbedded; sandstone, white, fine-grained, friable; shale, gray

Coal

Shale, light-olive-gray; grades upward into dusky brown shale in top $3 \mathrm{ft}$

Shale, dusky-brown, carbonaceous

Coal

Shale, dusky-brown, carbonaceous

6

Sandstone and shale, interbedded, very light gray, fine-grained, calcareous; shale, olive gray; bed of gray, yellowish-weathering, sandy limestone concretions $8 \mathrm{ft}$ above base

Shale, dark-gray ; contains a few shell fragments near base

Limestone, light-gray; weathers yellowish brown; composed largely of shells of fresh-water mollusks

Coal

Shale, gray ; upper 8 in. is dusky brown

Shale, dusky-brown, carbonaceous; contains a few $1 / 2$-in. seams of coal.

Shale, gray, slightly carbonaceous

Coal

Concealed.

$$
0
$$

$\begin{array}{rr} & 4 \\ 1 & 6 \\ 19 & 0\end{array}$

Sandstone, light-gray, fine-grained; contains a few yellowish-gray limestone concretions.

\section{Concealed}

Shale, dusky-brown, carbonaceous

Coal.

Shale, dusky-brown, carbonaceous_._-_._.

Sandstone, very light gray, fine-grained, friable; contains a few thin partings of gray shale

Shale, dusky-brown, carbonaceous

Coal

Shale, dusky-brown, carbonaceous

Shale, olive-gray ; sandy near top_...-.

Coal, shaly

Shale and sandstone, interbedded ; shale, olive gray ; sandstone, very light gray, fine grained, friable, crossbedded

Shale, dusky-brown, carbonaceous; contains a few 1/2-in. seams of coal

Shale, olive-gray; sandy near base

Sandstone, very light gray, fine-grained, friable, crossbedded

Shale, dusky-brown, carbonaceous

Coal

Shale, dusky-brown, carbonaceous

30

Sandstone, light-gray to light-yellowish-gray, very fine grained, friable; upper $3-4 \mathrm{ft}$ shaly 
Partial section of coal-bearing beds of Wasatch Formation in $S^{1 / 2}$ sec. 31, T. $53 \mathrm{~N} ., \mathrm{R} .80 \mathrm{~W}$.-Continued

Feet Inches

Coal

Shale, dusky-brown, carbonaceous

Sandstone, light-yellowish-gray, very fine grained; contains many partings of gray shale

Shale, olive-gray; 1-in. seam of coal near top.

Sandstone, very light gray, friable

Coal.

Shale, dusky-brown, carbonaceous

Concealed.

Sandstone, gray to white, fine-grained, crossbedded ; shaly near top

Shale, dusky-brown, carbonaceous

Shale, gray, silty

$7 \quad 0$

16

50

9

16

240

110

30

30

Total measured thickness

5216

The top of the Roland coal is used as the arbitrary boundary between the Fort Union and Wasatch Formations and has been traced throughout much of the basin. Attempts to determine the relation between the Roland coal and the Kingsbury Member at Moncreiffe Ridge have been unsuccessful, and the Wasatch is apparently conformable with the Fort Union throughout most of Sheridan County. Olive (1957, p. 13-14) noted an erosional unconformity in the Spotted Horse coal field in Campbell County, where 670 feet of interbedded sandstone, shale, and coal, including the Roland coal, was replaced by 160 feet of crossbedded sandstone. A conglomeratic mudstone was noted some 150 feet above the Fort Union-Wasatch contact west of Clear Creek in T. 55 N., R. 78 W., and is at about the horizon where Brown (1948, p. 1273) postulated that evidence of an unconformity might be found. A similar conglomerate was noted in the Badger Hills, but the relation to the Roland coal is not known.

\section{WATER-BEARING PROPERTIES}

Water levels generally are not deep in the Fort Union and Wasatch Formations. The level in most wells is less than 100 feet, and the maximum measured depth to water was 222 feet in well 57-80-34cc. Wells, even on the drainage divide between the Powder River and the Tongue River, penetrate aquifers at shallower depths than might be expected, because many of the aquifers are lenticular and are recharged locally. In areas of considerable local relief, however, the upper strata may be drained. Flowing wells are common in the valleys of the Powder River, Tongue River, and Little Goose Creek. The location of wells and depth to water are shown on plate 1. Generally, wells drilled in valleys and draws will have higher water levels, 
with respect to land surface, and may penetrate aquifers at shallower depths.

Depths of wells range considerably because the aquifers are not continuous. The lenticularity of some of the aquifers and the resulting difference in depth of wells are shown in figure 11. The profile is near the western margin of the Wasatch Formation, and the deeper wells are probably completed in the Fort Union. The specific conductance of water from the wells also is shown in figure 11. The difference in conductance that occurs within a short distance indicates that the aquifers are not directly connected. The sandstone aquifers are probably deposits similar to the channel sandstone shown in figure 12 .

General correlations are possible on the basis of the known intervals between the coals in localities where several coal beds are penetrated by wells (fig. 13). The aquifers that yield water to wells are usually the only ones noted in the drillers' logs, and although some sands are noted as being dry, probably not all the sand beds above those which contribute water to the wells are dry. Wells commonly are drilled deeper in an attempt to develop them as flowing wells or to reach water of more acceptable quality.

Yields from wells are generally small-less than $10 \mathrm{gpm}$-but supplies adequate for domestic and stock use can be obtained throughout the area. No water wells are known to penetrate the entire thickness of either the Fort Union or Wasatch Formations, but the yield of wells could be substantially increased if by drilling deeper, a greater number of aquifers were penetrated. The principal aquifers that yield water to wells and springs are sandstone and coal. Large amounts of water accumulate in abandoned coal mines, and this water has been developed from springs (53-82-10aa) at old mine entrances and from wells (53-82-2da) bored into flooded mine workings.

Numerous springs exist in the Powder River structural basin, and springs with flows as small as $0.1 \mathrm{gpm}$ have been developed. Contact springs are the most common, although a few landslide springs occur. In addition to the aquifers previously mentioned, clinker bedscreated by the burning of coal seams - commonly yield water to springs that is less mineralized than is the water from other aquifers.

Although the resistant-Moncrief Member of the Wasatch Formation forms an area of high relief and is largely above the water table, the occurrence of water in the Moncrief is similar to the occurrence in alluvial fans. Water-table conditions exist in the recharge area, and artesian conditions occur basinward. Springs near Moncreiffe Ridge issue from sandstone and conglomerate lenses that have been exposed by post-Eocene erosion. 


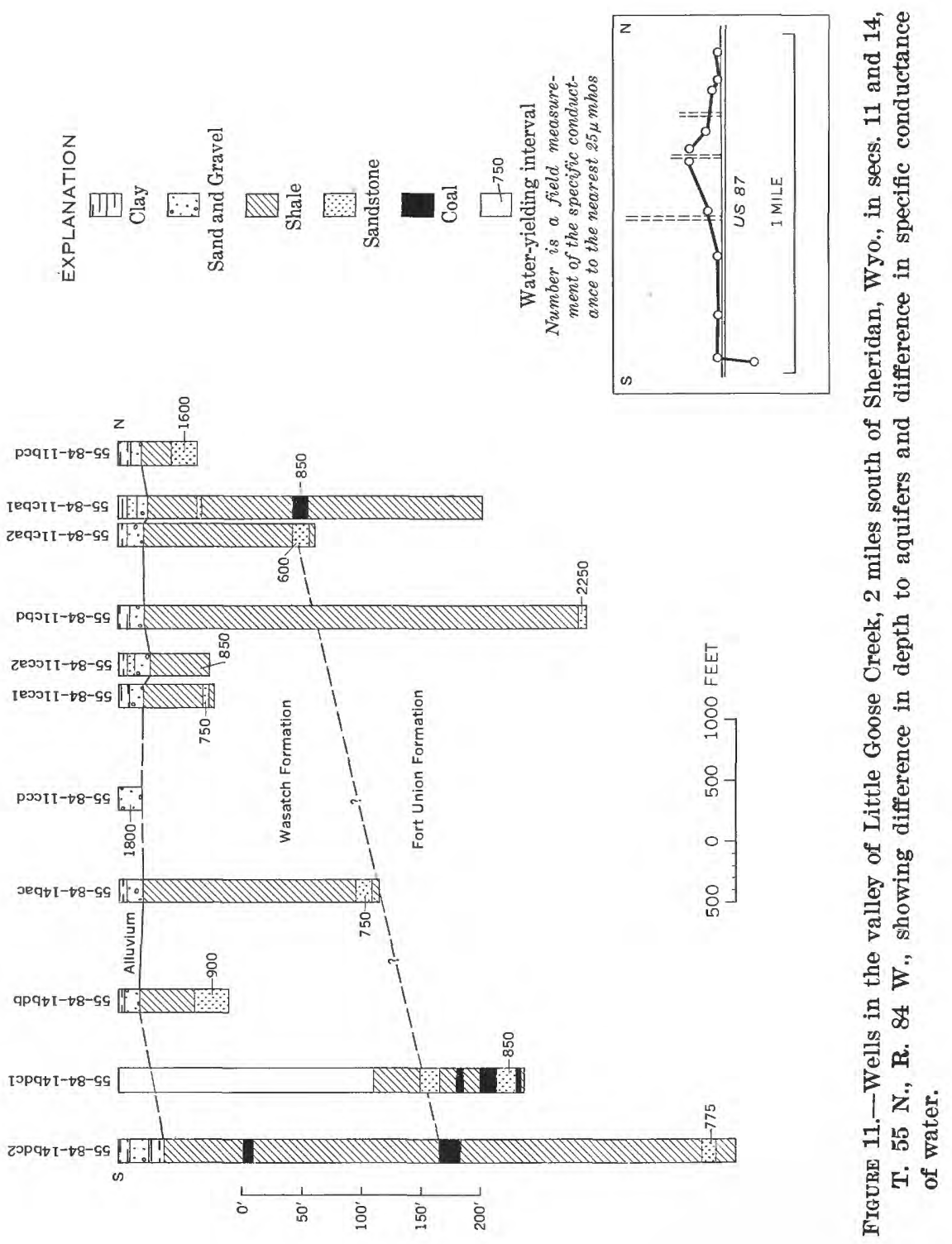




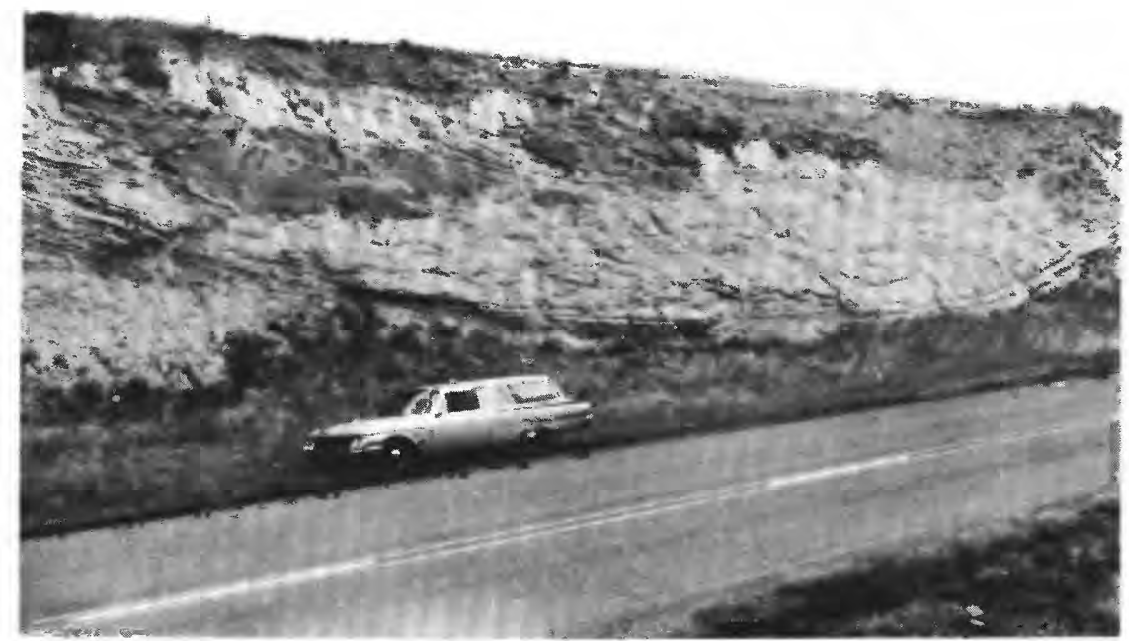

FIGURE 12.-Channel sandstone in the Fort Union Formation exposed in a roadcut in sec. 34, T. 57 N., R. 84 W.

Drillers' logs show that sandstone and coarser material constitute at least 50 percent of the bedrock penetrated near Moncreiffe Ridge Therefore, moderate to large yields might be obtained from deep wells near Moncreiffe Ridge. These bedrock conditions extend basinward as far as wells 54-83-7ad and 54-83-21cc. The sandstone penetrated by well $54-83-27 \mathrm{~cd}$, which is just east of these two wells, was only 30 percent of the bedrock. Although this well may have penetrated a greater saturated thickness of sandstone than did some of the shallower wells to the west, the basinward decrease in permeability has resulted in a specific capacity for the well of less than $0.01 \mathrm{gpm}$ per foot of drawdown.

\section{RECHARGE AND DISCHARGE}

Recharge to the aquifers in the eastern and central parts of the county is almost entirely from precipitation. Areas underlain by clinker beds are especially favorable for recharge, because precipitation on these areas percolates rapidly down through the zone where it would evaporate or be transpired.

Recharge in the western part of the project area and along Piney Creek comes principally from irrigation and surface water. Ground water, nonetheless, probably contributes to the flow of Piney Creek in some reaches. 


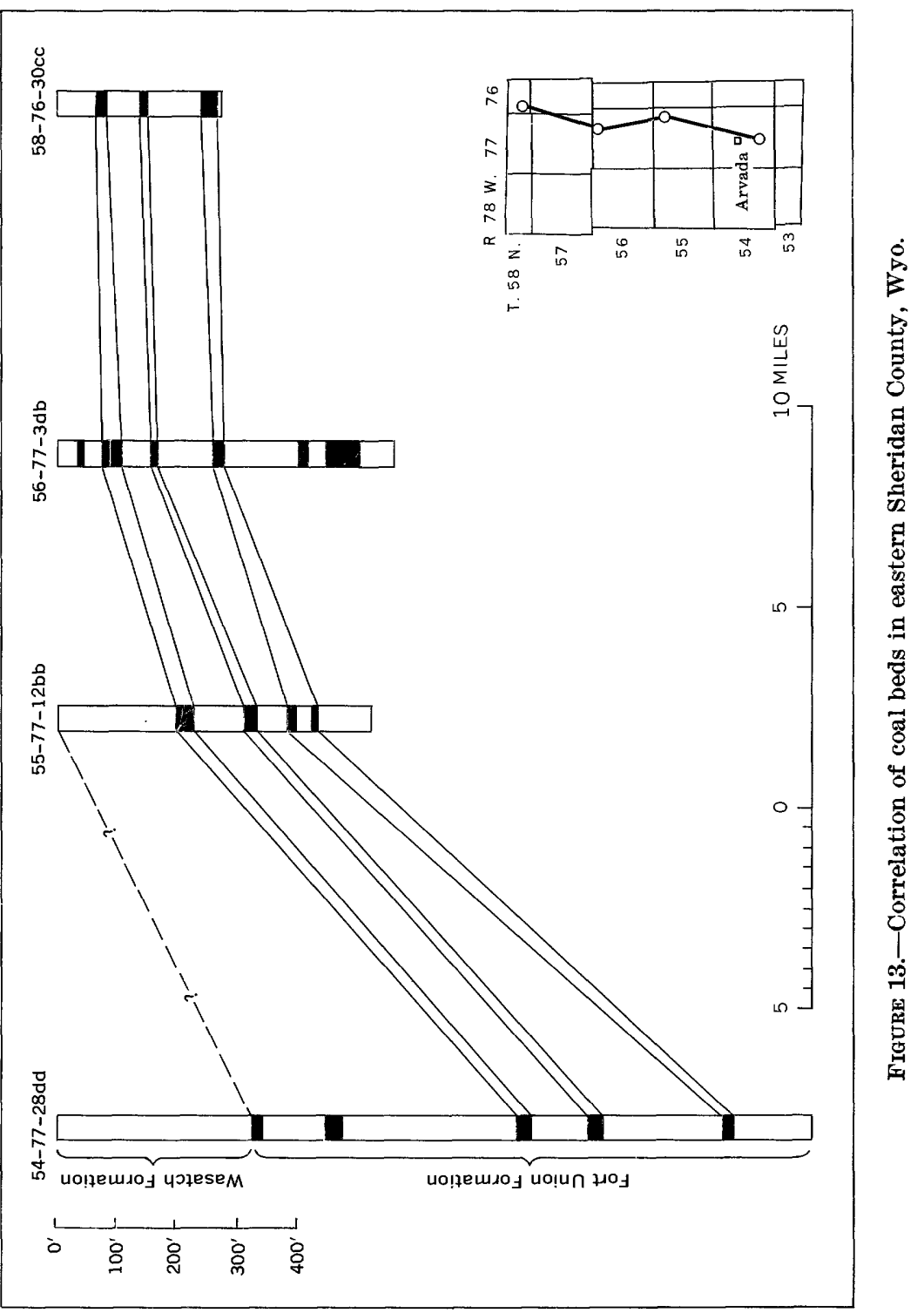




\section{QUALITY OF WATER FROM THE FORT UNION FORMATION}

Chemical analyses of 17 water samples from the Fort Union Formation are given in table 4 . The wells sampled were in, or near, the outcrop of the formation. The water is a sodium bicarbonate type and has a dissolved-solids content that ranges from 484 to $2,380 \mathrm{ppm}$. The iron content ranges from 0.08 to $3.2 \mathrm{ppm}$, and the hardness ranges from 15 (soft) to $279 \mathrm{ppm}$ (very hard). The chemical characteristics of water from the Fort Union are presented graphically in figure 14. The quality of water in the Fort Union Formation probably is affected by two chemical reactions as the water moves through the rocks. The reactions are as follows:

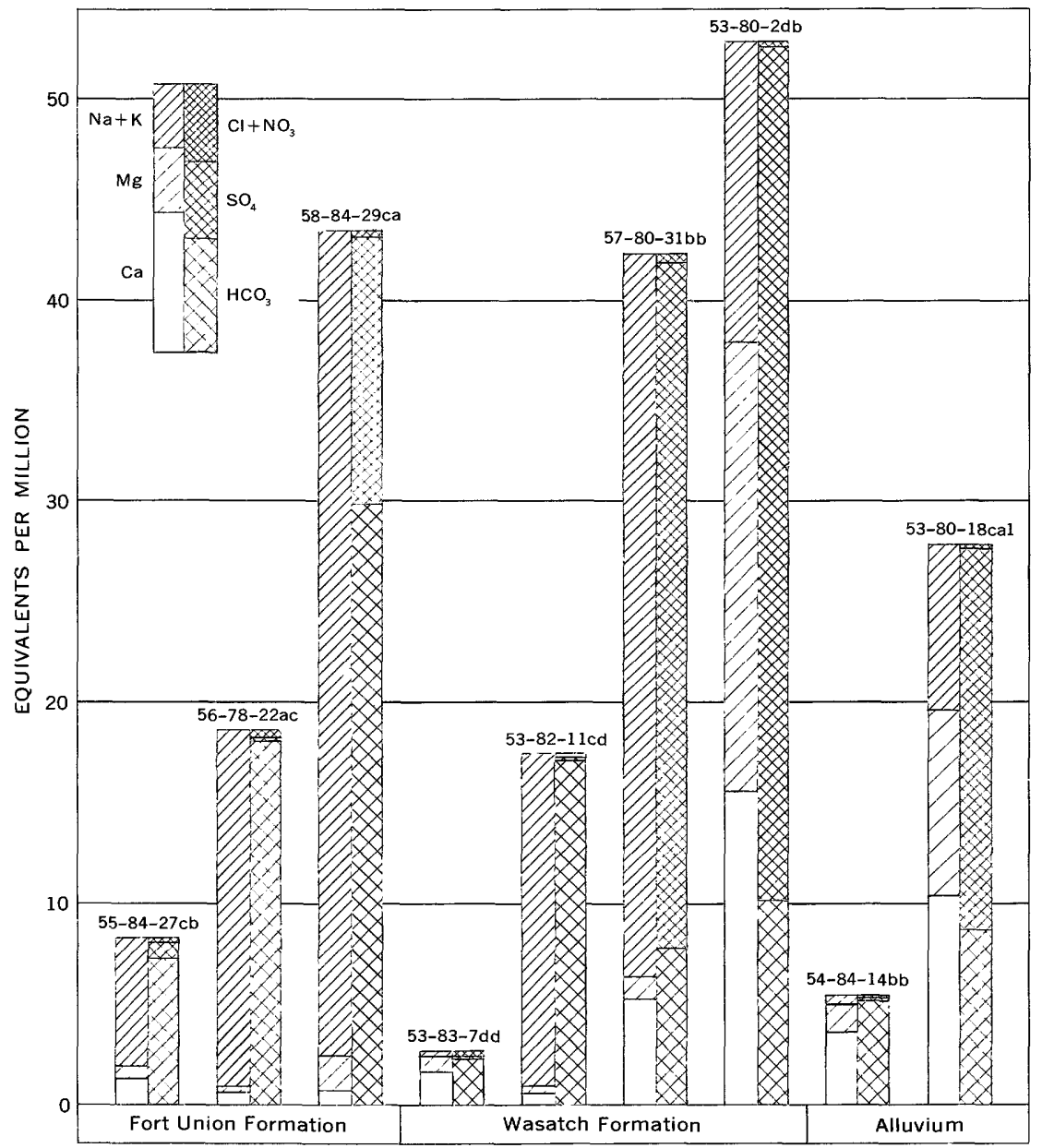

Figuke 14.-Chemical characteristies of ground water in the Fort Union and Wasatch Formations and in the alluvium, Sheridan County, Wyo. 
1. Cation-exchange softening.-Many rock materials hold absorbed cations that may be exchanged for cations in solution in water. One such reaction is the exchange of sodium (held by the solid phase) for dissolved calcium. Generalized, it may be written

$$
2 \mathrm{Na} X+\mathrm{Ca}^{+2} \rightarrow \mathrm{Ca} X_{2}+2 \mathrm{Na}^{+1},
$$

where $\mathrm{X}$ represents a unit of exchange capacity in the solid-phase material. Riffenburg (1925) cited cation-exchange softening as affecting the quality of water in the Fort Union Formation in Montana; similar conditions occur in Wyoming.

2. Sulfate reduction.-In the presence of hydrocarbons and certain bacteria, sulfate may be reduced to form hydrogen sulfide and bicarbonate. The reaction was illustrated by Hem (1959, p. 103) as follows:

$$
\begin{gathered}
\mathrm{CaSO}_{4}+\mathrm{CH}_{4} \rightarrow \mathrm{CaS}+\mathrm{CO}_{2}+2 \mathrm{H}_{2} \mathrm{O} \\
\mathrm{CaS}+2 \mathrm{CO}_{2}+2 \mathrm{H}_{2} \mathrm{O} \rightarrow \mathrm{H}_{2} \mathrm{~S}+\mathrm{Ca}\left(\mathrm{HCO}_{3}\right)_{2} .
\end{gathered}
$$

The reduction of sulfate in water in the Fort Union Formation is indicated by the presence of relatively high bicarbonate concentrations as compared to the sulfate concentrations, and by hydrogen sulfide and hydrocarbon gases in the water at many locations. Only one water sample had a sulfate concentration higher than the bicarbonate concentration, and that sample was obtained from a shallow well (56-85-3ad).

Although cation-exchange softening is the probable cause of the high percentage of sodium in the water of the Fort Union Formation, sulfate reduction possibly indirectly increases the percentage of sodium. Under favorable conditions the reduction of sulfate will result in the formation of nearly insoluble calcium and magnesium carbonates, which precipitate (Eaton, 1936, p. 515).

Foster (1950) suggested that carbon dioxide which originates in carbonaceous material promotes high sodium bicarbonate concentrations in water. The carbon dioxide, when adsorbed by water, enables the water to dissolve calcium carbonate, and an increase in bicarbonate concentration results. If water that contains calcium carbonate comes in contact with cation-exchange materials, the dissolved calcium may be exchanged for sodium. The exchange not only increases the proportion of sodium in solution, but allows even greater amounts of bicarbonate to be held in solution.

Water from the Fort Union Formation is used principally for domestic and stock purposes. The dissolved-solids content of water from all but one well exceeded the limit recommended by the Public Health Service. The water is usable, however. Iron exceeds the 0.3ppm suggested maximum in water from some aquifers. Most wells 
yield soft to moderately hard water. Hydrogen sulfide imparts an unpleasant odor to some of the supplies, but, like carbon dioxide, it is not physiologically harmful in water. At the time of this investigation (1961), water from the Fort Union Formation was not being used for irrigation, and it generally would not be usable as irrigation water except for salt tolerant crops under favorable conditions. Nearly nine-tenths of the samples analyzed had either a high to very high sodium hazard or a high to very high salinity hazard. Water from the Fort Union Formation ranges from good to fair for stock use.

\section{GAS ASSOCIATED WITH WATER IN THE FORT UNION FORMATION}

Gas and water are discharged together from some wells that penetrate coal and other carbonaceous material of the Fort Union Formation. Samples of gas were collected at the well head from four flowing wells in accordance with techniques suggested by the Chemical and Geological Laboratories, Casper, Wyo. Analyses were made by that laboratory using a gas chromatograph. These analyses, together with measurements of the quantity of gas discharged, are given in table 5. The gas is mainly methane with lesser qantities of oxygen, nitrogen, carbon dioxide, ethane, propane, isobutane, and higher paraffin hydrocarbons. Hydrogen sulfide is present, although its quantity could not be determined by the chromatographic analysis. The concentration of hydrogen sulfide dissolved in the water at the well head was determined, however. (See table 4.)

Most of the gas probably originates in the coal or other carbonaceous material in the Fort Union Formation. Analyses of gas from coal (Chamberlin, 1909) are similar in many respects to analyses of gas obtained from water wells in Sheridan County. Lewis (1934) stated

TABLE 5.-Quantity and quality of gas discharged with water from the Fort Union Formation, Sheridan County, Wyo.

[Analyses by Chemical and Geological Laboratories, Casper, Wyo.]

\begin{tabular}{|c|c|c|c|c|c|c|c|c|c|}
\hline \multirow[b]{2}{*}{ Well } & \multirow[b]{2}{*}{ Date } & \multirow{2}{*}{$\begin{array}{c}\text { Gas- } \\
\text { water } \\
\text { ratio } 1 \\
\text { (at } 25^{\circ} \mathrm{C} \\
\text { and } \\
\text { atmos- } \\
\text { pheric } \\
\text { pres- } \\
\text { sure) }\end{array}$} & \multicolumn{7}{|c|}{ Percentage composition (by volume) } \\
\hline & & & $\begin{array}{l}\text { Oxy- } \\
\text { gen } \\
\left(\mathrm{O}_{2}\right)\end{array}$ & $\begin{array}{l}\text { Nitro- } \\
\text { gen } \\
\left(\mathrm{N}_{2}\right)\end{array}$ & $\begin{array}{c}\text { Carbon } \\
\text { dioxide } \\
\left(\mathrm{CO}_{2}\right)\end{array}$ & $\begin{array}{c}\text { Me- } \\
\text { thane } \\
\left(\mathrm{CH}_{4}\right)\end{array}$ & $\begin{array}{r}\text { Ethane } \\
\left(\mathrm{C}_{2} \mathrm{H}_{6}\right)\end{array}$ & $\begin{array}{c}\text { Pro- } \\
\text { pane } \\
\left(\mathbf{C}_{3} \mathrm{H}_{8}\right)\end{array}$ & $\begin{array}{l}\text { Isobutane } \\
\left(\mathrm{C}_{4} \mathrm{H}_{10}\right) \\
\text { and } \\
\text { higher } \\
\text { paraffin } \\
\text { hydro- } \\
\text { carbons }\end{array}$ \\
\hline $\begin{array}{l}54-76-5 a c- \\
54-77-5 \mathrm{db}-\ldots \\
57-76-20 \mathrm{bd}- \\
58-82-30 \mathrm{a} a\end{array}$ & $\begin{array}{l}\text { Aug. } 29,1961 \\
\text { Aug. } 30,1961 \\
\text { Mar. } 21,1962\end{array}$ & $\begin{array}{r}(2) \\
0.5 \\
.3 \\
2.2\end{array}$ & $\begin{array}{r}0.14 \\
.63 \\
4.82 \\
1.03\end{array}$ & $\begin{array}{r}8.87 \\
8.69 \\
23.13 \\
6.14\end{array}$ & $\begin{array}{l}0.31 \\
.47 \\
.78 \\
.94\end{array}$ & $\begin{array}{l}90.66 \\
90.10 \\
71.18 \\
91.82\end{array}$ & $\begin{array}{l}0.02 \\
.08 \\
.07 \\
.07\end{array}$ & $\begin{array}{r}\text { Trace } \\
0.03 \\
.02 \\
\end{array}$ & $\begin{array}{l}\text { Trace. } \\
\text { Trace. } \\
\text { Trace. }\end{array}$ \\
\hline
\end{tabular}

1 Gas-volume discharge (liters)/water-volume discharge (liters).

2 Water discharge not measurable. 
that carbon dioxide and methane in coal are being formed continuously, primarily by internal molecular adjustments during transitions from rank to rank in the coal series. Ethane and propane have been obtained from coal, but generally as a result of heating. To the authors' knowledge, isobutane has not been cited specifically as a gas formed or contained in coal. Many analyses of gas contained in coal were made several years ago when analytical procedures were less sensitive to small quantities of paraffin hydrocarbons. Isobutane may have been present, therefore, in gas contained in coal, but not detected when the gas was analyzed. Although coal and carbonaceous material of the Fort Union Formation are probably the principal sources of the gases discharged from water wells, the isobutane and the higher paraffin hydrocarbons may be natural gases that have migrated from other rocks. Some of the ethane and propane also may have migrated from natural-gas deposits. Natural gas generally contains a higher percentage of ethane and propane than does the gas obtained from coal.

Moore (1950) stated that the nitrogen in coal comes partly from plant constituents but mainly from air imprisoned in the coal. However, some of the nitrogen discharged with the water from wells in Sheridan County may have been carried downward by percolating ground water. Most of the oxygen from air imprisoned in coal probably combines with carbon and hydrogen during the alteration of vegetal matter from which the coal is formed. Oxygen, nevertheless, has been obtained from coal, and Lewis (1934, p. 33) stated that free oxygen in small quantities is sometimes detected in coal. The oxygen in gas obtained from water wells may have been present in percolating ground water that was once in contact with the atmosphere.

Despite the facts that oxygen and nitrogen have been observed in coal and that both may be present in percolating ground water, the oxygen, and some of the nitrogen in the samples, possibly resulted from air contamination while the samples were being collected. The evacuated tanks used to collect gas samples may have leaked slightly during the interval between evacuation and sample collection. Also, some of the well casings are old and corroded, and air may have entered the casings. Air contamination of the gas from well 57-76-20bd seems probable. If the analysis of gas from well 57-76-20bd is recomputed to air-free conditions, methane content increases to greater than 90 percent, and nitrogen decreases to approximately 7 percent. Thus, recomputed on this basis, the analysis of the gas is similar to analyses of gas from the other wells.

The total volume of gas discharged per unit volume of water discharged - that is, the gas-water ratio-differs from well to well. Well 
58-82-30aa has a gas-water ratio of 2.2 , whereas wells $54-77-5 \mathrm{db}$ and 57-76-20bd have gas-water ratios of 0.5 or less. Although a sample of gas was obtained from well 54-76-5ac, the gas-water ratio could not be measured. Field observations indicated that the gas-water ratio for this well is greater than that of any other in the project area. This well discharges gas and water in alternating surges.

Gas accumulates in fractures in the coal, and it also migrates to adjacent strata. Gas in an aquifer affects the height to which water will rise in a well and may bring the water to the surface (Meinzer, 1942, p. 418). Where the quantity of gas in an aquifer is small, all the gas may be dissolved in the water. A gradual decrease in pressure as the water moves from the aquifer allows the dissolved gas to be liberated. The liberated gas expands, and as it expands the specific gravity of the gas-water mixture is decreased and a lifting action created. Several wells in Sheridan County flow because of this effect that otherwise probably would not. Other wells in Sheridan County undoubtedly flow because of the pressure of free gas in the aquifer.

A 1-liter sample of water was obtained from well 58-82-30aa to determine the quantity. and quality of gas in solution at the well head. The sample was allowed to stand unsealed at atmospheric pressure until all visible gas bubbles had disappeared (approximately 1 min.). It then was sealed tightly. The sample yielded 64 milliliters of gas (measured at $25^{\circ} \mathrm{C}$ ) when analyzed. The percentage composition of this gas was as follows:

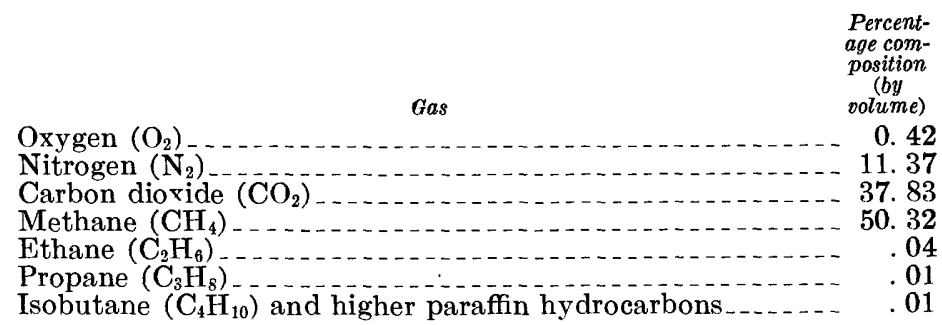

Each type of gas was dissolved in the water in a quantity not exceeding its solubility at atmospheric pressure and at the same water temperature as when the sample was collected. The gases probably remain in the water for some time and gradually escape when the water is in contact with the atmosphere. The escape probably is more rapid when the water is agitated by flowing or by some other action. Literature could not be found that cited harm to human beings or stock as the result of drinking water containing the quantities of hydrocarbon gases likely to be in solution at atmospheric pressure. 


\section{QUALITY OF WATER FROM THE WASATCH FORMATION}

Chemical analyses of water from the Wasatch Formation are given in table 4. The chemical characteristics of the water are illustrated graphically in figure 14. The dissolved-solids content of the water ranges from 160 to $6,620 \mathrm{ppm}$; iron content, from 0.00 to $25 \mathrm{ppm}$; sulfate content, from 0.6 to $4,080 \mathrm{ppm}$; and hardness, from $8 \mathrm{ppm}$ (soft) to $3,310 \mathrm{ppm}$ (very hard). Hydrogen sulfide, methane, and probably the higher paraffin hydrocarbon gases are in the water of the Wasatch Formation, particularly in areas underlain by coal. No analyses of gas were made, however, because of unsuitable sampling conditions.

Approximately half the wells sampled yield a sodium bicarbonate type water with less than 1,200 ppm dissolved-solids content. The water from these wells is similar to that from the Fort Union Formation and probably has been affected by cation-exchange softening and sulfate reduction. Deposits of both formations are similar, and, therefore, water of similar quality would be expected, particularly from deep wells.

Water from other wells sampled ranges widely in dissolved-solids content. Sodium sulfate, magnesium-sodium sulfate, magnesiumcalcium sulfate, and calcium bicarbonate types of water occur. This diversity may be attributed to local differences in recharge conditions, soils, and lithology. A sample of water from clinker beds (spring 55-81-2bc) was of calcium bicarbonate type and had a dissolved-solids content of $281 \mathrm{ppm}$.

Water from the Wasatch Formation is used principally for domestic and stock purposes. The dissolved-solids content of the water generally exceeds the limit recommended by the Public Health Service, but the water is usable at most locations. Undesirable concentrations of iron, manganese, and sulfate are mainly in water having a dissolvedsolids content greater than 2,000 ppm. Water from well 54-79-21bdd, the public supply of the town of Clearmont, has a dissolved-solids content of $890 \mathrm{ppm}$, is moderately hard, and contains sufficient hydrogen sulfide to impart a noticeable odor. Although wells having sufficient yield may be constructed in the Wasatch Formation, the water is generally unusable for irrigation except on the most salttolerant crops under the most favorable conditions. Approximately two-thirds of the analyzed water samples had either a very high salinity hazard or a very high sodium hazard. The water ranges from good to very poor as a stock supply. Wells at most locations, however, yield usable stock water. 


\section{DEVELOPMENT OF WATER FROM ROCKS OF TERTIARY AGE}

Water supplies for stock and domestic use have been developed throughout the eastern and central parts of the county from the Fort Union and the Wasatch Formations. Wells shown on plate 1 do not indicate their density but were selected as representative of those in the area.

Small yields are available throughout the area underlain by these formations, but moderate to large supplies possibly could be developed from wells in the vicinity of Moncreiffe Ridge.

\section{DEPOSITS OF QUATERNARY AGE}

Those deposits of Quaternary age in Sheridan County that contain significant quantities of water are terrace, alluvium, and flood-plain deposits. The water-bearing characteristics of these and other deposits of Quatemary age are given in table 1. Terraces of Tertiary age have been mapped in the area by Mapel $(1959, \mathrm{p} .74)$. In this report, however, the terrace deposits are generalized and are shown on the map as Quaternary age.

\section{TERRACE DEPOSITS}

Terrace deposits occur along the major streams throughout the county. They are more prevalent in the western part of the county, and only these terrace deposits are shown on plate 1 . Some of these contain significant quantities of water. The deposits, which consist of unconsolidated clay, silt, sand, gravel, and boulders, are as much as 45 feet thick.

\section{FLOOD-PLAIN DEPOSITS}

Flood-plain deposits, which are shown on plate 1, comprise floodplain material, slope wash, and the Recent terrace deposits which were described by Leopold and Miller (1954, p. 6-11). The deposits, composed of unconsolidated clay, silt, sand, gravel, and boulders, are generally coarser in the western part of the county, near the mountains. Locally derived coarse material has been deposited in the valleys of streams that head in the central part of the basin; however, gravel derived from the Bighorn Mountains has been deposited in the eastern part of the county, in the valleys of the Powder River and Clear Creek. The greatest thickness of alluvium penetrated by a well (56-82-19ac) was 91 feet in the valley of Dutch Creek, and seismic shotholes penetrated 100 feet of alluvium in the same valley. (See fig. 16.)

\section{WATER-BEARING PROPERTIES}

The quantity of water that the flood-plain and terrace deposits will yield to wells depends on the size and sorting of the material and the 
saturated thickness of the deposits. Yields from terrace deposits are as large as $25 \mathrm{gpm}$, and those from the flood-plain deposits are as large as $108 \mathrm{gpm}$. Larger yields could probably be developed, however.

The saturated thickness of the alluvium in the Powder River valley is not sufficient to yield large supplies of water to wells. The alluvium downstream from the confluence of Powder River and Clear Creek is about 20 feet thick, and the saturated thickness is about 7 feet, as determined by test drilling (fig. 15). The material penetrated was not as coarse as that penetrated in other parts of the valley, but the thickness of the alluvium and the saturated section here is comparable to that in test holes upstream in Johnson County (Whitcomb and McCullough, oral commun., 1961). The thickness of the alluvium is also comparable to that downstream at the proposed site of the Moorehead Dam (Olive, 1957, p. 20).

The alluvium in some of the smaller valleys is thicker than that in the Powder River valley (fig. 16). Sufficient coarse material was not penetrated by test holes in the alluvium of Prairie Dog Creek to furnish moderate supplies of water to wells. Thicker deposits of coarse material are known at other locations in the valley, and moderate supplies of ground water can be developed at places from the alluvium of Prairie Dog Creek as well as from the alluvium in the valleys of the Tongue River and Dutch Creek.

\section{RECHARGE AND DISCHARGE}

The alluvium is recharged from precipitation and from irrigation water. Irrigation is a major source of recharge, and its contribution to the ground water in the alluvium is responsible for the existence of adequate supplies in some areas. Water in the terrace deposits west of Sheridan reportedly was inadequate during a year when a below-

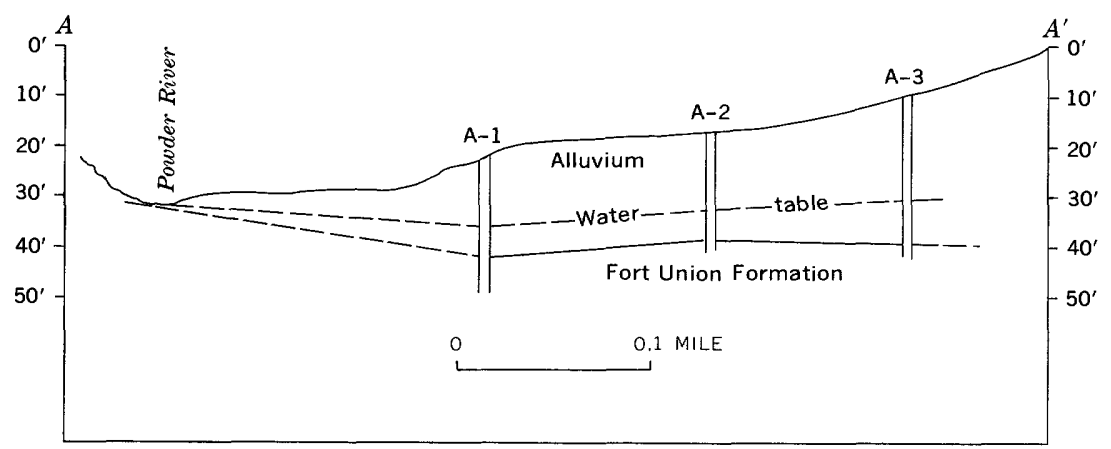

Figure 15.-Part of the Powder River valley, view downstream, 1.5 miles downstream from the confluence with Clear Creek. 

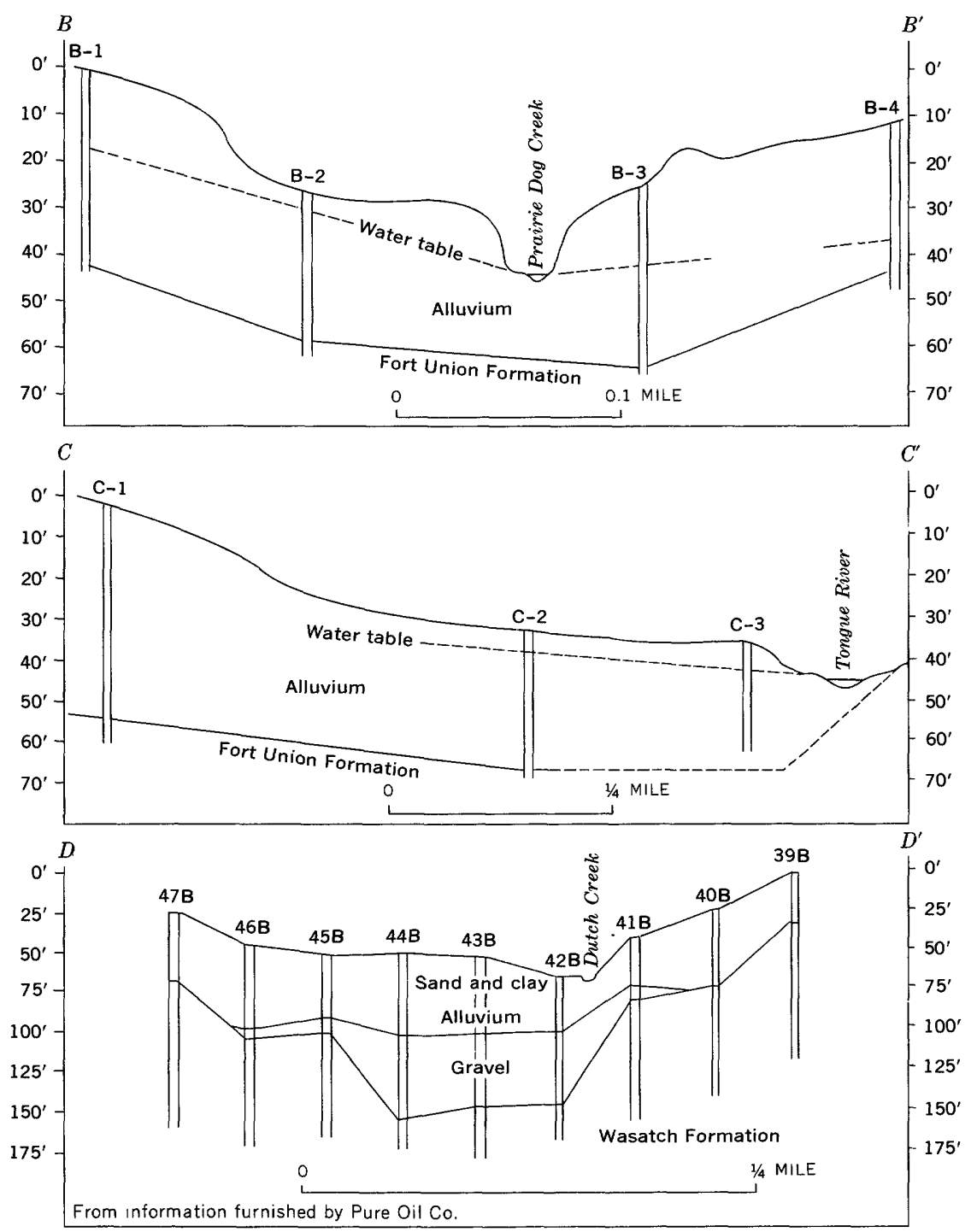

Frgure 16.-Valleys of Prairie Dog Creek $\left(B-B^{\prime}\right)$, Tongue River $\left(C-C^{\prime}\right)$, and Dutch Creek $\left(D-D^{\prime}\right)$, view downstream.

normal amount of irrigation water was applied in the surrounding area. A rancher near Ranchester reported that the terrace deposits on his ranch did not contain water until a canal was constructed to bring in water for irrigation on the terrace. Water for domestic supply, in 1960, was obtained from a spring at the edge of the terrace 
deposit near the ranch buildings. Water was applied to the lands upgradient from the spring at least once, late in the irrigation season, to insure an adequate domestic supply for the winter.

Ground water is discharged from the deposits of Quaternary age by evaporation, transpiration, wells, seeps, and springs, and by seepage to streams. The slope of the water table is toward the streams shown in figure $16\left(B-B^{\prime}, C-C^{\prime}\right)$ because of irrigation on the bordering lands, and, at least in these reaches of the streams, ground water is contributing to streamflow. Because only the land on the west side of Prairie Dog Creek was irrigated, the slope of the water table toward the stream is greater on the west side of the creek than on the east side.

\section{QUALITY OF WATER}

Chemical analyses of water from the alluvium are given in table 4 . The diverse chemical characteristics of the water are illustrated graphically in figure 14 . Iron content ranges from 0.00 to $4.3 \mathrm{ppm}$, and sulfate content, from 8.0 to $1,020 \mathrm{ppm}$. The dissolved-solids content ranges from 272 to $2,060 \mathrm{ppm}$. The water is very hard.

Water from each well sampled has some chemical characteristic that is undesirable in water for a domestic supply. As an irrigation supply, water from the alluvium has a low sodium hazard but a medium to very high salinity hazard. Supplies developed for stock use will probably be good to fair. In general, the alluvium in the mountains and along the mountain flanks yields water of better quality than that in other areas, principally because the quality of surface-water recharge is better.

\section{DEVELOPMENT}

Most wells that tap deposits of Quaternary age have been drilled in the western part of the county. The deposits of Quaternary age are more widespread in this area and generally yield water of a better quality than do those in the eastern part of the county. Only one irrigation well was in use at the time of this investigation; however, moderate to large yields can be developed in other areas under favorable conditions.

More extensive test drilling was not possible during the investigation, but several areas warrant exploration. Two such areas are the alluvium near the base of Moncreiffe Ridge and the terrace deposits in the northwestern part of T. 57 N., R. 86 W. Well 54-84-14bb, just north of Moncreiffe Ridge, was still in the alluvium at a total depth of 65 feet. Although the terrace deposits are only 19 feet thick where penetrated by well 57-86-9ab, the terrace in this vicinity is more than 1 mile wide, and the deposits are probably thicker elsewhere. 


\section{REFERENCES CITED}

Beath, O. A., and others, 1953, Poisonous plants and livestock poisoning: Wyoming Agr. Expr. Sta. Bull. 324, 94 p.

Brown, R. W., 1948, Correlation of Sentinel Butte Shale in western North Dakota : Am. Assoc. Petroleum Geologists Bull., v. 32, no. 7, p. 1265-1274.

California State Water Pollution Control Board, 1952, Water-quality criteria: California State Water Pollution Control Board Pub. 3, 512 p.

Chamberlin, R. T., 1909, Notes on explosive mine gasses and dusts: U.S. Geol. Survey Bull. 383, 67 p.

Cooper, H. H., Jr., and Jacob, C. E., 1946, A generalized graphical method for evaluating formation constants and summarizing well-field history: Am. Geophys. Union Trans., v. 27, no. 4, p. 526-534.

Darton, N. H., 1904, Comparison of the stratigraphy of the Black Hills, Bighorn Mountains, and Rocky Mountain Front Range: Geol. Soc. America Bull., v. 15 , p. 379-448.

1905, Preliminary report on the geology and underground water resources of the central Great Plains: U.S. Geol. Survey Prof. Paper 32, 433 p.

1906, Description of the Bald Mountain-Dayton quadrangle (Wyoming): U.S. Geol. Survey Geol. Atlas, Folio 141.

Eaton, F. M., 1936, Changes in the composition of ground-waters resultant to anaerobic sulfate decomposition and the attendant precipitation of calcium and magnesium: Am. Geophys. Union Trans., Ann. Mtg. 17, pt. 2, p. 512-516. 1950, Significance of carbonates in irrigation waters: Soil Sci., v. 69, no. 2, p. $123-133$.

Foster, M. D., 1950, The origin of high sodium bicarbonate waters in the Atlantic and Gulf Coastal Plain: Geochim. et Cosmochim. Acta, v. 1, p. 33-48.

Gale, H. S., and Wegemann, C. H.; 1910, The Buffalo coal field, Wyoming in Coal fields in Wyoming: U.S. Geol. Survey Bull. 381-B, p. 137-169.

Hazen, Allen, 1892, A new color standard for natural waters: Am. Chem. Soc. Jour., v. 12, p. $427,428$.

Hem. J. D., 1959, Study and interpretation of chemical characteristics of natural water: U.S. Geol. Survey Water-Supply Paper 1473, 269 p.

Hendricks, E. L., 1961, Surface Water Supply of the United States, 1960, Part 6-A : U.S. Geol. Survey Water-Supply Paper 1709, 477 p.

Leopold, L. B., and Miller, J. P., 1954, A postglacial chronology for some alluvial valleys in Wyoming: U.S. Geol. Survey Water-Supply Paper 1261, 90 p.

Lewis, J. V., 1934, The evolution of the mineral coals: Econ. Geology, v. 29, no. 1, p. 1-38.

Love, J. D., and others, 1955, Geologic map of Wyoming: U.S. Geol. Survey Map.

Mapel, W. J., 1959, Geology and coal resources of the Buffalo-Lake De Smet area, Johnson and Sheridan Counties, Wyoming: U.S. Geol. Survey Bull. 1078, $148 \mathrm{p}$.

Meinzer, O. E., 1923, Outline of ground-water hydrology: U.S. Geol. Survey Water-Supply Paper 494, $71 \mathrm{p}$.

1942, Occurrence, origin, and discharge of ground water, in Hydrology : New York, Dover Pubs., p. 385-443.

Moore, E. S., 1950, Coal: New York, John Wiley \& Sons, $473 \mathrm{p}$.

Moore, E. W., 1940, Progress report of the committee on quality tolerances of water for industrial uses: New England Water Works Assoc. Jour., v. 54, p. 271. 
Olive, W. W., 1957, The Spotted Horse coalfield, Sheridan and Campbell Counties, Wyoming: U.S. Geol. Survey Bull. $1050,83 \mathrm{p}$.

Osterwald, F. W., 1959, Structure and Petrology of the northern Big Horn Mountains, Wyoming: Wyoming Geol. Survey Bull. 48, 47 p.

Richards, P. W., and Nieschmidt, C. L., 1961, The Bighorn Dolomite and correlative formations in southern Montana and northern Wyoming: U.S. Geol. Survey Oil and Gas Inv. Map OM-202.

Riffenburg, H. B., 1925, Chemical character of ground water of the northern Great Plains: U.S. Geol. Survey Water-Supply Paper 560-B, p. 31-52.

Sharp, R. P., 1948, Early Tertiary fanglomerate, Bighorn Mountains, Wyoming: Jour. Geol., v. 56, p. 1-15.

Taff, J. A., 1909, The Sheridan coal field, Wyoming, in coal fields in Wyoming: U.S. Geol. Survey Bull. 341-B, p. 123-150.

Theis, C. V., 1935, The relation between the lowering of the piezometric surface and the rate and duration of discharge of a well using ground-water storage: Am. Geophys. Union Trans., Ann. Mtg. 16, pt. 2, p. 519-524.

Thorp, James, and others, 1939, Soil Survey of Sheridan County, Wyoming: U.S. Dept. Agriculture Bur. Chemistry and Soils, 48 p.

U.S. Public Health Service, 1962, Drinking Water Standards: Public Health Service Pub. 956, $61 \mathrm{p}$.

U.S. Salinity Laboratory Staff, 1954, Diagnosis and improvement of saline and alkali soils : U.S. Dept. Agriculture Handb. 60, 160 p.

Warner, D. A., 1946, Geology and ground-water resources of the Ranchester area, Wyoming: U.S. Geol. Survey open-file report, $11 \mathrm{p}$.

Zapp, A. D., 1953, Structure contour map of the Powder River Basin, Wyoming and Montana: U.S. Geol. Survey Oil and Gas Inv. Map OM-133. 

BASIC DATA 


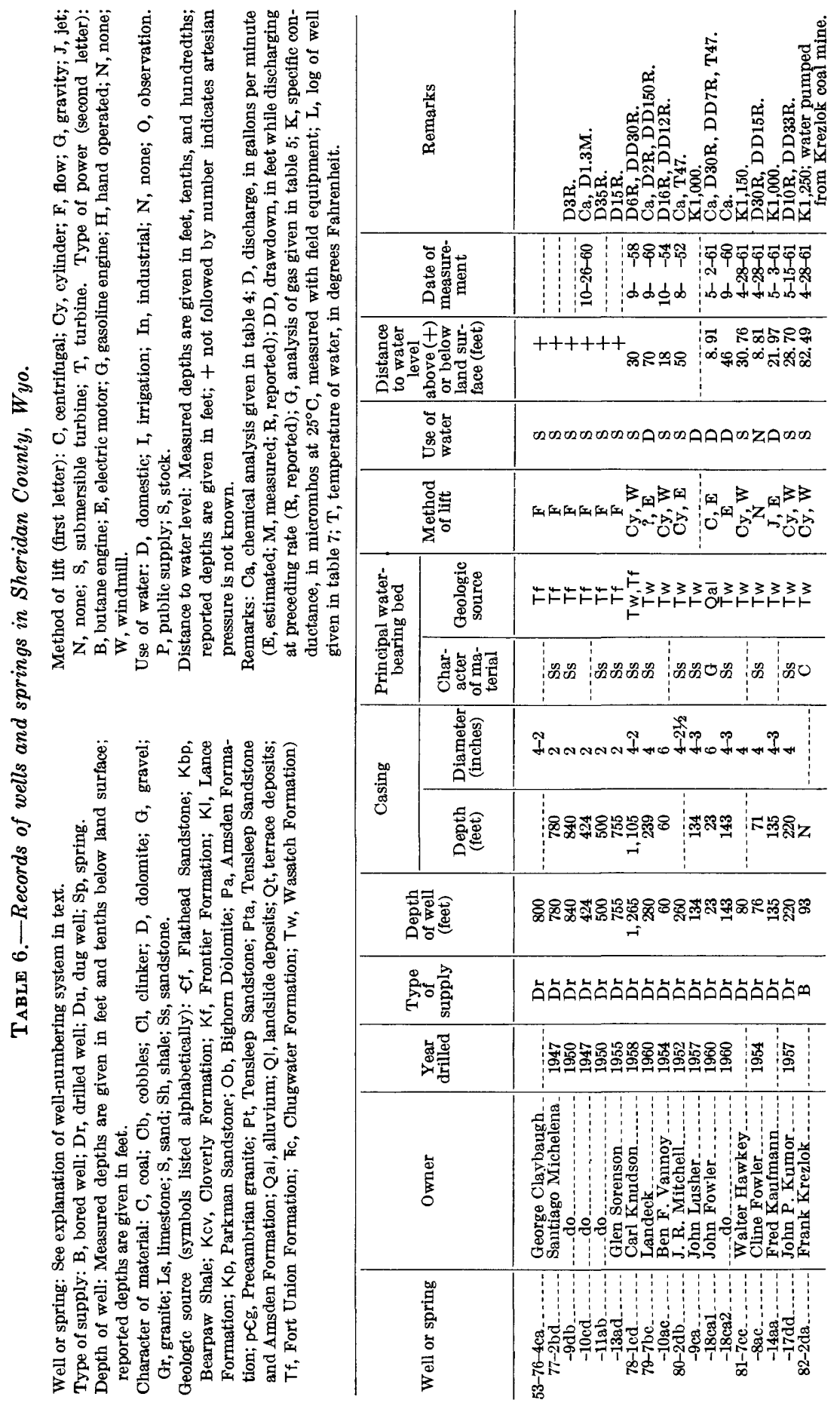




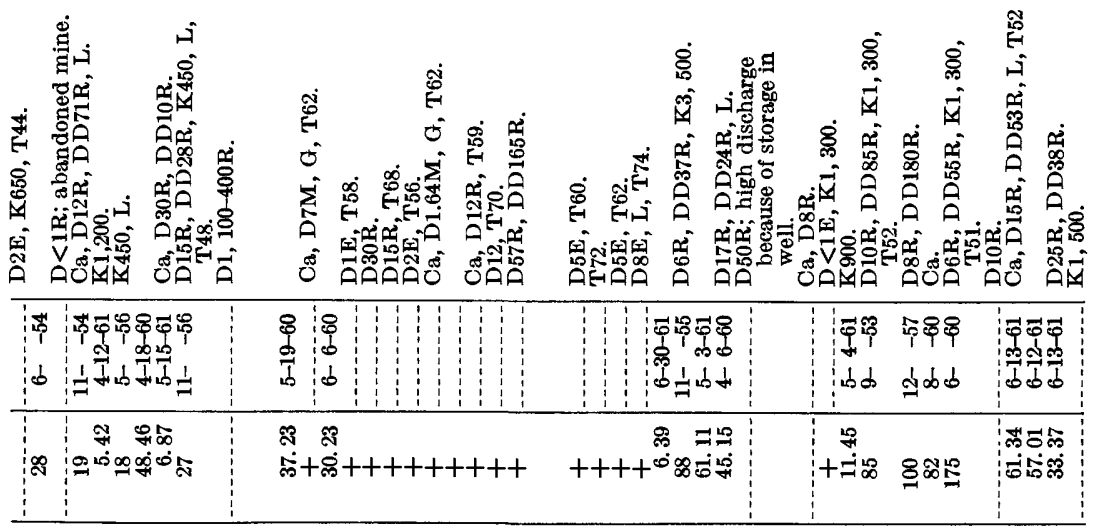

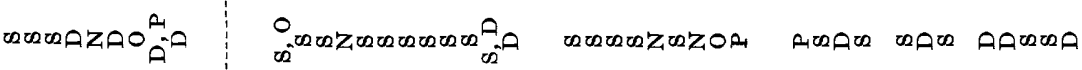

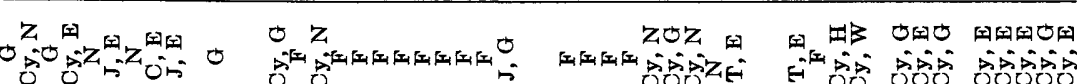

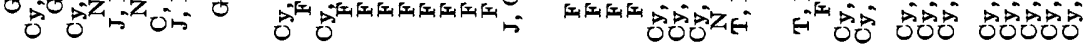

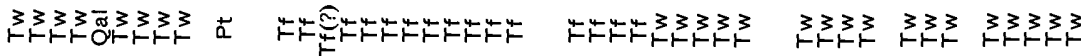

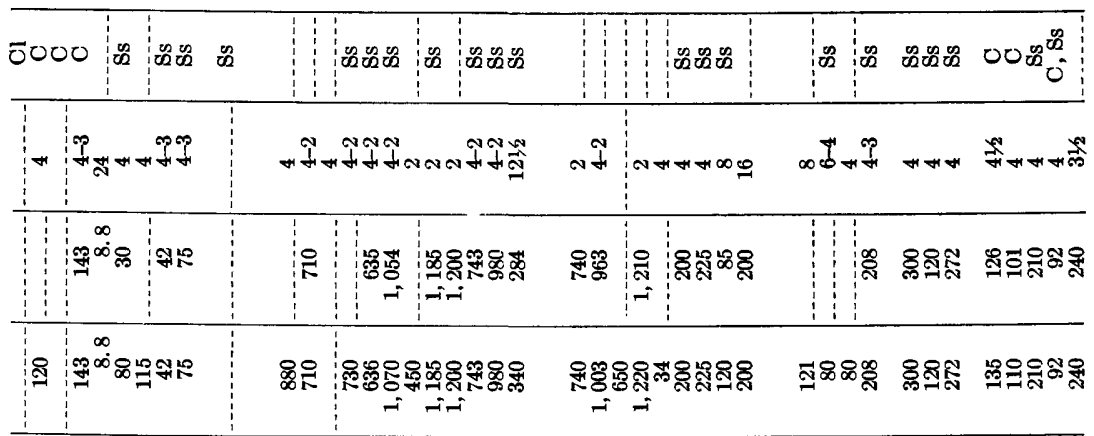

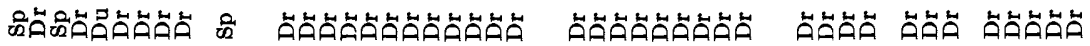

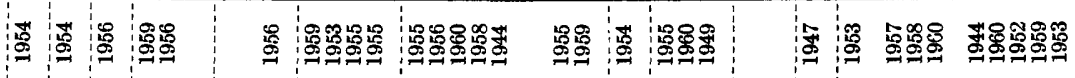

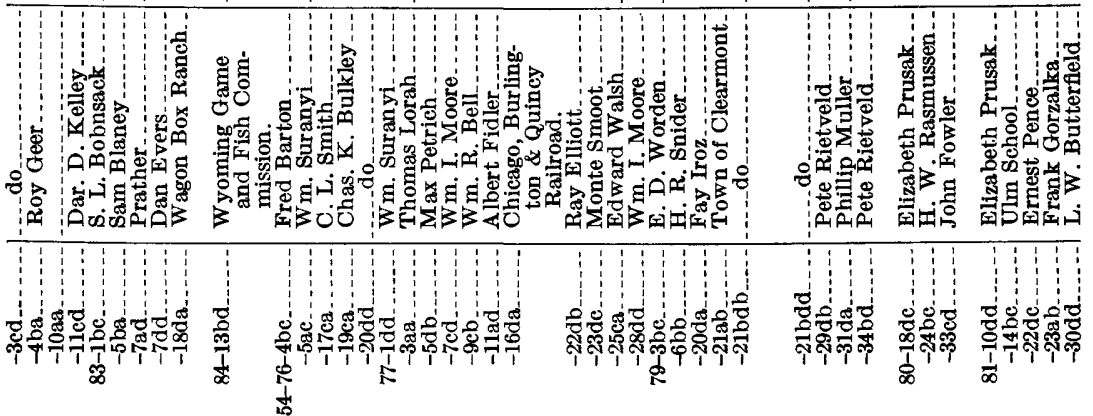




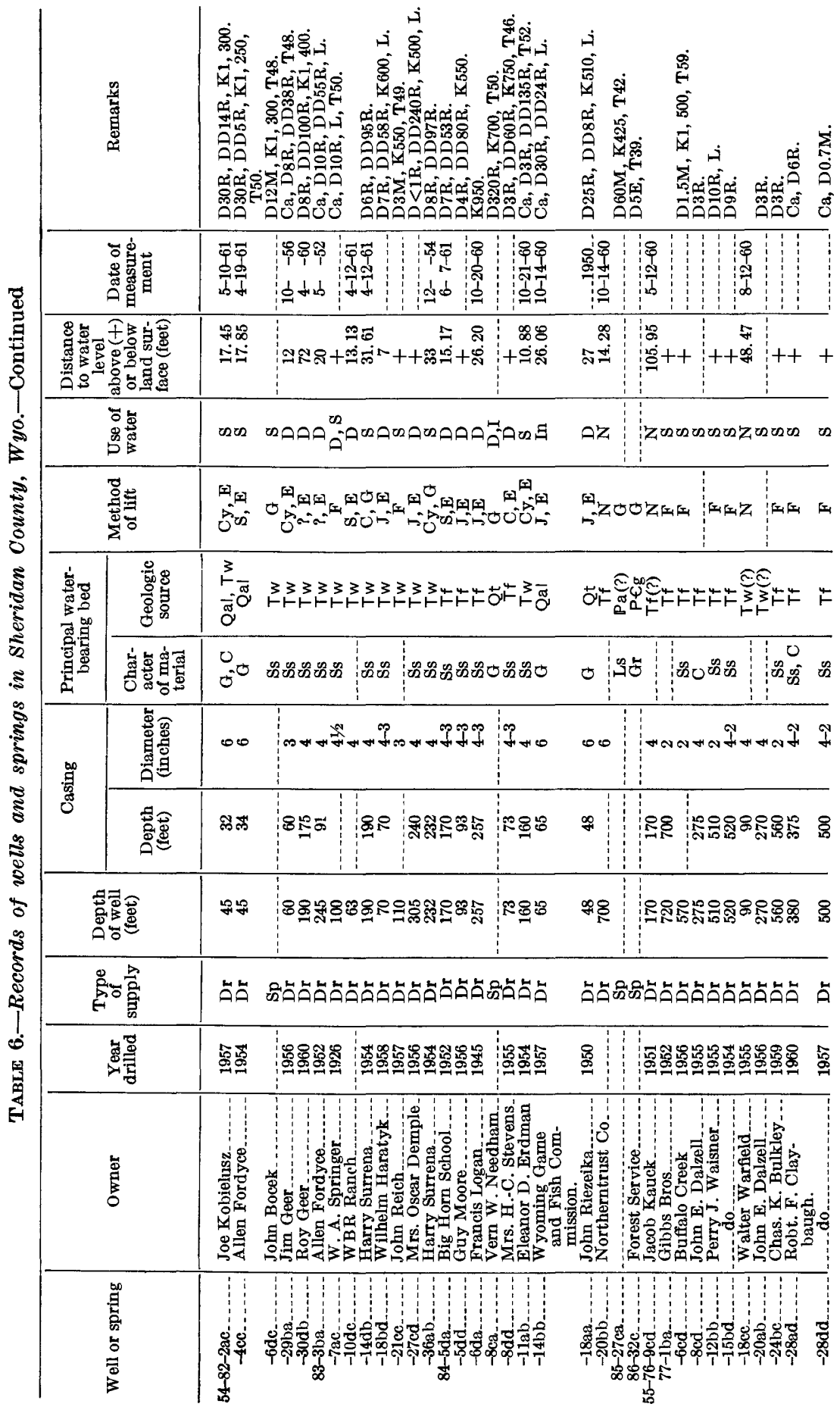



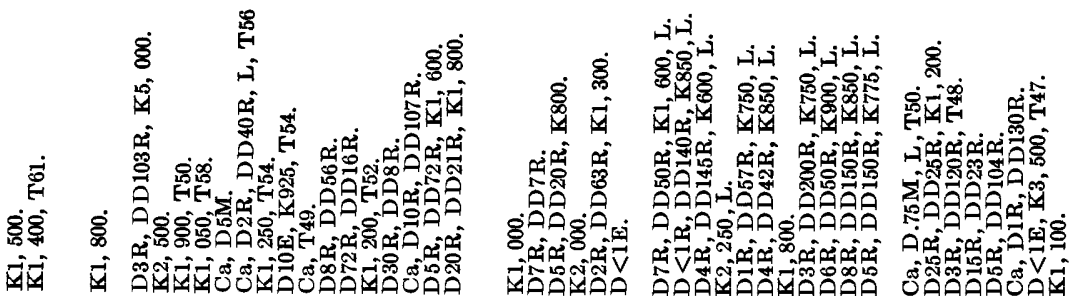

\begin{tabular}{|c|c|c|c|c|c|c|}
\hline 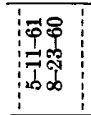 & 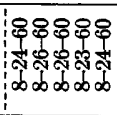 & \begin{tabular}{l}
5 \\
1 \\
1 \\
\hdashline
\end{tabular} & 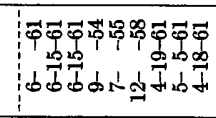 & 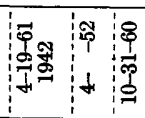 & 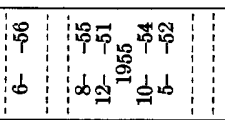 & 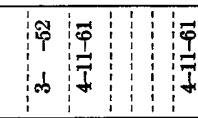 \\
\hline 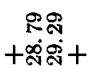 & 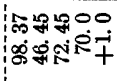 & + & 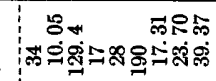 & : & $\theta++\infty \infty$ & 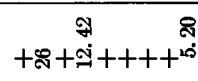 \\
\hline
\end{tabular}

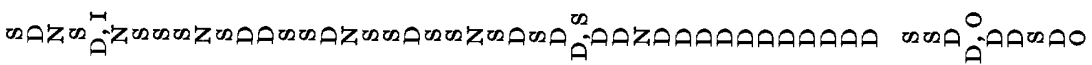

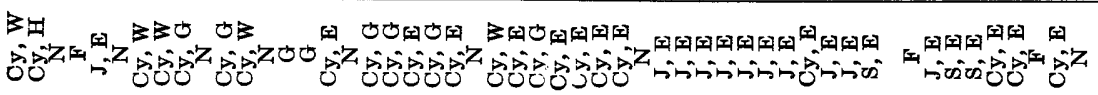

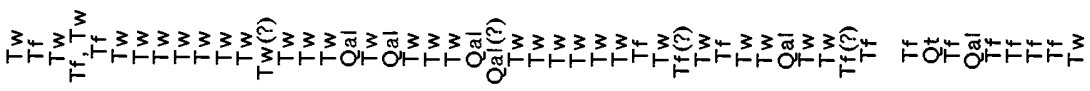

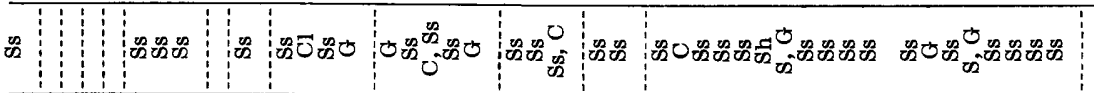

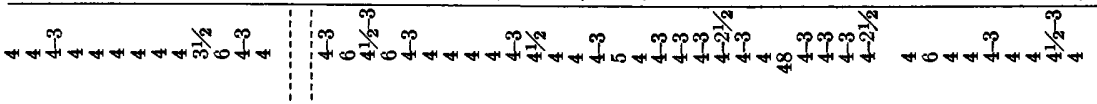

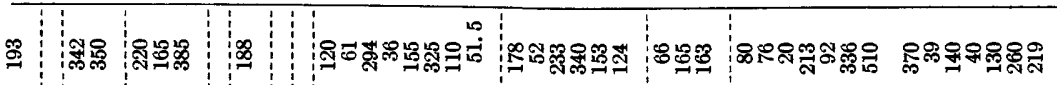

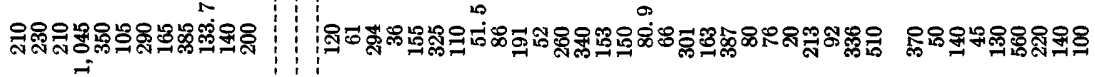

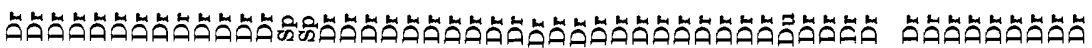

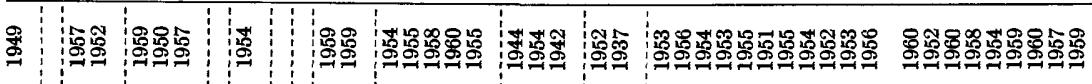

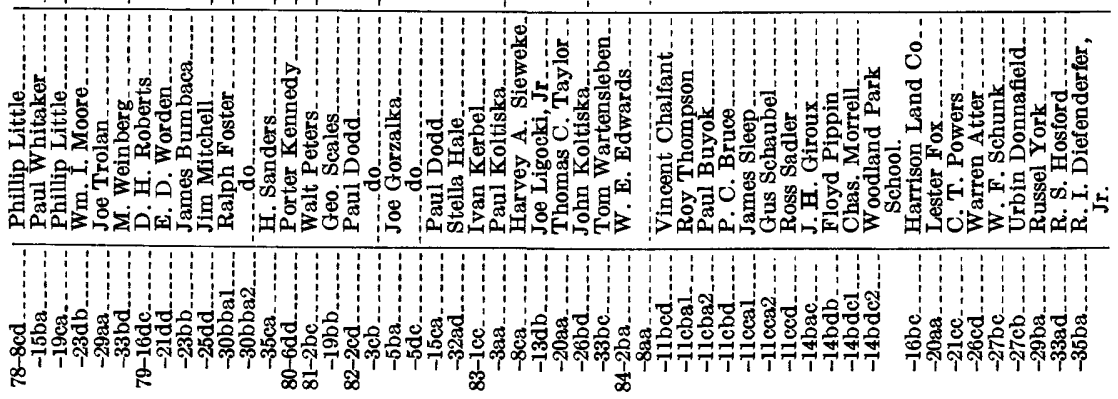




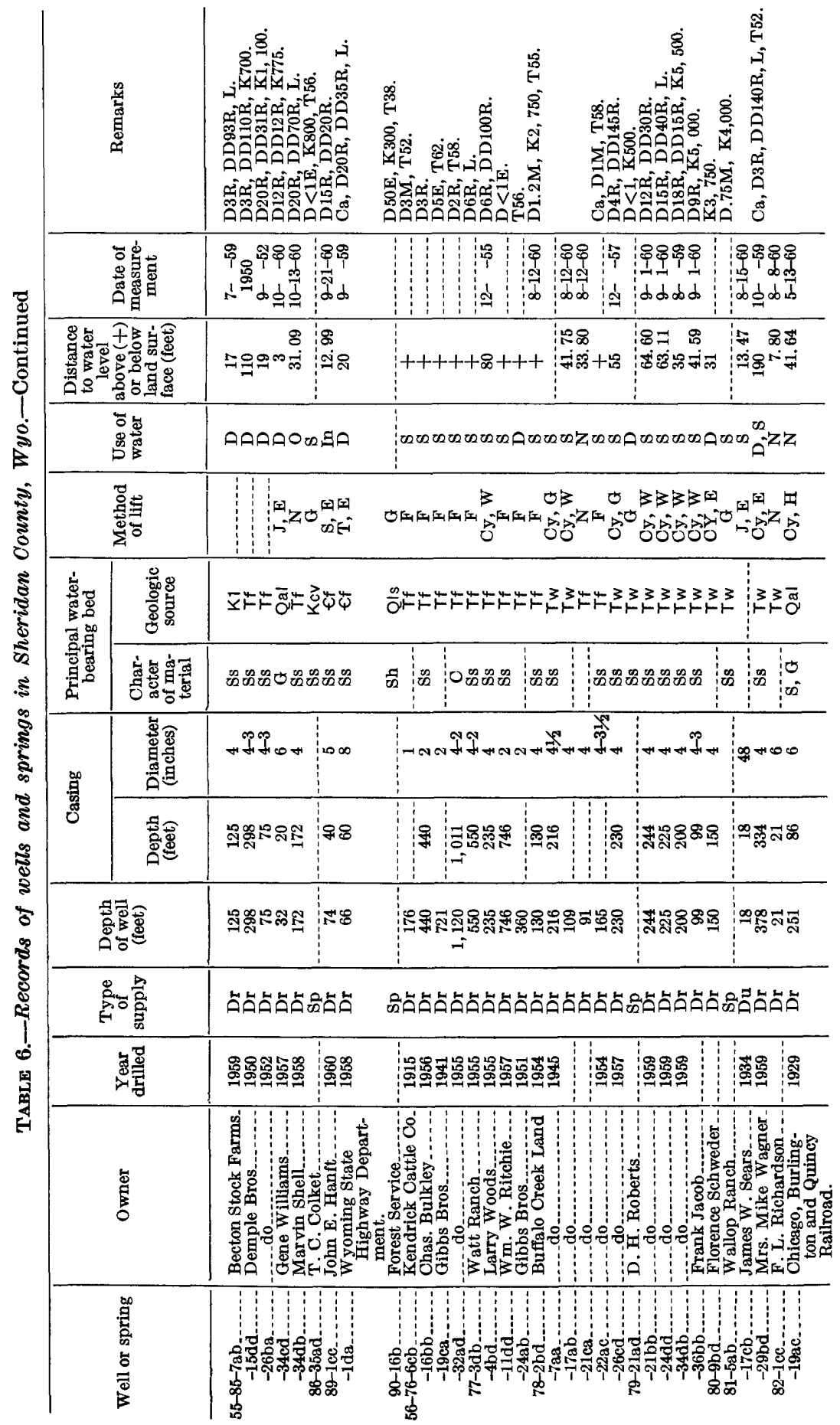




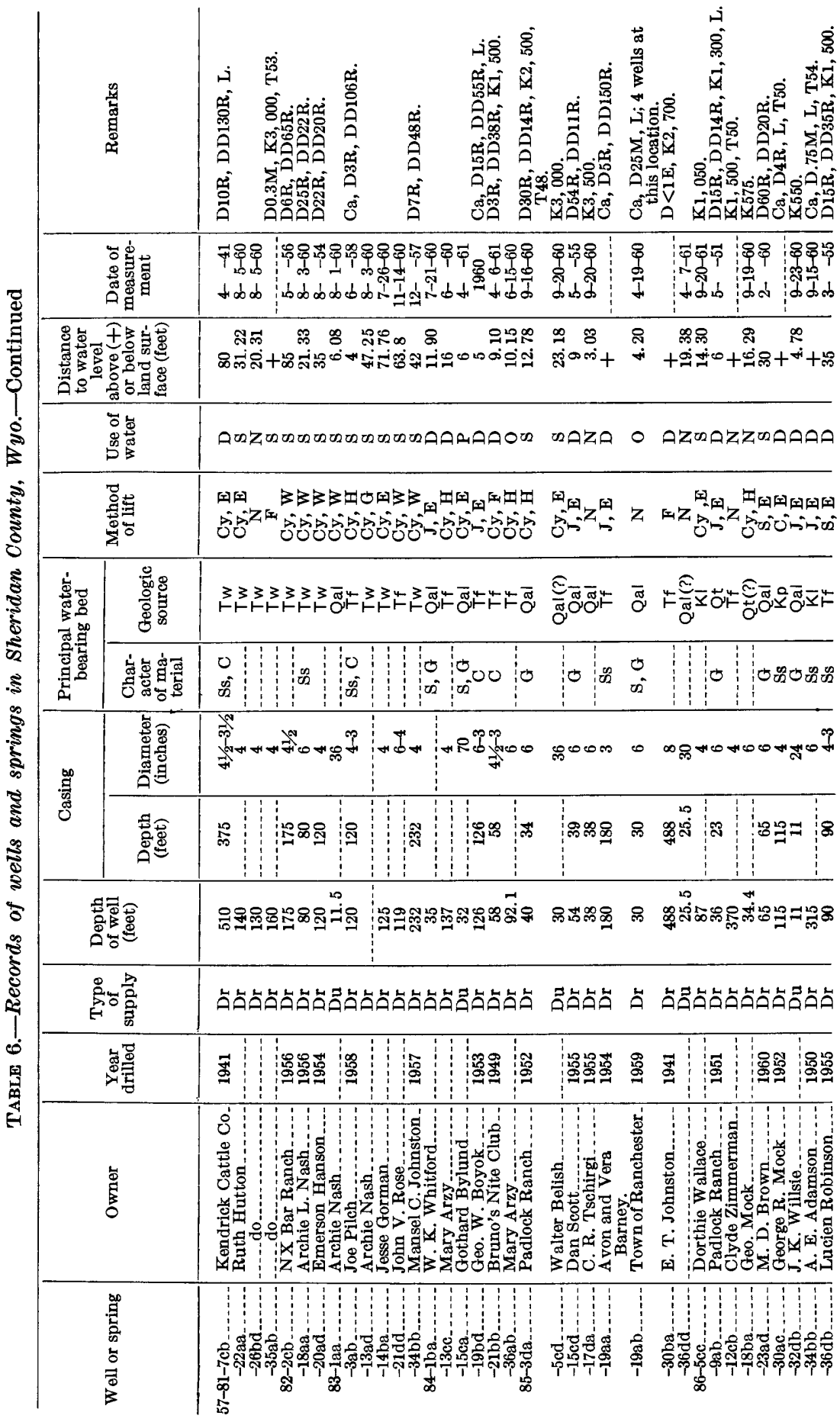




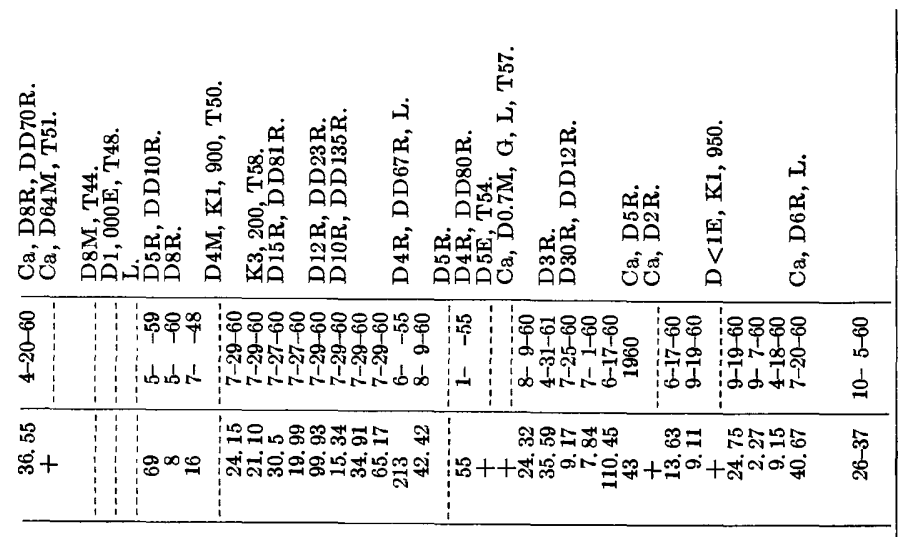

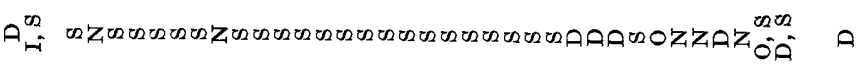

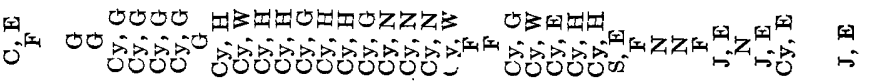

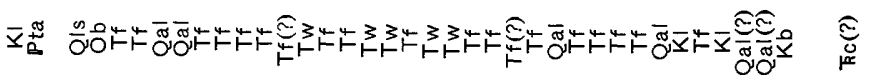

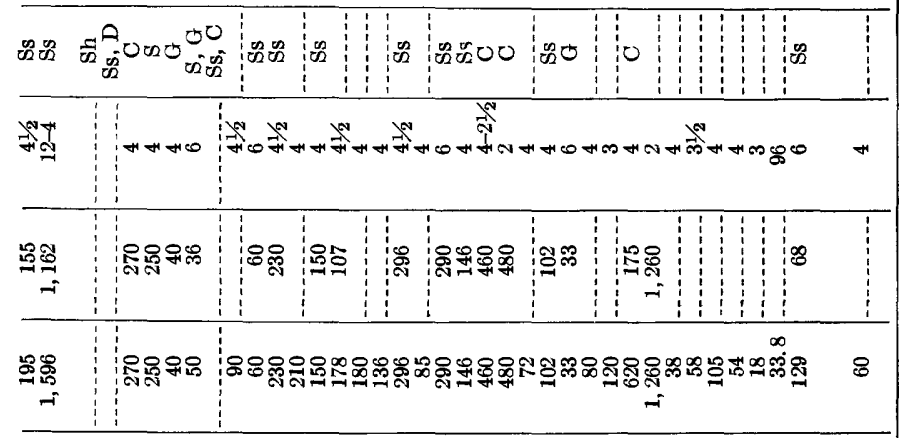

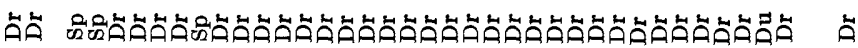

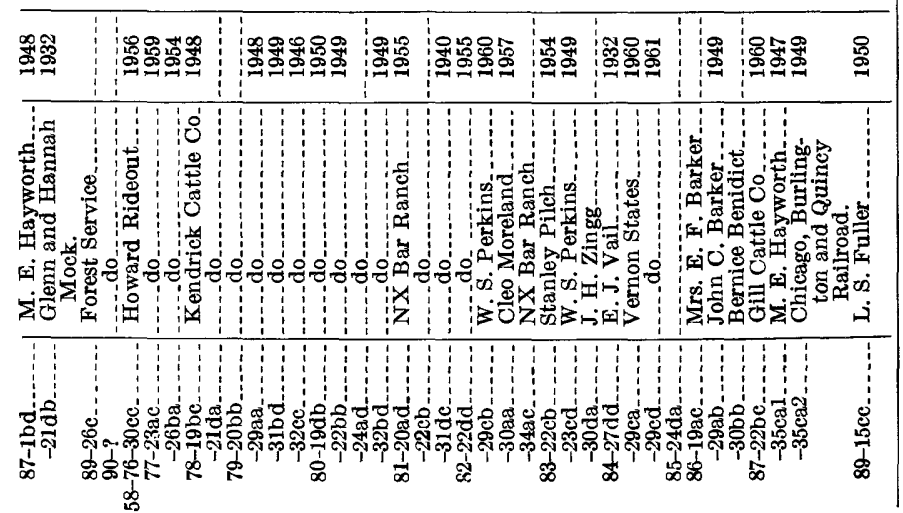


TaBLE 7.-Logs of test holes, seismic shotholes, and wells

[Listed in this table are sample logs of test holes, drillers' logs of seismic shotholes, and logs of selected water wells. The drillers' logs were obtained from drillers' records and are essentially unchanged]

SAMPLE LOGS

\begin{tabular}{|c|c|c|}
\hline Material & $\begin{array}{l}\text { Thick- } \\
\text { ness } \\
\text { (ft) }\end{array}$ & 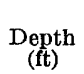 \\
\hline
\end{tabular}

Alluvium:

Silt, brown, and some very fine sand

Sand, brown, very fine to medium, silt and some coarse sand, and a few granules.....

Sand, brown, fine to coarse, silt and very fine sand, and some gravel...

Sand, brown, fine to coarse, and silt and very fine sand.

Fort Union Formation:

Sand, bluish-gray, very fine.........

Test hole A-2, section $A-A^{\prime}$
Alluvium:

Silt, brown _...... 10

Silt, brown, and very fine sand -... $\quad 5$

$\begin{array}{ll}0 & 10\end{array}$

Silt, brown; some very fine to fine sand -

Fort Union Formation:

Shale, bluish-gray.-.-

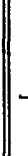

\section{Alluvium-Continued}

Silt, brown ..........

Silt, brown and dark-brown, and some very fine to fine sand ........

Thick-

ness Depth

Test hole B-1, section $B-B^{\prime}-$ Continued

Fort Union Formation:

Sand, bluish-gray, very fine to fine... -

Test hole B-2, section $B-B^{\prime}$

Alluvium:

Silt, brown ..........

Silt, brown; some very fine to coarse sand .............

Sand, brown, very fine to fine, silt, and a few granules.

Sand, very fine to fine, and some medium to coarse sand and silt.......

Sand, very fine to medium, and silt..

Shale, gray, and fine to coarse gravel

No returns, driller's log shows gravel streaks to $35 \mathrm{ft}$

Test hole $A-3$, section $A-A^{\prime}$

Fort Union Formation:

Shale, bluish-gray -..-

6

\section{Alluvium:}

Silt, brown .........

Clay, brown, silty - -

Sand, very fine, and

520
silt. . . .........

Fort Union Formation:

Shale, bluish-gray, silty

Test hole B-1, section $B-B^{\prime}$

Alluvium:

Silt, brown, and some very fine to fine sand.
Test hole B-3, section $B-B^{\prime}$

Alluvium:

Silt, brown _........

Silt, brown; some medium to coarse sand and granules.-

Silt, brown, and some very fine to medium sand....

Silt, brown, and fine sand to fine

Fort Union Formation:

Coal _.... 6 
TABLE 7.-Logs of test holes, seismic shotholes, and wells-Continued

SAMPLE LOGS-Continued

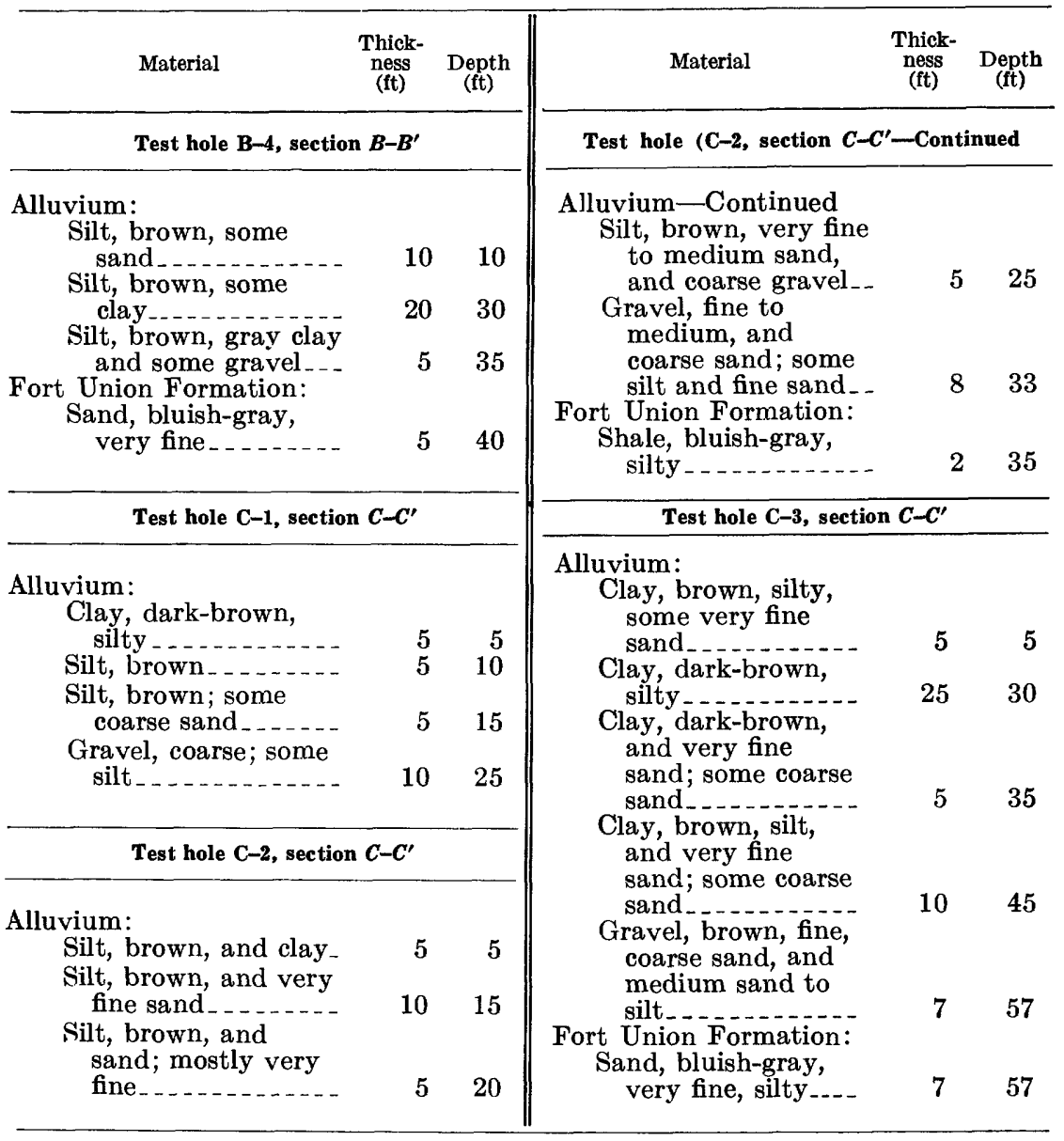

DRILLERS' LOGS

\begin{tabular}{|c|c|c|c|c|}
\hline \multicolumn{2}{|c|}{ Seismic shothole $39-B$, section $D-D^{\prime}$} & \multicolumn{3}{|c|}{ Seismic shothole $42-B$, section $D-D^{\prime}$} \\
\hline $\begin{array}{l}\text { Sand } \\
\text { Shale, blue. }\end{array}$ & $\begin{array}{r}30 \\
110\end{array}$ & $\begin{array}{l}\text { Sand } \\
\text { Gravel, red clinker. } \\
\text { Shale, blue. }\end{array}$ & $\begin{array}{l}35 \\
43 \\
22\end{array}$ & $\begin{array}{r}35 \\
78 \\
100\end{array}$ \\
\hline \multicolumn{2}{|c|}{ Seismic shothole $40-B$, section $D-D^{\prime}$} & \multicolumn{3}{|c|}{ Seismic shothole 43-B, section $D-D^{\prime}$} \\
\hline $\begin{array}{l}\text { Sand } \\
\text { Shale, blue }\end{array}$ & $\begin{array}{r}45 \\
110\end{array}$ & $\begin{array}{l}\text { Sand and clay } \\
\text { Gravel, red clinker. } \\
\text { Shale, blue }\end{array}$ & $\begin{array}{l}45 \\
45 \\
30\end{array}$ & $\begin{array}{r}45 \\
90 \\
120\end{array}$ \\
\hline \multicolumn{2}{|c|}{ Seismic shothole 41-B, section $D-D^{\prime}$} & \multicolumn{3}{|c|}{ Seismic shothole 44-B, section $D-D^{\prime}$} \\
\hline $\begin{array}{l}\text { Clay } \\
\text { Gravel, red clinker. } \\
\text { Shale, blue. }\end{array}$ & $\begin{array}{r}30 \\
38 \\
110\end{array}$ & $\begin{array}{l}\text { Clay, yellow and blue } \\
\text { Gravel, red clinker } \\
\text { Shale, blue. }\end{array}$ & $\begin{array}{l}50 \\
50 \\
20\end{array}$ & $\begin{array}{r}50 \\
100 \\
120\end{array}$ \\
\hline
\end{tabular}


TABLE 7.-Logs of test holes, seismic shotholes, and wells-Continued

DRILLERS' LOGS-Continued

\begin{tabular}{|c|c|c|}
\hline Material & $\begin{array}{l}\text { Thick- } \\
\text { ness } \\
(\mathrm{ft})\end{array}$ & $\underset{\text { (ft) }}{\text { Depth }}$ \\
\hline \multicolumn{3}{|c|}{ Seismic shothole $45-B$, section $D-D^{\prime}$} \\
\hline $\begin{array}{l}\text { Clay } \\
\text { Gravel, red clinker } \\
\text { Shale, blue }\end{array}$ & $\begin{array}{r}38 \\
9 \\
73\end{array}$ & $\begin{array}{r}38 \\
47 \\
120\end{array}$ \\
\hline \multicolumn{3}{|c|}{ Seismic shothole 46-B, section $D-D^{\prime}$} \\
\hline $\begin{array}{l}\text { Clay, yellow } \\
\text { Gravel, red clinker. } \\
\text { Shale, blue and gray }\end{array}$ & $\begin{array}{r}50 \\
5 \\
65\end{array}$ & $\begin{array}{r}50 \\
55 \\
120\end{array}$ \\
\hline Seismic shothole 47-B, s & $\operatorname{tion} D-$ & \\
\hline $\begin{array}{l}\text { Sand and clay } \\
\text { Clay, blue }\end{array}$ & $\begin{array}{l}40 \\
90\end{array}$ & $\begin{array}{r}40 \\
130\end{array}$ \\
\hline \multicolumn{3}{|c|}{ Well 53-82-11ed } \\
\hline $\begin{array}{l}\text { Clay } \\
\text { Gravel } \\
\text { Shale, blue. } \\
\text { Sand, } \\
\text { Shale, blue. } \\
\text { Sand, hard water } \\
\text { Shale, blue } \\
\text { Coal, water-bearing } \\
\text { Shale, dark }\end{array}$ & $\begin{array}{r}8 \\
14 \\
4 \\
6 \\
34 \\
8 \\
41 \\
24 \\
4\end{array}$ & $\begin{array}{r}8 \\
22 \\
26 \\
32 \\
66 \\
74 \\
115 \\
139 \\
143\end{array}$ \\
\hline
\end{tabular}

\begin{tabular}{|c|c|c|}
\hline \multicolumn{3}{|c|}{ Well 53-83-5ba } \\
\hline Sand. - & 10 & 10 \\
\hline Gravel and cobbles. & 10 & 20 \\
\hline Sandstone & 55 & 75 \\
\hline Shale, blue............ & 5 & 80 \\
\hline
\end{tabular}

\begin{tabular}{|c|c|c|}
\hline \multicolumn{3}{|c|}{ Well 53-83-18da } \\
\hline $\begin{array}{l}\text { Gravel and cobbles } \\
\text { Sandstone }\end{array}$ & $\begin{array}{l}20 \\
55\end{array}$ & $\begin{array}{l}20 \\
75\end{array}$ \\
\hline
\end{tabular}

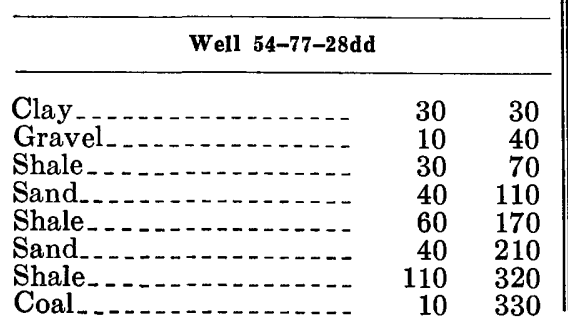

\begin{tabular}{|c|c|c|}
\hline Material & $\begin{array}{c}\text { Thick- } \\
\text { ness } \\
\text { (ft) }\end{array}$ & $\underset{\text { (ft) }}{\text { Depth }}$ \\
\hline \multicolumn{3}{|c|}{ Well 54-77-28dd-Continued } \\
\hline $\begin{array}{l}\text { Shale } \\
\text { Sand } \\
\text { Shale } \\
\text { Coal } \\
\text { Shale } \\
\text { Sand } \\
\text { Shale } \\
\text { Sand } \\
\text { Shale } \\
\text { Coal } \\
\text { Shale } \\
\text { Sand } \\
\text { Shale } \\
\text { Coal } \\
\text { Shale } \\
\text { Sand } \\
\text { Shale } \\
\text { Coal. } \\
\text { Shale } \\
\text { Sand. }\end{array}$ & $\begin{array}{r}50 \\
40 \\
20 \\
20 \\
80 \\
40 \\
80 \\
60 \\
20 \\
30 \\
50 \\
20 \\
20 \\
20 \\
80 \\
20 \\
100 \\
10 \\
70 \\
60\end{array}$ & $\begin{array}{r}380 \\
420 \\
440 \\
460 \\
540 \\
580 \\
660 \\
720 \\
740 \\
770 \\
820 \\
840 \\
860 \\
880 \\
960 \\
980 \\
1,080 \\
1,090 \\
1,160 \\
1,220\end{array}$ \\
\hline \multicolumn{3}{|l|}{ Well 54-79-21ab } \\
\hline $\begin{array}{l}\text { Soil. } \\
\text { Gravel, red clinker } \\
\text { Sand, blue. } \\
\text { Shale, blue. } \\
\text { Coal_, } \\
\text { Shale, blue, with sand } \\
\quad \text { streaks } \\
\text { Sand, water-bearing. } \\
\text { Shale, blue... }\end{array}$ & $\begin{array}{r}5 \\
20 \\
7 \\
23 \\
2 \\
27 \\
16 \\
20\end{array}$ & $\begin{array}{r}5 \\
25 \\
32 \\
55 \\
57\end{array}$ \\
\hline \multicolumn{3}{|l|}{ Well 54-81-14bc } \\
\hline $\begin{array}{l}\text { Clay } \\
\text { Shale, blue } \\
\text { Sand, } \\
\text { Shale, blue and dark } \\
\text { Coal, water. }\end{array}$ & $\begin{array}{r}22 \\
19 \\
4 \\
57 \\
8\end{array}$ & $\begin{array}{r}22 \\
41 \\
45 \\
102 \\
110\end{array}$ \\
\hline
\end{tabular}

Well 54-83-3ba

Clay

Sandstone $\ldots . \ldots 250$

Shale, blue.......... $14 \quad 94$

Sand, water-bearing -..- 399

Shale, blue

Sand, water........... 6140

Shale, blue

Coal, gas _......... $50 \quad 232$

Shale, blue......... $13 \quad 245$ 
TABLE 7.-Logs of test holes, seismic shotholes, and wells-Continued DRILLERS' LOGS-Continued

\begin{tabular}{|c|c|c|c|c|c|}
\hline Material & $\begin{array}{l}\text { Thick- } \\
\text { ness } \\
\text { (ft) }\end{array}$ & $\begin{array}{l}\text { Depth } \\
\text { (ft) }\end{array}$ & Material & $\begin{array}{l}\text { Thick- } \\
\text { ness } \\
\text { (ft) }\end{array}$ & $\begin{array}{c}\text { Depth } \\
\text { (ft) }\end{array}$ \\
\hline \multicolumn{3}{|l|}{ Well 54-83-7ac } & \multicolumn{3}{|c|}{ Well 55-77-12bb-Continued } \\
\hline Clay ....... & 3 & 3 & Shale ... & 110 & 118 \\
\hline Sand and gravel & 12 & 15 & Sand.... & 12 & 130 \\
\hline Shale, blue........... & 28 & 43 & Shale... & 65 & 195 \\
\hline Sandstone. - & 8 & 51 & Coal _..... & 24 & 219 \\
\hline Shale, blue.... & 35 & 86 & Shale..... & 11 & 230 \\
\hline Sand, water-bearing & 14 & 100 & Sand.-.-- & $\begin{array}{l}33 \\
12\end{array}$ & $\begin{array}{l}263 \\
275\end{array}$ \\
\hline \multicolumn{3}{|l|}{ Well 54-83-18bd } & Sand. & $\begin{array}{r}7 \\
23\end{array}$ & $\begin{array}{l}282 \\
305\end{array}$ \\
\hline Gravel _. _. & 9 & 9 & Shale & 16 & $\begin{array}{l}322 \\
338\end{array}$ \\
\hline Sandstone & 12 & 21 & Sand & 22 & 360 \\
\hline Shale, blue.. & 19 & 40 & Shale_. & $\overline{17}$ & 377 \\
\hline Sandstone _. & 2 & 42 & Coal_ & 7 & 384 \\
\hline Shale, blue.. & 7 & 49 & Shale. & 31 & 415 \\
\hline Sandstone . . . . _ & 21 & 70 & Coal _.......... & $\begin{array}{l}3 \\
8\end{array}$ & $\begin{array}{l}418 \\
426\end{array}$ \\
\hline \multicolumn{3}{|c|}{ Well 54-83-27ed } & & 82 & 508 \\
\hline Clay. & 8 & 8 & \multicolumn{3}{|l|}{ Shale $\ldots \ldots$} \\
\hline Gravel. & 6 & 14 & \multicolumn{3}{|l|}{ Well 55-79-30bba2 } \\
\hline Sandstone. & $\begin{array}{r}5 \\
16\end{array}$ & $\begin{array}{l}19 \\
35\end{array}$ & & & 17 \\
\hline Shale, blue & 37 & 72 & Shale, blue................ & 28 & 45 \\
\hline Sandstone & 11 & 83 & Sand, water.......... & 3 & 48 \\
\hline Shale, blue & 52 & 135 & Shale, blue and dark $\ldots$ & 22 & 70 \\
\hline Sandstone . . . . & 11 & 146 & Coal $\ldots \ldots$ & 5 & 75 \\
\hline$\ldots \ldots \ldots$ & 62 & 208 & Shale, blue............... & 20 & 95 \\
\hline Sandstone & 7 & 215 & Sand, water & 15 & 110 \\
\hline Shale, blue & 23 & 238 & Shale, blue & 38 & 148 \\
\hline Sandstone, water- & & & Coal & 14 & 162 \\
\hline bearing & 7 & 245 & Shale, blue and dark & 21 & 189 \\
\hline Shale, blue & 4 & 249 & Sand, soft water $\ldots \ldots$ & 6 & 195 \\
\hline $\begin{array}{l}\text { Sandstone, water- } \\
\text { bearing }\end{array}$ & 56 & 305 & Shale, blue & 5 & 200 \\
\hline \multicolumn{3}{|c|}{ Well 54-84-14bb } & \multicolumn{3}{|l|}{ Well 55-84-11bed } \\
\hline Sand & 44 & 44 & \multirow{3}{*}{$\begin{array}{l}\text { Clay } \\
\text { Gravel } \\
\text { Shale, blue- } \\
\text { Sand, water-bearing }\end{array}$} & $\begin{array}{l}10 \\
10\end{array}$ & $\begin{array}{l}10 \\
20\end{array}$ \\
\hline Sand and gravel $\ldots \ldots$ & 21 & 65 & & 24 & 44 \\
\hline \multicolumn{3}{|c|}{ Well 54-84-18aa } & & & \\
\hline \multirow{4}{*}{$\begin{array}{l}\text { Soil } \\
\text { Gravel } \\
\text { Clay, brown } \\
\text { Gravel, water } \\
\text { Sand. }\end{array}$} & \multirow{4}{*}{$\begin{array}{r}3 \\
22 \\
10 \\
10 \\
3\end{array}$} & \multirow{4}{*}{$\begin{array}{r}3 \\
25 \\
35 \\
45 \\
48\end{array}$} & \multicolumn{3}{|c|}{ Well 55-84-11cba1 } \\
\hline & & & Clay $\ldots \ldots \ldots$ & & 8 \\
\hline & & & Clay, sandy & 8 & 16 \\
\hline & & & Gravel & 8 & 24 \\
\hline \multirow{2}{*}{\multicolumn{3}{|c|}{ Well 55-77-12bb }} & Sand & 3 & 68 \\
\hline & & & Shale, blue and dark ... & 79 & .147 \\
\hline 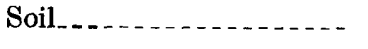 & 8 & 8 & Shale, blue and dark & 146 & 301 \\
\hline
\end{tabular}


TABLE 7.-Logs of test holes, seismic shotholes, and wells-Continued DRILLERS' LOGS-Continued

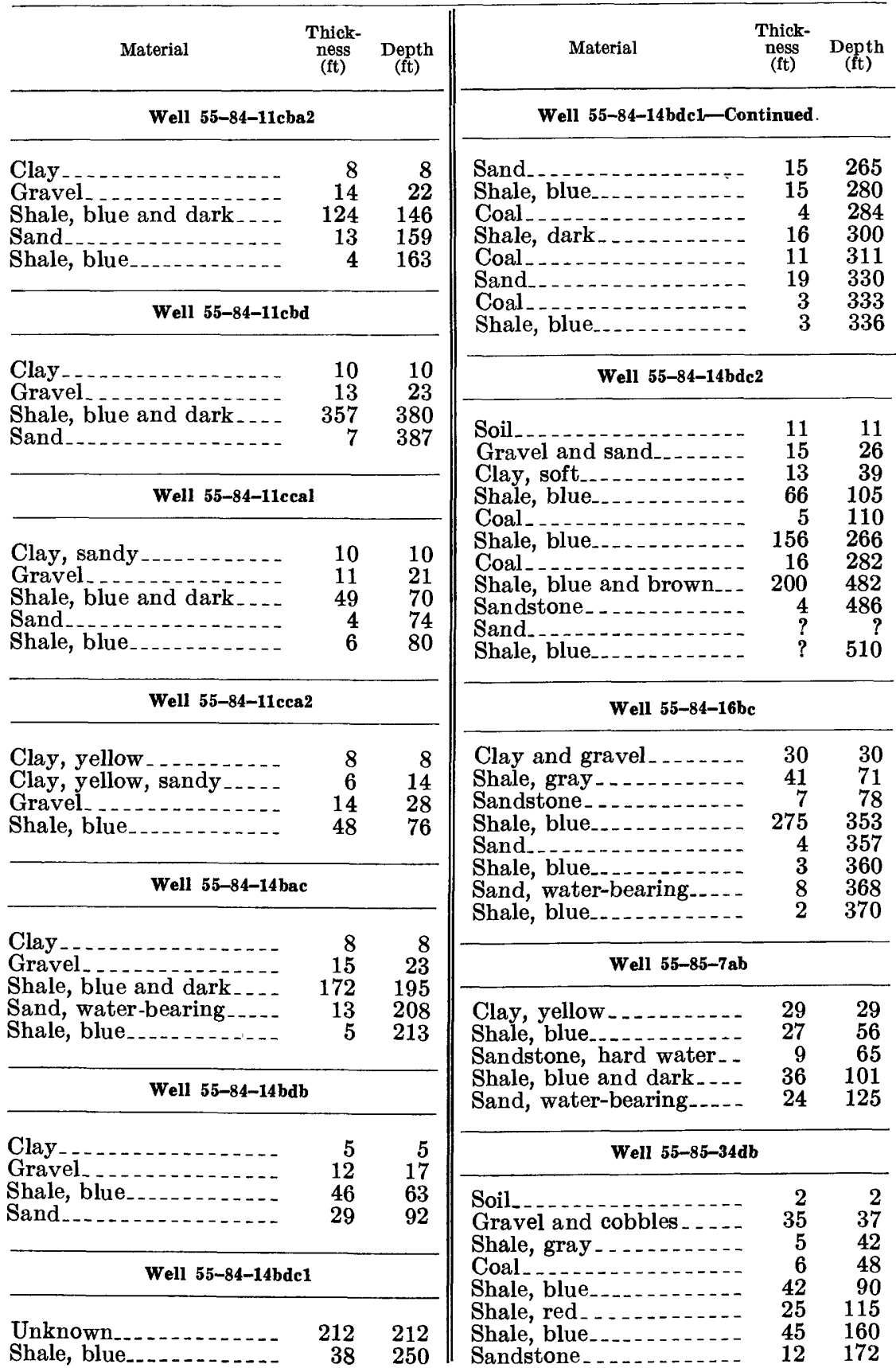


TABLE 7.-Logs of test holes, seismic shotholes, and wells-Continued DRILLERS' LOGS-Continued

\begin{tabular}{|c|c|c|}
\hline Material & $\begin{array}{c}\text { Thick- } \\
\text { ness } \\
\text { (ft) }\end{array}$ & $\begin{array}{c}\text { Depth } \\
\text { (ft) }\end{array}$ \\
\hline \multicolumn{3}{|l|}{ Well 55-89-1da } \\
\hline $\begin{array}{l}\text { Soil } \\
\text { Sandy soil } \\
\text { Sandstone } \\
\text { Rock (quartzite?) } \\
\text { Sandstone, water-bearing } \\
\text { Granite, decomposed.-- }\end{array}$ & $\begin{array}{r}2 \\
6 \\
24 \\
22 \\
4 \\
8\end{array}$ & $\begin{array}{r}2 \\
8 \\
32 \\
54 \\
58 \\
66\end{array}$ \\
\hline \multicolumn{3}{|l|}{ Well $56-77-3 \mathrm{db}$} \\
\hline $\begin{array}{l}\text { Soil } \\
\text { Gravel } \\
\text { Shale } \\
\text { Coal } \\
\text { Shale } \\
\text { Coal } \\
\text { Shale } \\
\text { Coal } \\
\text { Shale } \\
\text { Sand } \\
\text { Shale } \\
\text { Sand } \\
\text { Coal } \\
\text { Shale } \\
\text { Sand } \\
\text { Coal } \\
\text { Sand } \\
\text { Shale } \\
\text { Sand } \\
\text { Coal } \\
\text { Sand } \\
\text { Shale } \\
\text { Coal } \\
\text { Shale.. } \\
\text { Sand, water-bearing } \\
\text { Shale. }\end{array}$ & $\begin{array}{r}30 \\
5 \\
3 \\
5 \\
38 \\
4 \\
5 \\
13 \\
9 \\
4 \\
16 \\
26 \\
9 \\
52 \\
41 \\
12 \\
2 \\
112 \\
8 \\
16 \\
20 \\
10 \\
55 \\
19 \\
21 \\
15\end{array}$ & $\begin{array}{r}30 \\
35 \\
38 \\
43 \\
81 \\
85 \\
90 \\
103 \\
112 \\
116 \\
132 \\
158 \\
167 \\
219 \\
260 \\
272 \\
274 \\
386 \\
394 \\
410 \\
430 \\
440 \\
495 \\
514 \\
535 \\
550\end{array}$ \\
\hline
\end{tabular}

\section{Well 56-79-24dd}

Soil

Sandstone, yellow

Shale, blue

Sandstone

Shale, blue

Sandstone . . . .........

Shale, blue

Coal

Shale, blue

Sand, water-bearing

Shale, blue

\begin{tabular}{|c|c|c|}
\hline Material & $\begin{array}{l}\text { Thick- } \\
\text { ness } \\
\text { (ft) }\end{array}$ & $\begin{array}{l}\text { Depth } \\
\text { (ft) }\end{array}$ \\
\hline \multicolumn{3}{|l|}{ Well 56-81-29bd } \\
\hline Clay & 6 & 6 \\
\hline Gravel, composed of clink- & & \\
\hline Shale, blue & $\begin{array}{l}30 \\
32\end{array}$ & $\begin{array}{l}36 \\
68\end{array}$ \\
\hline Coal & 1 & 69 \\
\hline Shale, blue & 36 & 105 \\
\hline Sand, water seep. & 15 & 120 \\
\hline Shale, blue. . . . . & 50 & 170 \\
\hline Sand, water seep. & 7 & 177 \\
\hline Shale, blue...... & 43 & 220 \\
\hline Sandstone. ..... & 9 & 229 \\
\hline Shale, blue & 103 & 332 \\
\hline
\end{tabular}

Well 56-84-34da

Soil _.

Sand and gravel_......

Shale, gray .......... $22 \quad 40$

Shale, blue............ $70 \quad 110$

Sandstone, water seep..- $\quad 10 \quad 120$

Shale, blue_._._. . _._. $115 \quad 235$

Sandstone, brown, dry - - $\quad 17 \quad 252$

Shale, blue_..._....... $36 \quad 38$

Coal__.............. $24 \quad 312$

Sand, water seep. ..... $4 \quad 4 \quad 316$

Shale, blue........... $132 \quad 448$

$\begin{array}{lrr}\text { Coal } & 9 & 457\end{array}$

Shale, blue........... $53 \quad 510$

Sand, water-bearing ..... $\quad 35 \quad 545$

Shale.............. 5550

Well 56-86-7dc

Gravel $\ldots \ldots \ldots$

Shale, dark

Bentonite.......... 395

Shale, dark . . . . . . . . $40 \quad 135$

Sand, water-bearing...-. $\quad 4 \quad 139$

Shale, dark $\ldots \ldots \ldots$. 148

Well 57-79-25cb

Clay _...

Shale, blue.......... 94

Sand, water-bearing-...- $11 \quad 54$

Shale, blue_............ $22 \quad 76$

Sand, water-bearing....- $\quad 11 \quad 87$

Shale, blue._._._.... 89 
TABLE 7.-Logs of test holes, seismic shotholes, and wells-Continued DRILLERS' LOGS-Continued

\begin{tabular}{|c|c|c|}
\hline Material & $\begin{array}{c}\text { Thick- } \\
\text { ness } \\
\text { (ft) }\end{array}$ & $\underset{\text { (ft) }}{\text { Depth }}$ \\
\hline \multicolumn{3}{|l|}{ Well 57-80-31bb } \\
\hline Soil__.... & 15 & 15 \\
\hline Gravel_............... & 30 & 45 \\
\hline Coal _... & 5 & 50 \\
\hline Shale, blue $\ldots \ldots \ldots$ & 75 & 125 \\
\hline Sand, water-bearing & 10 & 135 \\
\hline Shale, blue $\ldots \ldots \ldots$ & 5 & 140 \\
\hline Sand, water-bearing & 10 & 150 \\
\hline Shale, blue $\ldots \ldots \ldots$ & 10 & 160 \\
\hline
\end{tabular}

\section{Well 57-81-7cb}

Clay, yellow, and gravel.--

Clay, yellow

Shale, blue

Sand, water.

Sandstone

Shale, blue . . . . . . . . . .

Sandstone. . . . . . . . .

Shale, blue . . . . .......

Sand, hard water .......

Shale, blue and dark

Sand...................

Shale, blue ............

Sand ................

Shale, blue

Coal, soft water.......

Shale . . . . . . . . . . . .

Sand

Shale, blue ...........

Sandstone

Shale, blue

Sand, soft water........

Clay, dark ..............

Sandstone

Shale, blue
Shale, blue

\begin{tabular}{|c|c|c|}
\hline Material & $\begin{array}{l}\text { Thick- } \\
\text { ness } \\
\text { (ft) }\end{array}$ & $\underset{\text { Depth }}{\text { (ft) }}$ \\
\hline \multicolumn{3}{|c|}{ Well 57-84-19bd-Continued } \\
\hline Shale, blue & 21 & 60 \\
\hline Coal $\ldots \ldots$ & 3 & 63 \\
\hline Shale, blue & 22 & 85 \\
\hline Coal & 7 & 92 \\
\hline Shale, blue $\ldots$ & 13 & 105 \\
\hline Sandstone $\ldots$ & 7 & 112 \\
\hline Shale, blue & 8 & 120 \\
\hline Coal, water-bearing. -.. & 6 & 126 \\
\hline
\end{tabular}

\section{Well 57-85-19ab}

Soil_._. _............ 44

Sand and gravel $\ldots$

Shale, blue _........... 2

Sand and coarse gravel-- $\quad 10 \quad 24$

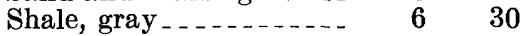

\begin{tabular}{lrr}
\hline \multicolumn{3}{c}{ Well 57-86-9ab } \\
\hline \\
Clay, sandy & 5 & 5 \\
Gravel & 14 & 19 \\
Shale, blue & & \\
\hline
\end{tabular}

Well 57-86-30ac

Soil_._.............. 55

Gravel and sand

Sandstone, water-bearing_ $\quad 25 \quad 55$

Shale, blue.......... 257

Sandstone............ 85

Limestone $\ldots \ldots \ldots$. . . . 38

Shale, brown $\ldots . \ldots 37 \quad 105$

Limestone.......... 207

Sand, flow . . . . .

\section{Well 57-86-34bb}

Soil, sandy shale and

gravel_........... $50 \quad 50$

Sandstone, gray . . . . $\quad 20 \quad 70$

Shale, gray _......... $40 \quad 110$

Shale, brown, sandy .... $40 \quad 150$

Shale, gray . . . . . . . . $40 \quad 190$

Shale, brown

Clay, yellow $\ldots . . . . . . . .69$

Clay, sandy

Gravel_................ $5 \quad 5$

Shale, blue............ $17 \quad 36$

Sandstone............ 39
Shale, gray _......... $60 \quad 300$

Sandstone, gray, waterbearing

Shale, gray $\ldots$ 
TABLE 7.-Logs of test holes, seismic shotholes, and wells-Continued DRILLERS' LOGS-Continued

\begin{tabular}{|c|c|c|c|c|c|}
\hline Material & $\begin{array}{l}\text { Thick- } \\
\text { ness } \\
\text { (ft) }\end{array}$ & $\begin{array}{l}\text { Depth } \\
\text { (ft) }\end{array}$ & Material & $\begin{array}{c}\text { Thick- } \\
\text { ness } \\
\text { (ft) }\end{array}$ & $\underset{\text { (ft) }}{\text { Depth }}$ \\
\hline \multicolumn{3}{|l|}{ Well 58-76-30ce } & \multicolumn{3}{|l|}{ Well 58-82-30aa } \\
\hline .......... & 15 & 15 & Soil _........ & 10 & 10 \\
\hline Shale & 15 & 30 & Gravel, red clinker & 10 & 20 \\
\hline (n) & 8 & 38 & Shale. & 40 & 60 \\
\hline$\ldots \ldots$ & 27 & 65 & Coal _. - & 10 & 70 \\
\hline$\ldots$ & 18 & 83 & Shale . . ... & 160 & 230 \\
\hline - & 25 & 108 & Coal, gas . & 10 & 240 \\
\hline - & 2 & 110 & Shale _... & 40 & 280 \\
\hline 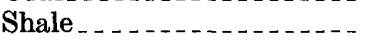 & 26 & 136 & Coal _- & 10 & 290 \\
\hline$\ldots \ldots \ldots \ldots$ & 11 & 147 & Shale _ & $\begin{array}{l}90 \\
10\end{array}$ & $\begin{array}{l}380 \\
390\end{array}$ \\
\hline Shale $_{\text {_ }} \ldots$ & 86 & 233 & Shale. & 10 & 400 \\
\hline Coal, water-bearing & 27 & 260 & Sand & 40 & 440 \\
\hline Shale_ $\ldots \ldots$ & 10 & 270 & $\begin{array}{l}\text { Coal, flow } \\
\text { Shale }\end{array}$ & $\begin{array}{l}30 \\
10\end{array}$ & $\begin{array}{l}470 \\
480\end{array}$ \\
\hline \multicolumn{3}{|l|}{ Well 58-81-20ad } & \multicolumn{3}{|l|}{ Well $58-87-35 \mathrm{ca} 2$} \\
\hline Clay $_{\ldots} \ldots$ & 35 & 35 & Soil_....... & 4 & 4 \\
\hline Shale, blue $\ldots \ldots$ & 55 & 90 & Shale, gray $\ldots \ldots$ & 31 & 35 \\
\hline Sand & $\mathbf{5}$ & 95 & Sandstone, brown & 2 & 37 \\
\hline Shale, blue ........... & 10 & 105 & Shale, gray $\ldots$ & 23 & 60 \\
\hline Sand, water seep & 7 & 112 & Sand, water-bearing & 5 & 65 \\
\hline Shale, blue and dark & 163 & 275 & Sandstone, gray $\ldots \ldots$ & 35 & 100 \\
\hline Sand, water-bearing ...... & 8 & 283 & Sandstone, gray & 10 & 115 \\
\hline Shale, blue $\ldots \ldots$ & 7 & 290 & Sand, water-bearing & 5 & 120 \\
\hline Sand, water-bearing $\ldots$ & 4 & 294 & Sandstone, gray & 8 & 128 \\
\hline Shale, blue $\ldots \ldots$ & 2 & 296 & Shale $\ldots \ldots$ & 1 & 129 \\
\hline
\end{tabular}





\section{INDEX}

[Italic page numbers indicate major references]

A

Acknowledgments

Acme, water supply

Agriculture, chemical quality of water for-..-

Alluvium, analyses of water from ............. water-bearing properties. wells in, specific capacity.

Altitudes

Amsden Formation, analyses of water from features. water-bearing properties

Analyses, gas See also Chemical analyses.

Aquifers, field tests. gas content. hydraulic properties pre-Tertiary

Quaternary

Tertiary

Artesian conditions

Arvada, discharge at.

rainfall at

water supply

B

Basic data

ing properties

Big Horn, water supply .........................

Bighorn Dolomite, features.................. water-bearing properties.

Bighorn Mountains

Page

\section{C}

Calcium bicarbonate type, definition

Carbon dioxide

Cation-exchange softening .

Cattle. See Stock-water supplies.

Cave Creek

Chemical analyses

Chemical-quality data, how reported

Chugwater Formation, water-bearing properties.

Clear Creek.

Clearmont, rainfall at

water supply

Climate

Cloverly Formation, water-bearing properties.

Coal

Coal-bearing beds, section

Cody Shale, water-bearing properties

Coefficients. See Permeability; Storage; Transmissibility.

Cones of depression 40,46

Page

Discharge, from pre-Tertiary rocks from Quaternary deposits. . ............ 51

Domestic water supplies, chemical quality _.. 23 rural areas.............................. 22

Drainage......... 5

Drinking-water standards ................... 23

Duncom Mountain ........................ 28

F

Flathead Sandstone, analyses of water from. - $\quad 30$ water-bearing properties................. 13

Flood-plain deposits, features.......... 50 water-bearing properties.............. 10

Fort Union Formation, analyses of water from. 30,44 aquifer test............................... 20

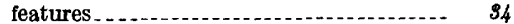
gas in water from section . . . use of water from...................... 45 water-bearing properties............... 10, $\$ 9,51$ wells in, specific capacity ................ 21

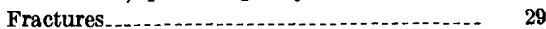

Frontier Formation, analyses of water from - - $\quad 30$ water-bearing properties................. 11

\section{G}

Gallatin and Gros Ventre Formations, undifferentiated, water-bearing properties.

Gas ..................... 14, 46,47

Geography . .............................. 5

Geology and water resources............. 26

Goose Creek ........... 8

Gros Ventre and Gallatin Formations, undifferentiated, water-bearing properties........ 13

Ground water, chemical quality ...... 25,30

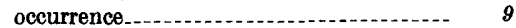
utilization .............................. 22

Gypsum Spring Formation, water-bearing properties....................... 12

\section{H}

Hardness, cause

\section{I}

Industry, chemical quality of water for .......

Introduction

Investigations

Irvestigations...............

water supplies, chemical quality 
Joints

to Quaternary deposits . . . .

to Tertiary rocks......................... 42

Kingsbury Conglomerate Member

water-bearing properties.

\section{$\mathbf{L}$}

Lance Formation, analyses of water from.... water-bearing properties..................

Land slumps.

Landforms

Landslide deposits, water-bearing properties..

Landslides.

Leaky Mountain Spring.

Lebo Shale Member.

Little Bighorn River

Little Tongue River.

Logs.

\section{M}

Madison Limestone, features water-bearing properties

Methane

Methods of investigation

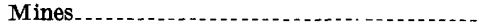

Monarch, water supply

Moncrief Member, features.

water-bearing properties

Morrison Formation, water-bearing properties.

Mowry Shale, water-bearing properties Municipal water supplies.

$N$

Newcastle Sandstone, water-bearing properties...-.

Nonequilibrium methods

\section{$\mathbf{P}$}

Parkman, rainfall at

Parkman Sandstone, analyses of water from. water-bearing properties

P ermeability, coefficient, definition ..........

P iedmont deposits, water-bearing properties -

$P$ iezometric surface. See Water level.

P orosity, definition

$P$ owder River

$P$ owder River structural basin.

$P$ re-Tertiary rocks, general features. quality of water from wells in

Preacher Rock.

Precipitation Pumping tests. See Wells.

Purpose and scope.

\section{Q}

Quaternary deposits, general features quality of water from
Red shale and gypsum sequence, water-bearing properties..................... 12

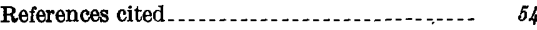

Retention. See Specific retention.

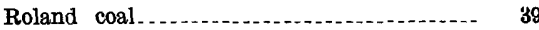

S

Saline water, use........... 24

Seismic shotholes, logs....................... 66

Sheep. See Stock-water supplies.

Sheridan, rainfall at........................ 8

Sheridan County, location and extent....... 2

Skull Creek Shale, water-bearing properties_. 11

Slumps. See Land slumps.

Sodium-adsorption-ratio, definition......... 25

Sodium-calcium bicarbonate type, definition.- $\quad 23$

Sodium sulfate bicarbonate type, definition.- 23

Soil, effect of saline water on ............... 25

South Piney Creek........................... 29

Specific capacity, definition............... 21

Specific conductance, definition ............. 23

Specific retention, definition.............. 20

Specific yield, definition

Spotted Horse coal field . . . . . . . . . . . .

Springs

records

Stock-water supplies......................... 22

chemical quality

Storage, coefficient, definition............ 20

Story, water supply . .

Stratigraphic section

Stratigraphy, summary

Sulfate reduction............................. 45

Sundance Formation, water-bearing proper-

ties

$\mathrm{T}$

Tensleep Sandstone, analyses of water from $\quad 31$

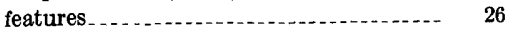
water-bearing properties............. 12, 27

Terrace deposits, features_._._._._._._._. $\quad 50$ water-bearing properties................ 10, 51

Tertiary rocks, general features.............. $\$ 4$ quality of water from wells in

Test holes, logs. ............ 66

Tongue River . . .

Tongue River Cave. . . .

Tongue River Member

Transmissibility, coefficient, definition..... 17

Tubular openings. .............. 29

Tullock Member .............. 34

\section{$\mathrm{U}$}


Wasatch Formation, analyses of water from.- 32,49 aquifer test.

features.

section.

use of water from

water-bearing properties

wells in, specific capacity

Water-bearing materials. See Aquifers.

Water levels, effect of gas on fluctuations .

Water-quality criteria. See Ground water, 1 chemical quality.

We $\mathrm{s}$, in pre-Tertiary rocks

Wells-Continued

in Tertiary rocks . . . . . . . . . . 39,50

yields . . . .

interference between

logs

numbering system...................... 5

pumping tests............................ 20

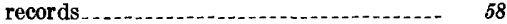

specific capacity

water levels in

White River Formation, water-bearing proper-

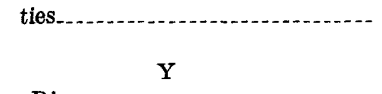

in Quaternary deposits. 